UNIVERSIDADE DE SÃO PAULO

PROGRAMA DE PÓS-GRADUAÇÃO INTERUNIDADES EM ESTÉTICA E HISTÓRIA DA ARTE

MARIANA PEREIRA LENHARO

Van Gogh e a melancolia: Pinturas de pôr do sol em Arles

São Paulo

Julho de 2014 
Van Gogh e a melancolia: Pinturas de pôr do sol em Arles

Dissertação apresentada ao Programa de Pós-Graduação Interunidades em Estética e História da Arte da Universidade de São Paulo para obtenção do título de Mestre em Estética e História da Arte

Linha de pesquisa: Teoria e Crítica da Arte

Orientadora: Profa. Dra. Katia Canton 
AUTORIZO A REPRODUÇÃO E DIVULGAÇÃO TOTAL E PARCIAL DESTE TRABALHO, POR QUALQUER MEIO CONVENCIONAL OU ELETRÔNICO, PARA FINS DE ESTUDO E PESQUISA, DESDE QUE CITADA A FONTE.

Catalogação da Publicação

Biblioteca Lourival Gomes Machado

Museu de Arte Contemporânea da Universidade de São Paulo

Lenharo, Mariana Pereira.

Van Gogh e a melancolia: pinturas de pôr do sol em Arles / Mariana Pereira Lenharo ; orientadora Katia Canton. -- São Paulo, 2014.

$118 \mathrm{f.}$ : il.

Dissertação (Mestrado - Programa de Pós-Graduação Interunidades em Estética e História da Arte) -- Universidade de São Paulo, 2014.

1. Pós-impressionismo. 2. Arte Moderna - Século 19. 3. Melancolia. 4. Van Gogh, Vincent, 1853-1890. I. Canton, Katia. II. Título.

CDD 759.056 
LENHARO, Mariana Pereira

Van Gogh e a melancolia: Pinturas de pôr do sol em Arles

Dissertação apresentada ao Programa de Pós-Graduação Interunidades em Estética e História da Arte da Universidade de São Paulo para obtenção do título de Mestre em Estética e História da Arte

Linha de pesquisa: Teoria e Crítica da Arte

Aprovado em:

Banca examinadora

Prof. Dr. Instituição:

Julgamento: Assinatura:

Prof. Dr. Instituição:

Julgamento: Assinatura:

Prof. Dr. Instituição:

Julgamento: Assinatura: 


\section{AGRADECIMENTOS}

À professora Katia Canton, que acreditou em minha proposta e me deu a oportunidade de desenvolver esta pesquisa.

À professora Elza Ajzenberg e ao professor Paulo Roberto Barbosa, pelas importantes contribuições na banca de qualificação.

Aos colegas de mestrado Alex Gomes, Adriana D'Agostino e Aryane Cararo, pela ajuda ao longo do desenvolvimento do trabalho e pelo apoio nos momentos difíceis.

Ao Daniel, pela revisão do trabalho.

Aos meus amigos, pelo carinho e companheirismo.

À minha família, por todo apoio e incentivo. 
Enfim, quero chegar ao ponto em que digam de minha obra: este homem sente profundamente, este homem sente delicadamente. Apesar de minha suposta grosseria, você me entende? Ou precisamente por causa dela.

Vincent van Gogh, 1882 


\section{RESUMO}

Este trabalho tem por objetivo verificar que tipo de impacto as crises de melancolia do pintor Vincent van Gogh podem ter exercido sobre sua produção artística. Os questionamentos tomados como ponto de partida são os seguintes: se o estado de melancolia impulsiona seu trabalho como artista, se a melancolia imprime características específicas em sua obra e se a arte proporciona a Van Gogh um alívio ou um agravamento de sua natureza melancólica. A pesquisa foca um período específico na vida do artista: os primeiros 10 meses em que viveu na cidade de Arles, no sul da França, entre fevereiro e dezembro de 1888. A leitura das 139 cartas escritas por Van Gogh neste período possibilitou identificar os momentos em que ele descrevia seu próprio estado de espírito como melancólico. A partir desta identificação, o trabalho parte para a análise de obras produzidas no período, das quais foram selecionadas oito telas de pôr do sol. A observação das telas sob o contexto do sentimento experimentado por Van Gogh enquanto as produzia levou, por fim, a uma reflexão sobre a relação entre melancolia e a arte no pintor.

Palavras-chave: Vincent van Gogh, Melancolia, Arte Moderna. 


\begin{abstract}
The aim of this research is to verify what kind of impact the melancholy crises of the painter Vincent van Gogh may have had in his artistic production. The questions that represent the starting point are: whether the state of melancholy impels his work as an artist, whether melancholy results in specific features in his work and whether art provides a relief or an aggravation of Van Gogh's melancholy nature. The research focuses on a specific period in the artist's life: the first 10 months in which he lived in the city of Arles, in the south of France, between February and December of 1888 . The reading of the 139 letters written by Van Gogh during this period enabled the identification of the moments in which he described his own state of mind as melancholic. Based on this identification, the study starts the analysis of the paintings produced in this period, from which eight canvas of setting suns were selected. The observation of these works under the context of the emotions experimented by Van Gogh while he painted them led, ultimately, to a reflection about the relationship between melancholy and art in the painter.
\end{abstract}

Keywords: Vincent van Gogh, Melancholy, Modern Art. 


\section{LISTA DE FIGURAS}

Figura 1 - Vincent van Gogh, Pollard willows with setting sun ( 572 / JH 1597), março de 1888, óleo sobre tela - 31,6 x 34,3 cm. Kröller-Müller Museum, Otterlo, Holanda 77

Figura 2 - Vincent van Gogh, Sower with setting sun (F422 / JH 1470), junho de 1888, óleo sobre tela $-64,2$ x 80,3 cm. Kröller-Müller Museum, Otterlo, Holanda 82

Figura 3 - Vincent van Gogh, Wheatfield with setting sun (F 465 / JH 1473), junho de 1888, óleo sobre tela $-74 \times 91 \mathrm{~cm}$, Kunstmuseum Winterthur, Winterthur, Suíça ...... 86

Figura 4 - Fac-símile da Carta 628, escrita em 19 de junho para Emile Bernard, com esboço do quadro Wheatfield with setting

Figura 5 - Vincent van Gogh, Sunset at Montmajour (F - / JH -), julho de 1888, óleo sobre tela - 93,3 x 73,3 cm. Coleção privada

Figura 6 - Vincent van Gogh, Sand barges (F437 / JH 1570), outubro de 1888, óleo sobre tela $-71 \times 95 \mathrm{~cm}$. Coleção privada.

Figura 7 - Vincent van Gogh, Sand barges (F438 / JH 1571), outubro de 1888, óleo sobre tela - 53,3 x $64 \mathrm{~cm}$. Museu Thyssen-Bornemisza, Madri, Espanha.....

Figura 8 - Vincent van Gogh, Red vineyard (F495 / JH 1626), novembro de 1888, óleo sobre tela $-75 \times 93 \mathrm{~cm}$. Pushkin State Museum of Fine Arts, Moscou, Rússia 96

Figura 9 - Paul Gauguin, Human miseries (W317/W304), novembro de 1888, óleo sobre tela - 73,5 x 92,5 cm. Ordrupgaard Collection, Copenhague, Dinamarca..... 97

Figura 10 - Vincent van Gogh, Sower with setting sun (F450 / JH 1627), novembro de 1888, óleo sobre estopa sobre tela $-73,5$ x $93 \mathrm{~cm}$. Foundation E. G. Buehrle Collection, Zurique, Suíça 99

Figura 11 - Fac-símile da carta 722, escrita para Theo em 21 de novembro de 1888, com esboço da pintura Sower with setting sun 101

Figura 12 - Vincent van Gogh, Doctor Gachet (F 753 / JH 2007), 1890, óleo sobre tela $66 \times 57 \mathrm{~cm}$. Coleção privada..... 105

Figura 13 - Vincent van Gogh, Sorrow (929a / JH 130), 1882, carvão - 44,5 x 27 cm. Walsall Museum and Art Gallery, The Garman Ryan Collection, Walsall, Inglaterra ... 106

Figura 14 - Vincent van Gogh, At Eternity's gate (F702 / JH1967), 1890, óleo sobre tela 
Figura 15 - Vincent van Gogh, Weeping woman (F1069 / JH325), giz preto e branco sobre papel, 1883, Art Institute of Chicago, Chicago, Estados Unidos.....

Figura 16 - Vincent van Gogh, Peasant sitting by the fireplace (F863 / JH34), aquarela, 1881. P. and N. de Boer Foundation, Amsterdam, Holanda... 


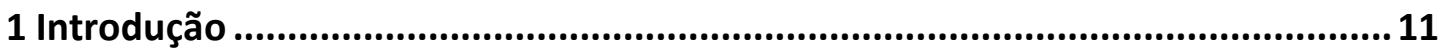

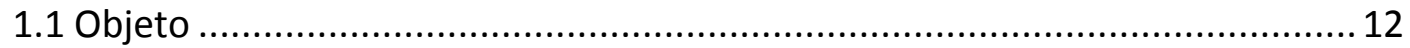

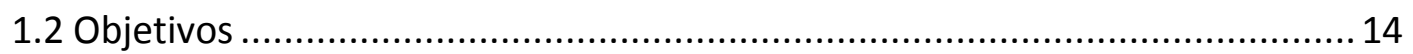

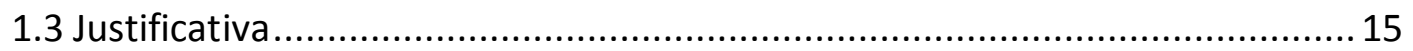

1.4 Metodologia e quadro teórico de referência ............................................. 16

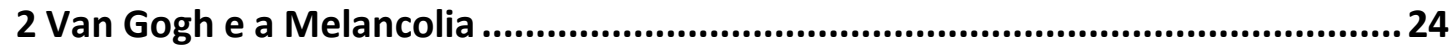

2.1 Evolução histórica do conceito de melancolia ................................................ 24

$2.2 \mathrm{O}$ artista se define como melancólico ...................................................... 35

2.3 Jornada até o sul da França ......................................................................... 40

3 A produção nos períodos melancólicos .............................................................47

3.1 As cartas revelam seus sentimentos .................................................... 47

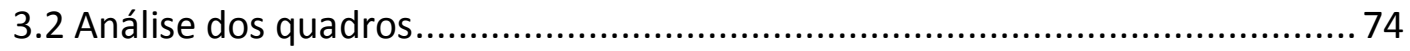

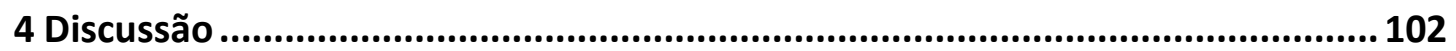

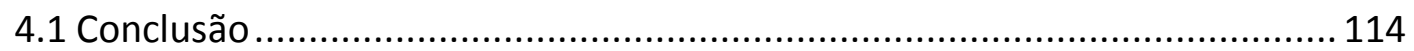

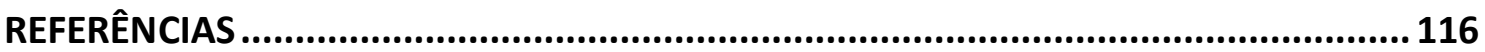


1 Introdução

A melancolia é uma característica marcante da personalidade de Vincent van Gogh (1853 - 1890). Descrito por seus biógrafos e por sua própria família como aquele que estava sempre "no limiar da melancolia" (SWEETMAN, 1993, p. 80) e que alimentava "hábitos de solidão e de melancolia" desde a infância (NAIFEH e SMITH, 2012, p. 129), o artista também costumava mencionar em suas cartas como sua natureza era "terrivelmente e irreparavelmente melancólica" (Carta 244) ${ }^{1}$.

Mas de que forma este temperamento reflete em suas obras de arte? Foi esta a pergunta que me fez delinear o projeto de mestrado que resultou nesta dissertação. Cabe mencionar aqui algumas das principais motivações que me levaram a escolher tratar do sentimento de melancolia no artista Vincent van Gogh.

Primeiro, assim como deve ser em qualquer processo de pesquisa, o que me guiou foi a curiosidade. As pinturas de Van Gogh passaram a exercer fascínio sobre mim desde cedo. A ideia de que eram produzidas por uma espécie de gênio-louco, no entanto, sempre foi motivo de desconfiança por parecer uma constatação demasiado simplista. Descobrir o homem por trás da arte é, portanto, minha principal intenção. E tentar identificar algo que tenha passado despercebido por inúmeros olhares anteriores é meu desafio.

Hoje, aliás, todos os olhares voltam-se para Van Gogh. Seus quadros atingem preços exorbitantes em leilões de $\operatorname{arte}^{2}$ e, em pleno ano de 2012, um livro que se propôs, mais uma vez, a contar a história de sua vida turbulenta ganhou uma imensa projeção midiática $^{3}$. A descoberta de uma nova tela do artista em 2013 também foi noticiada com destaque por veículos de comunicação do mundo inteiro. Ainda assim, vejo espaço para revelar o novo.

\footnotetext{
${ }^{1}$ As menções às cartas escritas por Van Gogh neste trabalho seguem sempre a numeração proposta pela publicação mais recente e mais completa da correspondência do artista: VAN GOGH, Vincent. The letters. The complete illustrated and annotated edition. Londres: Thames \& Hudson, 2009.

${ }^{2} \mathrm{O}$ quadro "Vue de l'Asile et de la Chapelle de Saint-Remy" que pertencia à coleção da atriz Elizabeth Taylor, foi vendido na casa de leilão Christie's em fevereiro de 2012 por US\$ 16 milhões. Em 1987, um de seus "Les Tournesols" bateu um recorde no mercado da arte ao ser leiloado por US\$ 36 milhões.

${ }^{3}$ Este livro é "Van Gogh: A vida", de Steven Naifeh e Gregory White Smith. Lançado no Brasil em novembro de 2012 pela Companhia das Letras, propôs um novo olhar sobre a morte de Van Gogh, contestando a tese de morte do pintor como suicídio.
} 
Ao longo deste trabalho, busco descobrir de que maneira os diferentes estados de espírito experimentados por Van Gogh podem ter influenciado sua produção artística. Em sua trajetória marcada por oscilações frequentes entre melancolia e euforia, seria possível detectar em sua pintura sinais da presença desses sentimentos?

É como se ele fosse duas pessoas: uma maravilhosamente dotada, terna e refinada, a outra egoísta e cruel. Elas se apresentam alternadamente, de modo que a gente o ouve falar primeiro de uma maneira, depois da outra, e sempre com discussões dos dois lados. (VAN GOGH, Theo apud SWEETMAN, 1993, p. 195)

A descrição feita por Theo van Gogh, irmão de Vincent, em carta enviada à irmã Willemien, demonstra quão nítida era sua percepção sobre a dualidade do espírito do artista. Este trabalho busca conhecer mais profundamente essas duas pessoas: o bom e o cruel, o melancólico e o eufórico, o sensato e o desvairado, o monge e o pintor.

Esta pesquisa aborda um período específico da vida de Van Gogh - os dez primeiros meses em que viveu em Arles, no sul da França - para buscar identificar de que forma os episódios de melancolia, que eram intercalados com momentos de euforia, interferiram em sua produção artística.

A partir das cartas escritas na época, foi possível determinar os períodos em que ele mencionou estar se sentindo melancólico. A partir daí, escolhi um tema de pintura que se repetiu ao longo de todo o período analisado: o pôr do sol. O trabalho parte, então, para a análise das oito telas de pôr do sol produzidas nesses 10 meses, levando em conta que algumas delas foram feitas em meio a crises de melancolia e outras não.

\subsection{Objeto}

Este estudo tem como objeto as pinturas produzidas por Van Gogh entre fevereiro e dezembro de 1888 e também as cartas escritas pelo artista na mesma época. O período de 10 meses delimitado por este estudo vai desde sua mudança de Paris - onde vivera por quase três anos com o irmão Theo - para a cidade de Arles, no sul da França, até a crise que o leva à automutilação da orelha. 
A escolha por esse período específico deve-se ao fato de que, em Arles, Van Gogh experimentou estados de espírito muito distintos em um curto intervalo de tempo. Se houve momentos em que demonstrou intenso entusiasmo com o clima e as cores quentes do sul, características que o aproximavam do Japão que tanto admirava, houve também situações em que se sentiu solitário e melancólico. Foi nessa época que ele começou a sonhar, esperançoso, com a formação de uma comunidade de artistas, ambição que foi amplamente documentada em sua correspondência e que tomou conta de boa parte de sua reflexão sobre a arte no período. Foi lá também que percebeu sinais de que sua idealização poderia jamais ser concretizada.

Nos meses que se seguem ao fatídico incidente da orelha, ocorrido em 23 de dezembro de 1888, o pintor passa longos períodos internado em busca da recuperação mental. Suas cartas tornam-se mais escassas e seu trabalho, mais irregular. Por esse motivo, este estudo limita-se à fase que antecede a crise.

O psiquiatra Humberto Nagera, que dedicou ao pintor um estudo psicológico publicado pela primeira vez no final da década de 1960, afirma que o período de Arles tem uma importância primordial na vida de Van Gogh, tanto do ponto de vista artístico - pois é quando atinge sua forma de expressão mais acabada -, quanto do ponto de vista psicológico:

[Em Arles] sua vida e seus conflitos psicológicos alcançam também um ponto culminante, o qual, por desgraça, marca o começo de um período infeliz e de grandes perturbações que conduzem, quase sem interrupção, ao final ocorrido um ano e dois meses mais tarde, em julho de 1890. (...) Às vezes, queixa-se de seu nervosismo e ansiedade. Está, em alguns momentos, animado e, em outros, deprimido. Seu isolamento e sua solidão não contribuem para aliviá-lo. (NAGERA, 1980, p. 113, tradução nossa)

Por condensar muitas experiências discrepantes, a análise dessa fase permitirá observar possíveis contrastes entre as pinturas produzidas em momentos de melancolia e em momentos de euforia e identificar se, afinal, a presença desses sentimentos foi capaz de provocar um impacto perceptível em sua obra.

Levando em conta toda a estadia em Arles, que se estendeu por mais quatro meses após o episódio de automutilação, até o dia 8 de maio de 1889, Van Gogh 
produziu mais de 200 quadros e mais de 100 desenhos e aquarelas (PICKVANCE, 1985, p. 11).

Do período analisado, chegaram até nós 139 cartas escritas por Van Gogh. A maioria delas, 106, tinha como destinatário o irmão Theo. 0 segundo maior correspondente da época foi o pintor francês Emile Bernard, para quem escreveu 19 cartas. Sua irmã Willemien foi a destinatária de 8 correspondências. Outros amigos com quem trocou cartas ao longo dos 10 meses foram o pintor de origem australiana John Peter Russell, o belga Eugène Boch, o holandês Arnold Koning, além de Paul Gauguin.

A frequência com que Van Gogh escrevia a amigos e familiares variou durante os meses em que esteve em Arles. Em março, por exemplo, escreveu apenas 8 cartas. Já em outubro, chegou a enviar 20 correspondências. Ao longo dos 10 meses analisados, o artista escreveu, em média, uma carta a cada dois dias.

Ele tinha uma necessidade real de trocar ideias, de discutir problemas artísticos e comparar seu trabalho com o de outros artistas, de preferência pessoalmente, senão por carta. Se ele pudesse falar com as pessoas face a face, ele obviamente teria menos necessidade de escrever. (JANSEN; LUIJTEN; BAKKER, 2009, tradução nossa)

$\mathrm{Na}$ edição mais recente e mais completa das cartas, os editores ressaltam ainda outro aspecto da correspondência: a qualidade intrínseca da escrita de Vincent. “(...) tom pessoal, estilo evocativo e linguagem viva. A combinação desses fatores levou alguns especialistas a conceder à correspondência o status de literatura." (JANSEN; LUIJTEN; BAKKER, 2009).

Desta forma, o conjunto formado pela correspondência e pelas pinturas realizadas no período, bem como a documentação que permite determinar com precisão a data em que as pinturas foram executadas, servem como base para a execução desta pesquisa.

\subsection{Objetivos}


Este trabalho tem como objetivo geral identificar se o estado de melancolia experimentado pelo pintor Vincent van Gogh em determinados períodos de sua vida teve algum impacto em sua produção artística.

Como objetivos específicos, pretende, primeiro, identificar se o estado de melancolia em Vincent van Gogh impulsiona ou inibe sua produtividade artística.

Em segundo lugar, pretende identificar se existem características presentes nas obras produzidas em períodos de melancolia que diferem daquelas presentes em obras relacionadas a períodos de euforia ou de serenidade.

Finalmente, pretende identificar se a produção artística tem algum efeito sobre seu estado de espírito: a arte exerce o papel de aliviar ou de agravar seu estado de melancolia?

\subsection{Justificativa}

O diálogo entre psicologia e história da arte apresenta-se de maneira intensa desde o fim do século XIX, a partir de quando surgem historiadores da arte - como Warburg, Panofsky e Gombrich - cuja compreensão de seu objeto de estudo passa a ser influenciada por sua formação em psicologia (FRAYZE-PEREIRA, 2010).

No caso da literatura dedicada à compreensão da vida e obra de Van Gogh, esse diálogo é ainda mais arraigado, tendo sido o pintor alvo de "uma crítica eivada de psicologismo" (FRAYZE-PEREIRA, 2010). Esse tipo de abordagem pode ser justificada pela maneira como a biografia do artista revela a importância de suas emoções em seu processo de produção artística.

Para Vincent, sua arte era um registro mais verdadeiro, mais revelador ("tão profundo - tão infinitamente profundo") de sua vida, até mais do que a enxurrada de cartas que sempre vinham de acompanhamento. Ele acreditava que toda onda de "serenidade e felicidade", todo estremecimento de dor e desespero ingressavam na pintura; todo sofrimento se infundia em imagens que geravam sofrimento; todo retrato se fazia em autorretrato. E dizia: "Quero pintar o que sinto e sentir o que pinto". (NAIFEH; SMITH, 2012, p. 27)

Além disso, sua história de vida desperta atenção especialmente por causa da instabilidade de sua saúde mental. O fato de que situações trágicas de sua vida - como 
o episódio da orelha cortada ou da mão queimada ${ }^{4}$ - são citadas com frequência mesmo pelo público leigo demonstra o quanto esses acontecimentos, carregados de folclore e simbolismo, atiçam a curiosidade dos que têm contato com sua obra. Todos querem saber mais sobre o gênio maluco, aquele que só vendeu um quadro enquanto vivia e que tirou sua própria vida sem saber se sua arte seria, um dia, compreendida.

Apesar dos numerosos estudos sobre a obra e a personalidade de Van Gogh, muitas questões a respeito do artista permanecem sem resposta. A questão de como suas intensas emoções, em especial a melancolia, deixam-se transparecer em suas telas é um desses enigmas.

A pertinência deste trabalho reside no fato de que decifrar esse mecanismo em Van Gogh seria dar um passo adiante na direção de compreender como se dá a relação entre a criação artística e a melancolia também em outros artistas.

\subsection{Metodologia e quadro teórico de referência}

Para atingir o objetivo geral deste trabalho, que é avaliar se o estado de melancolia de Van Gogh exerceu algum tipo de impacto em sua produção artística, os procedimentos metodológicos adotados consistem na leitura e análise das 139 cartas escritas pelo artista no período que esta pesquisa tem como foco: entre 20 de fevereiro de 1888, quando o pintor chega a Arles, até 23 de dezembro de 1888, quando corta sua própria orelha após um "ataque", termo que ele mesmo usou para descrever o acontecimento.

Ao buscar a publicação mais recente das cartas completas de Van Gogh, descobri com grata surpresa que todas as 819 cartas escritas pelo artista ao longo da vida que foram preservadas por seus correspondentes, podem ser acessadas de forma

\footnotetext{
${ }^{4}$ Em 1880, enquanto van Gogh passava a Páscoa com os pais na cidade de Etten, a família recebeu a visita da prima de Vincent, Cornelia Vos (que era chamada de Kee), junto de seu filho Jan. Van Gogh apaixonou-se pela viúva e declarou-se. Mesmo depois de ser veementemente rejeitado, resolveu tentar convencê-la de suas intenções e foi até Amsterdã, na casa do tio Johannes Stricker, ver a amada. Ao ser informado de que ela não estava, e desconfiando que a alegação era apenas uma desculpa de seu tio, resolveu estender a mão direita sobre o funil de uma lâmpada a óleo e declarar que queria vê-la nem se fosse somente pelo tempo em que aguentasse manter as mãos sobre a chama. Num anticlímax, o tio Stricker simplesmente apagou a lâmpada e manteve-se firme na intenção de não deixá-lo ver a filha Kee. A mão ficou apenas superficialmente ferida.
} 
gratuita pelo site www.vangoghletters.org. Essa publicação, que também ganhou uma edição em livro, com seis volumes, ocorreu em 2009, após 15 anos de trabalho de pesquisadores do Van Gogh Museum e do Huygens Institute of the Royal Netherlands Academy of Arts and Sciences. A equipe, coordenada por Leo Jansen, Hans Luijten e Nienke Bakker, revisou os manuscritos e fez nova tradução das línguas originais para o inglês, além de acrescentar notas explanatórias. O trabalho inclui a identificação dos indivíduos citados pelas cartas, bem como as obras de arte mencionadas e a origem de alusões e citações que aparecem nas correspondências.

Na página da internet, o leitor pode acessar os textos originais das cartas, os fac-símiles, as notas explanatórias, a tradução dos textos para o inglês e as imagens de todas as obras mencionadas ao longo do diálogo entre Van Gogh e seus correspondentes.

Cabe observar que, das 139 cartas analisadas, 133 foram lidas na língua original (131 em francês e 2 em inglês). Em 6 delas, escritas originalmente em holandês, coube recorrer à tradução para o inglês. As citações a trechos das cartas feitas neste trabalho, portanto, foram traduzidas por mim a partir da língua original ou a partir do inglês, no caso das que estavam originalmente em holandês. Os números referentes às cartas aqui adotados são aqueles definidos por Jansen, Luijten e Bakker nessa última revisão da correspondência.

Se todo esse material chegou até nós, muito se deve ao empenho da viúva de Theo, Johanna van Gogh-Bonger. Pouco menos de seis meses após a morte de Van Gogh, em 29 de julho de 1890, seu irmão Theo também morre, em 25 de janeiro de 1891. Além de ser seu principal correspondente, Theo era também quem sustentava financeiramente o irmão e o detentor de muitas de suas obras.

Por ocasião de sua morte, quem fica responsável pelo patrimônio artístico e literário dos irmãos Van Gogh é Johanna, então com 29 anos. Na época, Vincent não tinha muita relevância no meio artístico e não gozava de grande reconhecimento nem mesmo por parte de seus colegas artistas. Ainda assim, Johanna acreditou na importância de reunir e preservar cerca de 550 pinturas, várias centenas de desenhos e uma enorme e desordenada pilha de cartas. 
Coube a Jo, a viúva de Theo, realizar o milagre de transformar o nome insignificante de um suicida obscuro, que só expusera umas poucas telas em algumas mostras de vanguarda, e que de fato só vendera um quadro em toda a sua vida, no do artista mais famoso de seu tempo. (SWEETMAN, 1993, p. 283)

No prefácio da "Biografia de Vincent van Gogh por sua cunhada" (VAN GOGHBONGER, 2008), o filho de Theo e Johanna, também chamado Vincent Willem van Gogh - como o tio famoso - relata que sua mãe se esforçou ao longo de muitos anos para colocar as cartas de Vincent em ordem cronológica, já que muitas não tinham data.

A primeira edição das cartas foi lançada em três volumes em Amsterdã em 1914. Um dos muitos biógrafos de Van Gogh, o britânico David Sweetman, conta que Johanna chegou a adiar a publicação, já que ela considerava que os detalhes pessoais da vida do artista só deveriam ser revelados quando sua obra fosse mais bem assimilada pelo público. "As cartas foram publicadas nas várias línguas em que Vincent as escrevera. A introdução - um relato de Jo sobre a vida de Vincent, sobretudo a partir de lembranças do que Theo lhe contara - foi a base de todas as biografias subsequentes de Vincent" (SWEETMAN, 1993, p. 285).

Em 1915, ela se mudou para Nova York, onde começou a traduzir as cartas para o inglês. Quando morreu, no dia 2 de setembro de 1925, tinha chegado até a carta número 526, de acordo com seu filho Vincent Willem.

As cartas são escritas com tal frequência que correspondem a registros quase diários do estado de espírito do pintor. Nelas, Van Gogh discorre sobre o trabalho, os anseios e as angústias, demonstrando assim seu modo de ver o mundo. Para Sweetman, a análise das cartas é um procedimento primordial para compreender a essência do artista:

É preciso retornar às suas próprias palavras para descobrir a verdade. Ele se deu a considerável trabalho para explicar seu pensamento em sua extensa correspondência, e o tempo dedicado às pinturas, seguido da leitura de suas cartas, principalmente a seu irmão Theo, é um dos prazeres mais iluminantes que o estudo da arte tem a oferecer. (SWEETMAN, 1993, p. 10) 
No prefácio do livro "Vincent van Gogh: Un Studio psicológico", do psiquiatra Humberto Nagera, a psicanalista Anna Freud também destaca a maneira como as cartas revelam os sofrimentos de Van Gogh:

As cartas de Vincent van Gogh em que se baseiam este livro têm emocionado o leitor pela sinceridade dos sentimentos expressados nelas, por sua força expressiva, pela profundidade dos sofrimentos humanos que refletem e pelos lampejos de intuição que manifestam uma e outra vez. Em suas cartas, van Gogh dá um testemunho necessariamente subjetivo dos acontecimentos que marcaram sua existência. (FREUD, 1980, p. 7, tradução nossa)

Conhecendo o caráter oscilante do estado de espírito do pintor ao longo dessa fase, busca-se determinar, por meio da análise desses documentos, os períodos em que suas palavras revelam um estado de espírito melancólico e sombrio, assim como os momentos em que seu discurso aponta para um estado eufórico e entusiasmado.

O discurso do sujeito, a escolha que ele faz das palavras, além do uso da entonação e do ritmo podem denunciar, ainda que involuntariamente, a presença da melancolia e da tristeza. Julia Kristeva descreve o discurso do deprimido como uma ladainha repetitiva.

Lembrem-se das palavras do deprimido: repetitivas e monótonas. Diante da impossibilidade de se encadear, a frase se interrompe, se desgasta, para. Mesmo os sintagmas não chegam a se formular. Um ritmo repetitivo, uma melodia monótona vem dominar as sequências lógicas rompidas e as transformar em ladainhas recorrentes, obsessivas. (KRISTEVA, 1987, tradução nossa)

A análise das cartas de Van Gogh resulta na identificação de algumas das características citadas por Kristeva. Frases interrompidas e ideias descritas apenas pela metade aparecem em algumas das cartas escritas durante o período.

Outro fenômeno destacado por Kristeva a respeito do discurso do deprimido é a observação de que aquele que é acometido pela depressão, por sofrer um "luto impossível do objeto maternal", é como um estrangeiro na língua materna, já que não consegue integrar-se plenamente à "cadeia significante universal - a linguagem".

A fala do depressivo é para ele como uma pele estrangeira: o melancólico é um estrangeiro em sua língua materna. Ele perdeu o sentido - o valor - de sua língua materna, à falta de perder sua mãe. A 
língua morta que ele fala e que anuncia seu suicídio esconde uma Coisa enterrada viva. (KRISTEVA, 1987)

A autora descreve ainda o discurso do depressivo como "uma máscara - bela fachada entalhada em uma "língua estrangeira'". Esse fenômeno - de ser estranho à própria língua materna - pode ser identificado literalmente na correspondência de Van Gogh. A partir do momento em que decide ser artista, ele começa a se corresponder com o irmão Theo em francês, no lugar do holandês materno.

O uso do francês para dirigir-se a seu irmão, com quem seria natural conversar em holandês, aparece pela primeira vez em carta de 15 de outubro de 1880, quando o artista chega a Bruxelas com o objetivo de aprender a desenhar. A escolha parece "frisar o fato de que uma nova vida estava começando" (SWEETMAN, 1993). Um comentário sobre o fato de ele se sentir mais à vontade ao se expressar em francês também aparece em uma carta à irmã Willemien, de 26 de agosto de 1888, quando ele passa a dirigir-se também a ela na língua francesa: "Minha querida irmã, se você me deixar escrever-lhe em francês, isso realmente me simplificará a carta" (Carta 670).

Acima de tudo, e além da observação das características do discurso do deprimido elaboradas por Kristeva, a determinação do estado de espírito de Van Gogh ao longo do período selecionado torna-se possível graças ao fato de que ele próprio se dispunha a descrever sua atitude mental ao longo das cartas. Apesar de ter mencionado certa vez, em carta à irmã Willemien, que detestava escrever sobre si mesmo e que não sabia por que o fazia (carta 626), o fato é que são frequentes os trechos em que busca transmitir ao destinatário exatamente o que está sentindo no momento em que se senta à mesa com papel e pena na mão.

"No presente, eu sofro bastante certos dias, mas isso não me preocupa de maneira alguma, já que não é nada além da reação a este inverno fora do comum", escreve Van Gogh a Theo em 9 de abril de 1888 (Carta 594), evidenciando seu sofrimento nos primeiros meses da estadia em Arles. Em outra ocasião, em 8 de setembro de 1888 , fala ao irmão sobre a chegada de dias melhores e mais alegres: “(...) após algumas semanas de preocupações, tenho tido uma semana bem melhor. $E$ assim como as preocupações não vêm sozinhas, as alegrias também não" (Carta 676).

Depois de uma leitura sistemática dos documentos em busca de trechos como os citados, que evidenciam o estado de espírito do artista naquele momento, a 
pesquisa procedeu à análise das pinturas produzidas nesses períodos distintos e a escolha de algumas obras para serem analisadas mais profundamente, de modo que se torne possível comparar os trabalhos produzidos em momentos de melancolia com aqueles produzidos em momentos de euforia.

Para tornar a comparação mais consistente, essa escolha recaiu sobre obras com um tema comum. Dessa forma, torna-se possível observar como o mesmo tema foi representado pelo artista enquanto experimentava sentimentos distintos e identificar quais são as diferenças entre essas representações.

Neste ponto, tendo em vista que este trabalho parte de uma aproximação de elementos da psicologia - representados aqui pela identificação de características psicológicas do artista presentes no texto de sua correspondência e pela busca por essas mesmas características em sua pintura - com a estética e a história da arte, é pertinente retomar algumas considerações feitas por Frayze-Pereira em "Arte, Dor: Inquietudes entre Estética e Psicanálise". O autor cita o escritor francês René Huyghe ao afirmar que, para a psicologia da arte, o principal objeto de análise é a própria obra de arte, cuja leitura "permite decifrar não só o que um homem dispôs nela intencionalmente, mas também o que nela colocou inconscientemente, de si próprio e do grupo humano a que pertence" (HUYGHE, 1986 apud FRAYZE-PEREIRA, 2010, p. 65).

Apesar de essa leitura ser possível, como mostra Huyghe, Frayze-Pereira alerta para o fato de que simplesmente usar a obra de arte como o objeto por meio do qual o psicanalista pretende diagnosticar e decifrar o artista, da mesma forma que interpreta seu paciente por meio da fala, é uma visão muito simplista da relação entre arte e psicanálise. Dessa forma, a obra acaba "reduzida à função sintomática de mascarar significados que o analista, como sujeito do saber psicanalítico, crê desvelar por um poder interpretativo oriundo desse saber" (FRAYZE-PEREIRA, 2010, p. 70).

Portanto, a definição dos critérios para a análise das obras selecionadas de Van Gogh deve levar em conta essas observações, para que a interpretação não resulte demasiado simplista nem reduza as pinturas a meros sintomas.

Por fim, para atingir os objetivos de identificar se o estado de melancolia em Van Gogh impulsiona ou inibe sua produtividade artística e identificar se, por outro lado, a arte tem o efeito de aliviar ou agravar seu estado de melancolia, esta pesquisa recorre novamente às cartas. O intuito é verificar qual é a percepção do próprio pintor 
em relação a essas questões. Outras fontes a quem este trabalho também deve recorrer para tratar desse tema são os biógrafos de Van Gogh com o propósito de reunir as visões dos diferentes autores sobre a relação entre melancolia e arte na figura de Van Gogh.

Desde a morte de Van Gogh, centenas, se não milhares de estudos já foram publicados a respeito de sua vida e obra. Frayze-Pereira cita que, de acordo com um registro de 1942, até essa data já se podiam contar 777 pesquisas divulgadas sobre o tema (FRAYZE-PEREIRA, 2010).

Um levantamento inicial para o desenvolvimento desta pesquisa chegou a diversas biografias do pintor holandês. Entre elas, destacam-se as de Meyer Schapiro (1950), Dino Formaggio (1952), Henri Perruchot (1959), Viviane Forrester (1983), Jorge Coli (1985), Julius Meier-Graefe (1987), entre outras.

A escolha das biografias que norteariam este trabalho recaiu sobre quatro autores principais: David Sweetman (1993), Pascal Bonafoux (2011), Steven Naifeh e Gregory White Smith (2012).

Estes dois últimos são os responsáveis pela mais recente publicação sobre o tema: "Van Gogh: A vida" (NAIFEH; SMITH, 2012). O trabalho é resultado de 10 anos de meticulosa pesquisa e chamou a atenção da crítica ao sugerir que Van Gogh não se matou, mas teria sido atingido por um tiro acidental disparado por um jovem chamado René Secrétan. O estudo extremamente detalhado contou com o apoio de pesquisadores do Van Gogh Museum, cujo curador, Leo Jansen, definiu a obra como "a biografia definitiva para as próximas décadas". As características da obra fazem com que ela seja a fonte de referência mais atualizada e detalhada sobre a vida do pintor.

Se as mais de mil páginas de "Van Gogh: A vida" primam pelo detalhamento e levam em conta uma quantidade imensa de fontes documentais (somente as notas da obra resultaram em cerca de 5 mil páginas datilografadas, segundo os autores, motivo pelo qual elas não foram publicadas na forma impressa, mas no site www.vangoghbiography.com), a obra de David Sweetman "Van Gogh: Uma biografia” (SWEETMAN, 1993), tem como qualidade a abordagem cuidadosa, ainda que mais 
concisa, sobre as características psicológicas de Van Gogh. Tendo sido a primeira biografia a que tive acesso, desempenhou um papel importante para a elaboração do projeto de pesquisa para esta dissertação (o livro de Naifeh e Smith seria publicado no Brasil apenas em novembro de 2012).

O trabalho de Pascal Bonafoux também foi importante para esta pesquisa, principalmente por trazer a reprodução de textos de críticos e escritores a respeito da obra de van Gogh, como Georges Bataille, Antonin Artaud e Georges-Albert Aurier, responsável pela primeira crítica relevante a respeito de Van Gogh, publicada em janeiro de 1890 no "Mercure de France" (BONAFOUX, 2011).

Outra peça importante para a montagem do quebra-cabeça que constitui a personalidade e as características psicológicas de van Gogh foi o livro "Vincent van Gogh: Un studio psicológico", do psiquiatra Humberto Nagera (NAGERA, 1980). Uma de suas contribuições foi trazer novas hipóteses para o que pode ter contribuído para o desencadeamento das crises que tiveram início em Arles.

A respeito da busca póstuma por um diagnóstico mental preciso para Van Gogh, o médico afirma que não seria possível chegar a uma conclusão definitiva, opinião que compartilho com o autor, motivo pelo qual este trabalho não adota nenhuma das hipóteses como a única correta. 
2 Van Gogh e a Melancolia

Antes de começar a discorrer sobre a melancolia em Van Gogh, é importante trazer à luz duas questões principais. Primeiro, é preciso promover uma revisão a respeito da evolução histórica do conceito de melancolia, levando em conta que muitas definições que já foram associadas ao termo desde seu primeiro registro, no século V a.C. Em seguida, faz-se necessário compreender que tipo de relação o próprio Van Gogh estabelecia com esse termo, tomando por base as referências que ele faz à melancolia ao longo de sua correspondência. Desta forma, é possível determinar qual é a definição de melancolia a ser tomada como referência por este trabalho.

Com o objetivo de compreender melhor a trajetória de vida do personagem principal desta pesquisa, este capítulo também traz um resumo sobre a vida de Van Gogh até sua chegada à cidade de Arles, quando começa a análise de sua obra e de suas cartas.

\subsection{Evolução histórica do conceito de melancolia}

Antes de começar a abordar a questão da melancolia em Van Gogh, é importante discorrer sobre a evolução histórica do conceito de melancolia e determinar qual definição - entre as muitas que já foram associadas ao termo desde seu primeiro registro no século V a.C - será tomada como referência neste trabalho. Ao longo dos séculos, o termo melancolia tem incorporado significados e conotações distintas, como observam Klibansky, Panofsky e Saxl (1964): "Embora novos significados tenham emergido, os velhos significados não deram lugar a eles; em suma, foi um caso não de decadência e metamorfose, mas de sobrevivência paralela." 0 conceito de melancolia carrega, portanto, uma pesada bagagem histórica que deve ser levada em consideração por trabalhos atuais sobre o tema.

\section{Doutrina dos quatro humores}


Para falar da origem do conceito de melancolia, é preciso voltar à antiga doutrina dos quatro humores, que determinava a existência de quatro humores corporais: a bile negra, a fleuma, a bile amarela e o sangue. Acreditava-se que a proporção desses humores no organismo determinava a saúde, o caráter e o temperamento dos indivíduos.

O sistema foi adotado durante muito tempo tanto pela medicina quanto pela psicologia, havendo registros de seu uso clínico até o século XIX, quando a nova teoria sobre doenças mentais desenvolvida pelo médico francês Philippe Pinel aboliu o uso do vocabulário da teoria dos humores (LAMBOTTE, 2000). Até o século XVIII, tratamentos baseados no humoralismo como sangrias, expurgos e vomitórios ainda eram correntes na prática clínica. Eles seguiam o princípio de que a eliminação do excesso de determinados humores poderia levar ao equilíbrio e à saúde.

O primeiro registro de que se tem conhecimento de uma descrição sistemática dos quatro humores aparece na obra "Da natureza do homem", texto atribuído a Hipócrates, ou a seu genro Pólibo (KLIBANSKY; PANOFSKY; SAXL, 1964).

Mas antes mesmo dessa sistematização, três antigos princípios gregos já prenunciavam o surgimento da doutrina dos humores: a busca por elementos simples que dessem origem a toda a complexidade do universo; a busca por uma expressão numérica capaz de abarcar toda a estrutura da existência carnal e espiritual e a teoria da harmonia, simetria e proporcionalidade, que os gregos pensavam ser essencial tanto para os valores estéticos quanto para os valores morais, de higiene e de saúde.

Em última instância, a doutrina dos quatro humores resultou da evolução e da agregação de teorias anteriores propostas por pensadores da Escola Pitagórica, de acordo com Klibansky, Panofsky e Saxl (1964).

Primeiro, Alcmeão de Crotona, médico pitagórico que viveu em 500 a.C, propôs que a saúde era resultado do equilíbrio de qualidades como úmido e seco, amargo e doce, frio e quente, entre outras.

Já Filolau deu um passo a mais rumo à doutrina humoral elegendo o número quatro com o "princípio da saúde". Posteriormente, Empédocles criou a teoria dos quatro elementos cósmicos, segundo a qual terra, fogo, água e ar seriam os elementos constituintes de toda a matéria. A proporção de cada elemento presente no indivíduo determinaria suas características. Um homem no qual os elementos estivessem em 
equilíbrio, por exemplo, teria melhor compreensão da vida. Já o homem em que um dos elementos sobressaísse em relação aos outros teria uma capacidade intelectual limitada.

Empédocles começou, dessa forma, a relacionar a parte física e mental do ser humano, dando origem a uma teoria psicossomática. Mas sua teoria ainda não especificava quais eram as matérias físicas, dentro do homem, que pudessem comprovar a teoria.

Para se chegar à doutrina dos quatro humores ainda faltava relacionar os quatro elementos cósmicos com elementos presentes no corpo humano. Buscavam-se substâncias específicas da constituição física do homem que correspondessem aos elementos primários do universo.

Filistião chegou a associar os quatro elementos cósmicos com as características calor, frio, úmido e seco, conciliando dessa forma a teoria de Empédocles com a de Alcmeão de Crotona, que dizia respeito à saúde como resultado do equilíbrio entre as qualidades.

Mas foi Hipócrates quem finalmente determinou a existência de quatro humores responsáveis pela constituição física e mental do homem. Antes dele, já se falava na existência dos humores como causadores ou sintomas de doenças, já que eles se tornavam visíveis em situações como o vômito. Mas as teorias correntes apontavam para a existência de apenas dois humores - a fleuma e a bile - ou então de inúmeros humores.

Hipócrates transformou-os em quatro ao incluir o sangue e dividir a bile em duas: a bile amarela e a bile negra. Segundo a teoria hipocrática, os quatro humores poderiam levar tanto à saúde quanto à doença: enquanto a combinação correta resultava em saúde, a predominância ou a falta de um deles produzia a doença.

Além disso, Hipócrates determinou as combinações de características associadas a cada um dos humores: o sangue seria quente e úmido, a bile amarela seria quente e seca, a bile negra seria fria e seca e a fleuma, fria e úmida. Ele propôs também que cada estação do ano estaria associada à ascensão de um humor: a primavera foi associada ao sangue, o verão à bile amarela, o outono à bile negra e o inverno à fleuma. 
O termo melancolia, em grego, designa justamente a "condição de ter bile negra". A palavra grega $\mu \varepsilon \lambda \alpha \gamma \chi \chi \lambda i \alpha$ (ou melagkholía) é composta pela junção de $\mu \varepsilon \dot{\lambda} \alpha \varsigma$

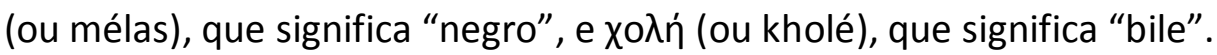

\section{Da saúde ao temperamento}

Se, a princípio, a doutrina dos quatro humores dizia respeito exclusivamente à saúde do indivíduo, ela passou gradualmente a designar também o temperamento das pessoas. Como a situação de manter um equilíbrio absoluto entre todos os humores, 0 que determinaria que o indivíduo nunca adoecesse, era virtualmente impossível, a predominância de um ou de outro humor passou a ser vista como um tipo de disposição.

Dessa forma, as palavras "colérico", "fleumático", "melancólico" ou "sanguíneo" tinham duas possíveis aplicações: poderiam tanto denotar estados patológicos quanto aptidões constitucionais.

No caso da melancolia, a doença provocada pelo excesso de bile negra era principalmente caracterizada por sintomas mentais, variando desde medo, misantropia e depressão até loucura em suas formas mais assustadoras. A ambiguidade desses sintomas psicológicos levou ao reconhecimento de situações em que um indivíduo, apesar de apresentar hábitos melancólicos, não era considerado necessariamente doente. Na melancolia, essa distinção entre a doença e a mera predisposição ocorreu antes do que nos outros humores.

Ainda segundo Klibansky, Panofsky e Saxl (1964), essa peculiaridade abriu caminho para a transformação da teoria dos quatro humores em uma teoria do temperamento e dos tipos mentais.

\section{Melancolia como dádiva}

Aristóteles leva em frente o processo de desassociar a melancolia da esfera patológica. Para ele, o doente da bile negra não é necessariamente melancólico, nem o melancólico é necessariamente doente da bile negra (ARISTÓTELES; PIGEAUD, 1998). Na visão de Aristóteles, além de existir uma "saúde do melancólico", a melancolia estaria intimamente relacionada ao que se pode chamar de "genialidade". O filósofo abre seu texto "Problema XXX, I" com o célebre questionamento: 
Por que razão todos os que foram homens de exceção, no que concerne à filosofia, à ciência do Estado, à poesia ou às artes, são manifestamente melancólicos, e alguns a ponto de serem tomados por males dos quais a bile negra é a origem, como contam, entre os relatos relativos aos heróis, os que são consagrados a Hércules? (ARISTÓTELES; PIGEAUD, 1998)

No século IV a.C, segundo observam Klibansky, Panofsky e Saxl (1964), a noção de melancolia passou a ser associada às figuras míticas heroicas como Héracles, Ájax e Belerofonte. O encanto exercido por essas figuras era forte o suficiente para dar à noção de melancolia uma "aura de sinistra sublimidade". A melancolia tornou-se a "doença dos heróis".

Platão já havia interpretado a loucura como uma "dádiva divina". Aristóteles ao associar a loucura à melancolia - concluiu que a melancolia também conferia o caráter excepcional a todos os bem dotados nas áreas de filosofia, poesia e arte.

“Dessa forma, a noção de melancolia adquiriu por sua vez um conteúdo novo e positivo e, graças a ele, foi possível de uma só vez reconhecer e explicar o fenômeno do "homem de gênio'” (KLIBANSKY; PANOFSKY; SAXL, 1964). De acordo com essa visão, a loucura divina passou a ser vista como uma sensibilidade de alma e a grandeza espiritual de um homem era medida por sua capacidade para a experiência e, sobretudo, para o sofrimento.

Em “Problema XXX, I", Aristóteles estabelece uma curiosa comparação entre os efeitos do vinho e os efeitos da bile negra no organismo. Os dois são "modeladores de caráter" e a bile negra, assim como o vinho, teria a capacidade de produzir todos os estados de personalidade em um mesmo indivíduo.

"Isto quer dizer que o melancólico tem em si, como possíveis, todos os caracteres de todos os homens. O que esclarece prodigiosamente, como veremos, a ideia mesma da criatividade melancólica." (ARISTÓTELES; PIGEAUD, 1998)

Ao interpretar o texto de Aristóteles, Pigeaud descreve o melancólico como aquele que, pelo efeito da bile que o corrói, não tolera a sobriedade calma da vida. "Pela mesma razão, é um ser de violência e de contraste, vítima da mudança incessante; ele é incompreensível". Para ela, o coração do problema proposto por Aristóteles é como a inconstância do indivíduo melancólico pode explicar sua grandeza 
e sua criatividade. O texto, que não responde à questão de forma fechada, tem o objetivo de levantar o problema e apresentar argumentos para reflexão.

De fato, a relação entre o temperamento melancólico e a criatividade, mais especificamente a inclinação para a arte, é uma questão que intriga até hoje e para a qual não existe resposta definitiva. Essa discussão faz-se especialmente importante na medida em que um dos objetivos específicos desta dissertação é entender de que forma o temperamento de Van Gogh, descrito por ele próprio como melancólico, pode ter influenciado sua produção artística. A visão de outros pensadores sobre o tema será abordada ao longo deste trabalho.

\section{A melancolia depois de Aristóteles}

Na Antiguidade, depois de Aristóteles, manteve-se a ideia de que havia alguma ligação especial entre a melancolia e a vida intelectual. Porém, a tese apresentada em "Problema XXX, I", de que todo homem de gênio seria melancólico, era vista com ressalvas ou ironia.

A partir do século III a.C, os estoicos passaram a ver a melancolia não como requisito para dons excepcionais, mas como doença severa que os excepcionalmente dotados têm mais risco de desenvolver. Ou seja, enquanto para Aristóteles a melancolia predispunha à genialidade, para os estoicos, a genialidade predispunha à melancolia.

Já Rufo de Éfeso, médico que viveu no século I d.C, defendia que a atividade mental era a causa direta da doença melancólica. Segundo Klibansky, Panofsky e Saxl (1964), essa teoria evidencia uma visão especificamente médica sobre a questão, em

oposição àquelas dos filósofos naturais ou morais. Dessa forma, "o destino trágico de um homem de gênio tornou-se meramente a 'má disposição' de um estudioso sobrecarregado".

Nessa época, os sintomas da melancolia já tinham sido estabelecidos: os melancólicos eram pessoas "atormentadas por toda sorte de desejos, deprimidas; covardes e misantropas; geralmente tristes sem causa, mas às vezes imoderadamente alegres; dadas a várias excentricidades, fobias e obsessões" (KLIBANSKY; PANOFSKY; SAXL, 1964). 


\section{Idade Média e Renascimento}

As ideias de Aristóteles sobre a relação entre melancolia e genialidade eram ainda menos aceitas na Idade Média, quando, devido à crescente influência da Igreja, o valor de um indivíduo não era medido de acordo com seu talento intelectual, mas com suas virtudes pelas quais Deus Ihe dava forças para perseverar. $\mathrm{O}$ cristianismo fez da tristeza um pecado e, nessa época, "ter um coração morno" significava ter perdido Deus (KRISTEVA, 1987).

Ao longo de toda a Idade Média, a ideia dos melancólicos com capacidade intelectual excepcional foi deixada de lado para ser retomada somente no Renascimento.

No geral, a Idade Média teve pouco interesse na interpretação do 'Problema XXX, I', enquanto os escritores do Renascimento, percebendo muito cedo o verdadeiro significado da distinção entre melancolia natural e patológica, passaram a aplicá-la independentemente de sua divergência em relação à já vulgarizada doutrina das compleições (KLIBANSKY; PANOFSKY; SAXL, 1964)

\section{Outras interpretações sobre a melancolia}

É importante observar que a melancolia aparece, em diversos autores, associada à loucura. Em "História da Loucura na Idade Clássica", Michel Foucault descreve algumas dessas classificações de loucura das quais a melancolia faz parte. Segundo Paracelso, médico e alquimista suíço que viveu no século XVI, por exemplo, existiriam quatro tipos de loucura: lunatici (influenciada pela lua), insani (loucura hereditária), vesani (loucura pelo mau uso da bebida ou comida) e melancholici (vício de natureza interna).

Em 1621, o acadêmico britânico Robert Burton publicou o livro "The Anatomy of Melancholy". Trata-se de uma espécie de enciclopédia que se propõe, ao longo de suas mais de mil páginas, a compilar de forma científica todo o conhecimento acumulado pela humanidade a respeito da melancolia, desde a Grécia antiga até as teorias da medicina do século XVII.

O próprio autor se dizia acometido pelos males da bile negra e afirmava que um dos motivos que o levou a se debruçar com tanto afinco sobre o tema foi esquecer ou 
amenizar seu próprio temperamento. Ironicamente, a obra que detalha com tanta propriedade as características da melancolia foi interpretada, na época, como uma obra de entretenimento. Apesar da seriedade do trabalho de pesquisa e da riqueza de fontes consultadas por Burton, muitos o liam como um livro de humor.

Analistas julgam que o efeito cômico se dá justamente pelo detalhamento com que o temperamento melancólico é descrito neste que já foi considerado um manual médico, um livro de autoajuda ou uma compilação de citações. Burton classifica a melancolia de forma tão específica a ponto de criar um verbete sobre a melancolia provocada pelo consumo de água parada.

Observa-se que, mesmo nessa época, a visão medieval da melancolia enquanto degeneração moral e castigo divino ainda estava presente:

(...) enquanto formos regrados pela razão, corrigirmos nosso apetite excessivo e permanecermos em conformidade com a palavra de Deus, ficaremos como todos os santos: mas se dermos rédeas a luxúria, ódio, ambição, orgulho e seguirmos nossos próprios caminhos, nós degeneramos em animais, nos transformamos, derrubamos nossas constituições, provocamos o ódio de Deus, e se amontoa por cima de nós essa melancolia, e todos os tipos de doenças incuráveis, como uma punição justa e merecida por nossos pecados. (BURTON, 2001)

Já no século XX, em "Luto e Melancolia", Freud faz uma abordagem psicanalítica da chamada psicose maníaco-depressiva (FREUD, 2013). E por que, depois de a medicina já ter superado o termo "melancolia" - com a teoria Philippe Pinel tendo abolindo o uso desse vocabulário no âmbito médico, relegando-o ao domínio dos filósofos e poetas - Freud escolhe justamente esse significante? Segundo Maria Rita Kehl, no texto de abertura para a edição brasileira da obra, é provável que ele tenha escolhido a antiga e romântica designação de melancolia para "estabelecer uma distinção entre a abordagem psicanalítica da doença e aquela já consagrada pela medicina do século XIX".

Nessa obra, Freud estabelece uma comparação entre a melancolia e o luto. Para ele, os dois processos envolvem uma perda. A diferença é que o melancólico não sabe a natureza do objeto perdido nem a origem da perda, ao contrário da pessoa em luto. 
Ele descreve um processo em que, diante do abalo de uma relação com a pessoa amada, em vez da retirada da libido para outro objeto, ela se volta para o próprio ego, onde ocorre uma identificação com o objeto amado. Dessa forma, segundo Freud, a "sombra do objeto" recai sobre o ego e o conflito que deveria ser entre o sujeito e o objeto amado passa a ocorrer entre duas instâncias internas do próprio ego. "Assim, a perda do objeto se transformou em perda do ego" (FREUD, 2013). Nessas ocasiões, não é raro que o paciente tente vingar-se do objeto por meio de autopunição.

"O doente nos descreve o seu ego como indigno, incapaz e moralmente desprezível; ele se recrimina, se insulta e espera ser rejeitado e castigado. Humilha-se perante os demais e tem pena dos seus por estarem eles ligados a uma pessoa tão indigna." (FREUD, 2013). Toda essa crítica dirigida a si mesmo, portanto, tem como alvo original o objeto amado.

Diferentemente da tradição inaugurada por Aristóteles, Freud não estabelece qualquer relação entre melancolia e criação artística ou genialidade. Pelo contrário: Freud descreve que a melancolia inibe toda a atividade ao provocar um desânimo profundamente doloroso, a suspensão do interesse pelo mundo externo, a perda da capacidade de amar e o rebaixamento do sentimento de autoestima. Para Freud, o melancólico é incapaz para o trabalho.

Freud lembra que a definição conceitual da melancolia é oscilante e ele próprio renuncia à reivindicação da validade universal de suas conclusões. Sobre ela, ele diz que “(...) mesmo na psiquiatria descritiva, apresenta-se sob várias formas clínicas, cuja síntese em uma unidade não parece assegurada, e dentre estas algumas sugerem afecções mais somáticas que psicógenas".

Em uma abordagem que guarda semelhanças com a de Freud, Julia Kristeva define a melancolia como uma ferida aberta ao descobrir que a dor não é mais do que o ódio nutrido por aquele que se ama e que o traiu ou o abandonou. Como Freud, ela também associa a melancolia à perda de um objeto amado. Como quem já experimentou a sensação de estar sob o "sol negro", é dessa forma que ela descreve o fenômeno: 
“Estou tentando lhe falar de um abismo de tristeza, dor incomunicável que nos absorve às vezes, e frequentemente por muito tempo, até nos fazer perder o gosto de qualquer palavra, de qualquer ato, o gosto mesmo da vida." (KRISTEVA, 1987).

Diferentemente de Freud, Kristeva relaciona a melancolia à criação estética. Para ela, a arte tem um papel de sublimação. Nesses casos, o belo atua como substituto do objeto perdido.

“(...) As artes parecem indicar alguns métodos que evitam a conveniência e que, sem simplesmente reverter o luto em mania, garantem ao artista e ao conhecedor uma adesão sublimatória sobre a coisa perdida." (KRISTEVA, 1987).

\section{Melancolia e mania}

Freud cita como a "peculiaridade mais notável da melancolia" a tendência a se transformar no estado sintomaticamente oposto: a mania. Segundo ele, ambas as afecções lutam com o mesmo complexo - o ego sucumbe a ele na melancolia e o supera na mania.

(...) na mania, o ego precisa ter superado a perda do objeto (ou o luto pela perda, ou talvez o próprio objeto) e desse modo todo o montante de contrainvestimento que o doloroso sofrimento da melancolia atraíra do ego para si e ligara fica agora disponível. Na medida em que, como um faminto, o maníaco sai em busca de novos investimentos de objeto, ele nos demonstra de um modo inequívoco sua libertação do objeto que o fez sofrer. (FREUD, 2013)

Kristeva também define a melancolia como uma fase de inibição e assimbolia que se instala no indivíduo cronicamente ou alternadamente com a fase maníaca de exaltação.

Um dos primeiros a propor a alternância entre mania e melancolia, segundo Foucault, foi o médico inglês Thomas Willis, no século XVII. E a proposta não veio da observação de casos, mas da afinidade profunda que ele via entre esses dois estados:

Da mania à melancolia, é evidente a afinidade: não é a afinidade de sintomas que se encadeiam na experiência: é a afinidade, bem mais forte e muito mais evidente nas paisagens da imaginação, que enlaça, num mesmo fogo, a fumaça e a chama. (FOUCAULT, 1978) 


\section{De que melancolia estamos falando?}

Kristeva afirma que os limites entre as definições de melancolia e de depressão são vagos. Ambas estariam relacionadas à perda do objeto e à modificação dos laços significantes. Apesar das semelhanças, segundo ela, a psiquiatria costuma denominar melancolia a doença irreversível, que não responde aos remédios. Já Urania Tourinho Peres afirma que a melancolia pode ser vista como um conceito romântico, enquanto a depressão, um estado de doença (PERES, 2003).

O fato é que, na medicina atual, o termo melancolia não tem espaço. Se observarmos a Classificação Estatística Internacional de Doenças e Problemas Relacionados à Saúde - Décima Revisão (CID-10), documento desenvolvido pela Organização Mundial da Saúde (OMS) que serve como parâmetro mundial para diagnósticos, a melancolia não faz parte das doenças catalogadas. Ela tampouco aparece na versão mais recente do Manual Diagnóstico e Estatístico de Transtornos Mentais (DSM-5), elaborado pela Associação Americana de Psiquiatria. Falar de melancolia hoje, portanto, não é falar de uma doença específica, de uma afeç̧ão passível de ser diagnosticada com critérios objetivos.

Apesar das muitas definições possíveis para o termo, para Pigeaud, a visão ocidental da melancolia é formada basicamente pela confluência de três tradições "que se sedimentaram e misturaram de diversos modos" (ARISTÓTELES; PIGEAUD, 1998).

A primeira é a tradição de Hipócrates, que foi quem primeiro definiu o conceito. No 23 aforismo do livro VI dos "Aforismos de Hipócrates", aparece a tentativa inicial de sistematizar o termo: "Se tristeza (distimia) e medo duram muito, um tal estado é melancólico". A segunda tradição consiste no texto "Problema XXX, I", de Aristóteles, sobre o qual este trabalho já versou.

A terceira fonte são as "Cartas do Pseudo-Hipócrates", em que aparece o personagem Demócrito, que apresenta sintomas de loucura e melancolia. "A longa carta 17 para Damagetes é continuamente citada, através dos séculos, como testemunha sobre o sentido da loucura, e particularmente da melancolia" (ARISTÓTELES; PIGEAUD, 1998).

Quando falo de melancolia neste trabalho, portanto, evoco toda a bagagem histórica do termo, desde seu surgimento no contexto da doutrina dos humores, no 
século $V$ a.C, até as definições mais modernas. Não estou me referindo a um transtorno mental catalogado pela psiquiatria, mas a uma definição quase poética de um temperamento, de um estado de espírito específico frequentemente associado aos artistas. Busco, desta forma, referir-me ao que o próprio Van Gogh tinha em mente quando usava o termo melancolia para definir suas emoções e seu trabalho ao longo de suas cartas.

Em "Estética da melancolia", Lambotte (2000) afirma que a melancolia vem acompanhada de um discurso específico, da capacidade do sujeito de dissertar sobre a legitimidade de sua própria doença. A autora cita que Kirkegaard costumava discorrer em suas obras sobre seu próprio comportamento melancólico:

(...) entretanto, como não se trata aqui de classificar nossos autores sob uma categoria psicológica qualquer, nem de tirar partido de seus escritos em vista de uma interpretação que exceda sua significação literária ou imediata, recorreremos às descrições que eles nos propõem da melancolia e dos temperamentos que a ela se ligam, sem prejulgar sua intimidade com sua sintomatologia. (LAMBOTTE, 2000, p. 31)

Também aqui, não se trata de identificar sintomas específicos na trajetória biográfica de Van Gogh, nem de assumir a existência de um diagnóstico para o artista, mas apenas aceitar o que ele próprio tem a dizer sobre suas emoções.

\section{$2.2 \mathrm{O}$ artista se define como melancólico}

Com o objetivo de compreender melhor de que Van Gogh fala quando fala de melancolia, cabe retomar o histórico do uso desse termo em sua correspondência.

Uma das primeiras menções que Van Gogh faz à melancolia aparece em uma carta enviada a Theo em 9 de setembro de 1875 (Carta 46). Na época, aos 22 anos, trabalhava na filial da galeria Goupil \& Cie em Paris e ainda não tinha planos de se tornar um artista. A passagem é especialmente significativa, pois nela Van Gogh revela ao irmão uma frase dita pelo pai sobre o significado da melancolia na vida dos homens.

$\mathrm{Na}$ carta anterior, Theo anunciara a morte de um conhecido de ambos e mencionara que o sujeito havia lido certo livro do escritor Jules Michelet, chamado "L'Amour", sobre o qual conversara muito com Theo. Ele acrescentou que esse 
conhecido "amava muito a natureza e buscava nela uma melancolia quieta" (Carta 45). Theo provavelmente menciona o livro porque Vincent, no ano anterior, havia indicado essa mesma leitura para ele e para a irmã Willemien, dizendo que a obra tivera um caráter de revelação.

Existe uma melancolia quieta, certamente, graças a Deus, mas não sei se nós temos permissão para senti-la ainda, veja, eu digo nós: eu não mais do que você. Papai escreveu para mim recentemente: "A melancolia não machuca, mas nos faz ver as coisas com um olhar mais sagrado". Essa é a verdadeira "melancolia quieta", o ouro fino, mas nós ainda não chegamos tão longe, ainda há um longo caminho. Vamos esperar e rezar para que cheguemos tão longe e acredite em mim sempre. (Carta 46)

Parece, portanto, que nessa época Vincent via a "melancolia quieta" como um ideal de vida a ser alcançado a partir da evolução espiritual. Na mesma carta, Vincent recomenda enfaticamente que o irmão não leia mais o livro de Michelet, anteriormente tão recomendado por Vincent.

Sweetman interpreta que essa mudança de ideia sobre o autor se deve a uma grande desilusão amorosa sofrida por Vincent na Inglaterra. Se o livro "L'Amour" apresentava uma visão idealizada da mulher e de como deveria se desenvolver um relacionamento amoroso, sua experiência com o sexo oposto foi bem diferente. Apesar de não existirem cartas que registrem o fato, alguns biógrafos dizem que o artista fora rejeitado pela mulher por quem estava apaixonado. Esse acontecimento o levou à primeira grande crise emocional de Vincent, que assumiu uma postura retraída e taciturna e passou a ser relapso e desinteressado no trabalho na galeria de arte Goupil \& Cie.

A abordagem de um estado de espírito melancólico é feita de maneira particularmente insistente em uma carta escrita em junho de 1880 , no momento em que ele se encontra na região mineira do Borinage, na Bélgica. Aos 27 anos, Van Gogh participa de uma missão protestante nessa área extremamente pobre como meio de seguir seu propósito de se manter em uma vida religiosa, mesmo depois de ter falhado em entrar na faculdade de Teologia.

Na ocasião, Van Gogh está prestes a tomar a decisão de se tornar um artista. Nesta carta para o irmão, ele tenta justificar seu comportamento, que vem sendo alvo de muitas críticas por parte da família, que o vê como uma decepção. A vida 
missionária que tinha escolhido já era uma alternativa "menos digna" à carreira clerical de um pastor e mesmo essa função não estava sendo bem executada por Van Gogh. Aos olhos de seus supervisores, ele se degradava ao dar tudo o que possuía aos pobres mineiros e falhava na tarefa de evangelização.

É possível interpretar que a decisão de se tornar um artista resultou desse momento de reflexão profunda, angústia e melancolia.

Logo no início da carta, ele descreve seu sentimento ao sentar-se para escrevêla como um tanto melancólico e relutante. Ao falar de sua reação diante da falta que sentia dos livros e das pinturas de sua terra natal, estando ele no distante Borinage, ele introduz um conceito peculiar: o da "melancolia ativa".

Em vez de sucumbir ao sentimento de saudade da pátria, eu disse a mim mesmo, o país ou a pátria está em todos os lugares. Em vez de me entregar ao desespero, eu tirei vantagem da melancolia ativa enquanto eu tive força para atividade, em outras palavras, eu preferi a melancolia que espera e que aspira e que busca, em vez daquela que desespera, monótona e estagnada. (Carta 155)

Van Gogh descreve seu maior tormento como a dúvida sobre sua razão de viver, para que ele pode servir, em que poderia ser bom e útil. Sem uma resposta para esses questionamentos, ele diz sentir melancolia, desânimo e um vazio onde deveriam estar as amizades e a as afeições.

A figura da melancolia volta a aparecer na mesma carta, quando ele descreve a existência de dois tipos de pessoas ociosas. O primeiro tipo é o ocioso por preguiça ou fraqueza de caráter. O segundo, com o qual ele claramente se identifica, é o ocioso que tem dentro de si "um grande desejo de ação, que não faz nada porque acha impossível fazer qualquer coisa, estando ele aprisionado". Ele compara este último tipo com um passarinho preso em uma gaiola, que é acometido por um "ataque de melancolia" quando chega a época da migração, mesmo tendo tudo de que precisa dentro de sua gaiola.

É nesta carta - que costuma ser citada pelas biografias como um ponto crucial na tomada de decisão rumo à vida artística - que Van Gogh demonstra a certeza de que têm um propósito maior na vida. 
Um sujeito como esse nem sempre sabe o que poderia fazer, mas sente instintivamente, eu sou bom em alguma coisa! Eu sinto que tenho uma razão de ser! Eu sei que poderia ser um homem totalmente diferente! Em que então eu poderia ser útil, a que eu poderia servir! Há alguma coisa dentro de mim, o que é isso então! (Carta 155)

Em carta de novembro de 1881, quando passava uma temporada na casa dos pais, em Etten, ele volta a falar sobre a melancolia que sente. Na época, logo depois de um episódio no qual fora rejeitado pela prima Kee Vos ao declarar seu amor a ela, Van Gogh fala na importância do trabalho duro para superar uma fase ruim.

Talvez não seja uma coisa ruim eu ter vivido tanto tempo no 'subterrâneo', por assim dizer. Que eu seja aquele 'que tem estado para baixo'. Mas agora eu não preciso retornar ao abismo e faria bem, eu penso, em arremessar toda a melancolia aos ventos e viver a vida um pouco mais livremente e alegremente com os pés no chão. $E$ reviver relações antigas tanto quanto possível e começar novas. (Carta 189)

Ele se define novamente como melancólico em carta de julho de 1882, quando tenta explicar ao irmão Theo a natureza de seu relacionamento com a prostituta Sien Hoornik, em oposição à paixão que desenvolveu, no ano anterior, pela prima Kee Vos, por quem foi rejeitado. Aos 29 anos, ele já vive como um artista.

Não imagine que eu pense ser perfeito - ou que eu acredite que não é minha culpa que tantas pessoas me considerem um personagem desagradável. Eu estou com frequência terrivelmente e irreparavelmente melancólico, irritável - ansiando por simpatia como se com uma espécie de fome e sede - eu me torno indiferente, afiado e às vezes até derramo óleo sobre a chama se não recebo simpatia. Eu não gosto de companhia, e lidar com as pessoas, falar com elas, é frequentemente doloroso e difícil para mim. (Carta 244)

Van Gogh demonstra considerar que a melancolia é uma condição natural de todos os homens. Essa visão é expressada em carta escrita em março de 1883 a Theo:

Na minha opinião, todos nós temos momentos de melancolia, de estresse e de ansiedade, em uma extensão maior ou menor, e isso é uma condição de toda vida humana autoconsciente. Alguns aparentemente não têm autoconsciência. Mas aqueles que têm momentos assim, apesar de às vezes em um estado de ansiedade, não são desafortunados por causa disso, e nada de incomum está acontecendo com eles. E às vezes há uma solução, às vezes a nova energia interna vem e a pessoa se levanta a partir dela, até que talvez finalmente, um belo dia, a pessoa não mais se levanta - assim seja - mas 
não há nada de incomum nisso e, eu repito, é inerente à vida humana, na minha opinião. (Carta 327)

A referência a uma melancolia boa volta a aparecer em carta de setembro de 1883. Depois de deixar a companheira, Sien, em uma passagem pelo interior da Holanda, Van Gogh descreve ter visto "figuras esplêndidas" no campo. "E a melancolia que as coisas têm no geral é de um tipo saudável, como nos desenhos de Millet" (Carta 386).

Em alguns momentos da correspondência, ele se refere ao trabalho e à melancolia como situações antagônicas. Em carta de junho de 1882, por exemplo, ele se questiona que motivos teria para a melancolia e acrescenta, logo em seguida: "Eu tenho meu trabalho, afinal de contas, e meu desfrute dele. Desde quando há alguma necessidade de vacilar ou hesitar ou ter o coração fraco?" (Carta 234).

Já em setembro de 1883, ele afirma que seu trabalho Ihe proporciona uma fuga da melancolia e que, quando o trabalho não se desenvolve, ele é acometido por esse sentimento. "E eu fico tão intoleravelmente melancólico quando o trabalho não me proporciona uma distração, como você vai entender, eu devo trabalhar e trabalhar de forma constante - esquecer-me no trabalho, caso contrário eu ficaria oprimido" (Carta 391).

Em certo ponto, em outubro de 1883, ao evocar sua melancolia, Van Gogh dá um conselho ao irmão Theo que mais parece ser um conselho para si mesmo.

(...) fazer-se escasso ou desaparecer - nem você nem eu podemos jamais fazer isso, não mais do que um suicídio. Eu mesmo tenho meus momentos de grande melancolia, mas o pensamento: desapareça, façase escasso, deve, eu repito, ser visto por mim e por você como não benéfico a nós. (Carta 401)

Dessa forma, é possível observar que, se em determinados momentos a melancolia é vista como uma qualidade, que leva a percepções mais profundas sobre o mundo e que o inspira na busca de sua verdadeira função na vida, em outras ela é vista como algo que precisa ser atirado para fora, algo que o torna menos digno diante de outras pessoas.

Se em alguns momentos, a melancolia aparece como um impulso para seu trabalho como artista, em outros ela aparece em oposição ao trabalho, como o 
sentimento que o acomete quando seu trabalho não está sendo executado de maneira satisfatória.

\subsection{Jornada até o sul da França}

O caminho de Zundert - vilarejo holandês onde Van Gogh nasceu - até Arles onde o artista pintou algumas de suas principais telas - foi longo e tortuoso. Van Gogh passou por sucessivos deslocamentos ao longo de seus 37 anos. Depois que saiu da casa dos pais, aos 16 anos, para trabalhar na galeria de arte de seu tio, em Haia, não permaneceu mais do que quatro anos seguidos vivendo na mesma cidade.

As mudanças de casa refletiam os conflitos internos do artista. Apesar de sempre ter sentido que tinha um dom missionário, demorou até escolher a pintura como sua verdadeira missão. Durante muito tempo, acreditou ter vocação para a religião e sofreu muitas frustrações por não conseguir por em prática a atividade de pastor.

Van Gogh nasceu em 1853, exatamente um ano depois de seu irmão, de mesmo nome, ter nascido morto em 30 de março de 1852. A mãe, Anna, e o pai, Theodorus, ainda estavam de luto na ocasião de seu nascimento.

Theodorus era o pastor da Igreja Reformada Holandesa no vilarejo de Zundert, na província de Brabant, na Holanda, perto da fronteira com a Bélgica. Em Brabant, a maior parte da população era católica, o que fazia com que o pastor protestante tivesse pouco prestígio. Anna era uma artista amadora dedicada aos cuidados da família.

A tradicional família Van Gogh era formada por clérigos, marchands e oficiais. Um dos membros mais abastados da família era o tio de Vincent, também chamado Vincent Willem van Gogh, o tio Cent. Foi tio Cent quem introduziu os irmãos Vincent e Theo no mundo do comércio de arte. Ele era sócio da rede de galerias de arte Goupil, que tinha filiais em várias cidades da Europa.

Aos 16 anos, Van Gogh foi para Haia trabalhar em uma das unidades da Goupil. Lá, viveu durante quatro anos e passou a absorver tudo o que se relacionasse à arte. Ele gostava, especialmente, das pinturas da escola de Barbizon, cujo princípio era 
pintar diretamente da natureza, ao ar livre. Essa corrente rejeitava os temas clássicos e religiosos valorizados pelas academias. Lá passou a admirar Millet e também conheceu o pintor Anton Mauve, mestre na arte de captar a natureza de modo imediato.

Nessa época, Van Gogh continuava a ter aulas sobre a Bíblia e sentia compaixão pelos pobres e desvalidos, daí a admiração pela pintura de Millet, que retratava tão bem a vida dos camponeses.

A correspondência com Theo começou em 1872, depois de uma visita do irmão a Haia, ocasião em que tiveram a oportunidade de ficar mais próximos. Em 1873 foi enviado para a sucursal de Londres da Goupil, como uma promoção de seu cargo. Lá, passou a morar em um quarto a alugado e, segundo alguns biógrafos, apaixonou-se pela filha de sua senhoria, sofrendo a primeira decepção amorosa ao descobrir que a moça ficara noiva de outro homem. Passou da euforia para a tristeza e sua reação exagerada assustou toda a família.

Em 1874, foi enviado para a sucursal da Goupil em Paris, em uma tentativa da direção da galeria de fazê-lo motivar-se novamente pelo trabalho. Lá ficou até 1876, quando finalmente foi despedido. Seu estado de espírito não permitia que se dedicasse ao trabalho e ele passara a ser negligente com suas funções. Apesar de ser a época em que ocorriam as primeiras exposições dos impressionistas em Paris, van Gogh não entrou em contato com esses trabalhos na ocasião. Estava alheio a toda a efervescência cultural parisiense.

Em seguida, mudou-se para Ramsgate, na Inglaterra, onde passou a dar aulas como professor voluntário e, depois, mudou-se para Isleworth com a função de assistente de um pastor. Preocupados com o futuro de Vincent, seus pais o chamaram de volta para casa e, em 1877, conseguiram para ele um emprego em uma livraria na cidade de Dordrecht, perto de Roterdã, na Holanda. No mesmo ano, ele decidiu que queria ingressar na faculdade de Teologia. Seu sonho era seguir a profissão do pai e tornar-se um pastor. A família se mobilizou e o jovem foi a Amsterdã viver com um tio e estudar para os testes.

Depois de ser reprovado e passar um período como missionário religioso na região mineradora do Borinage, uma das mais pobres da Europa, finalmente decidiu dedicar-se à pintura. De 1880 a 1885, passou por Bruxelas, onde estudou pintura, por 
Etten, onde então viviam os pais, novamente por Haia, para trabalhar no estúdio do pintor Anton Mauve, e por Nuenen, de volta à casa dos pais.

Em 1885, mudou-se repentinamente para Paris para viver com o irmão Theo, onde finalmente entrou em contato com toda a cena artística impressionista. Lá, conheceu Camille Pissarro, Henri de Toulouse-Lautrec, Émile Bernard, Paul Gauguin, Paul Signac, entre outros. Foi lá também que seu entusiasmo pelo Japão e pelas estampas japonesas atingiu o ápice. Mas a agitação urbana e o consumo excessivo da bebida da moda, o absinto, fizeram mal ao pintor.

Em 1888, decidiu que era hora de partir novamente. Mas, dessa vez, sua motivação foi quase puramente estética. Além do fato de que desejava fugir do ambiente conturbado de Paris, a ida para o sul se apresentava como uma oportunidade de conhecer as cores mais quentes da paisagem da região, como descreve Sweetman:

A primeira ideia de Vincent era ir para Marselha, a cidade natal de Monticelli, onde supunha que se originara algo do admirado colorido do artista. Então John Peter Russel Ihe falou sobre Arles e seus arredores, onde um amigo seu, o americano Dodge MacKnight, estava pintando. Pareceu-lhe que poderia ser um bom lugar para passar algum tempo antes de seguir para Marselha; afinal, Monticelli tinha pintado suas marinhas na vila próxima de Les Saintes-Maries-de-la-Mer. (SWEETMAN, 1993, p. 204)

A motivação da escolha pela cidade de Arles é motivo de controvérsia entre os biógrafos de Vincent. Para Naifeh e Smith (2012), Van Gogh escolheu Arles como exílio voluntário de Paris não pelo calor, nem pela luz, nem pelas mulheres. A escolha priorizou, segundo os autores, o fato de que nessa cidade, o artista poderia se entregar ao trabalho sem outras distrações:

Se tivesse ido para o lendário Sul da França - o Midi - em busca de um clima mais quente, certamente teria ficado no trem e seguiria mais ao sul. (Pensou em ir até Tânger.) Em vez disso, desembarcou numa neve que lhe cobria os sapatos e se arrastou pelo inverno mais frio dos últimos dez anos em Arles, procurando um quarto para alugar. Se tivesse ido procurar a 'luz brilhante do Midi' prometida por Lautrec e Signac, não teria escolhido como tema de sua primeira pintura um açougue numa travessa de Arles - uma cena urbana sem céu e sem sol que poderia encontrar em qualquer canto de Montmartre. Se tivesse ido apenas por causa das mulheres -, teria continuado até Marselha, apenas oitenta quilômetros adiante: o tipo de cidade portuária agitada, como 
Antuérpia, onde sempre havia todas as espécies possíveis de mulheres. (NAIFEH e SMITH, 2012, p. 660)

De qualquer forma, a expectativa em relação à viagem era realmente alta, como ocorrera anteriormente em suas tantas mudanças de cidade. Sweetman assim descreve o entusiasmo que deve ter tomado conta de Van Gogh nesse momento: "Como o Midi deve ser maravilhoso, com o sol da Provença, as cores quentes. Melhor ainda, a vida seria barata e outros artistas certamente viriam se juntar a ele assim que tivesse montado seu ateliê (...)" (SWEETMAN, 1993, p. 204). Ronald Pickvance (1985) observa que Vincent deve à leitura do livro "Tartarin de Tarascon", romance satírico de Alphonse Daudet que retrata de forma caricatural o povo do sul da França, a visão de um povo provençal alegre e jovial. Para o autor, Vincent depositava em Arles o sonho de um futuro luminoso feito de sol, calor, saúde, entusiasmo e vida em comunidade, transformando a cidade em uma espécie de "paraíso exótico".

O idealista Vincent tinha o sonho de lá formar uma colônia de artistas. A ida de Gauguin para Arles foi a primeira e a única etapa desse plano a se concretizar. Dois meses depois da chegada do amigo, uma forte crise se abateu sobre ele, o que resultou no trágico episódio da orelha cortada e em sua internação no Hôtel Dieu, o hospital de Arles.

\section{Diagnósticos}

Para a sociedade da época e mesmo para membros da família, Van Gogh era simplesmente louco. "Lá está aquele doido outra vez", diziam os meninos de Nuenen, cidade onde viveu com os pais entre 1883 e 1885, quando viam o pintor buscando o lugar ideal para armar seu cavalete no meio do campo (NAIFEH; SMITH, 2012, p. 512).

Os pais viram indícios de loucura e irresponsabilidade no fanatismo religioso da juventude, na posterior negação de todas as formas de religião, na maneira extravagante de se vestir e nas desastradas investidas amorosas. O pai chegou a se indagar sobre como poderia obter um certificado de que o filho era insano, quando soube que ele vivia com uma prostituta na cidade de Haia (SWEETMAN, 1993).

Após a grave crise que o levou à automutilação, o primeiro diagnóstico oficial que recebeu no hospital de Arles, o Hôtel Dieu, foi de "mania aguda com delírio generalizado". O médico arlesiano Félix Rey, de quem Van Gogh pintou um retrato, 
levantou suspeitas de que ele sofresse de "uma espécie de epilepsia". Em seguida, no Hospício de Saint-Paul-de-Mausole, em Saint Remy, o médico Théophile Peyron acatou a opinião de Rey, de que Van Gogh sofria de acessos epilépticos. A hipótese foi reforçada quando o pintor afirmou existirem outros casos de epilepsia na família.

Já em Auvers-sur-Oise, cidade onde Van Gogh viveu seus últimos meses, o médico Paul Gachet propôs um tratamento "estimulante" caso ele caísse novamente em depressão. Mostrando-se surpreendentemente otimista, parece não ter visto gravidade no caso de van Gogh.

Depois de sua morte, muitos autores já se dispuseram a responder a questão sobre qual seria a doença mental que teria afligido van Gogh nos últimos anos de sua vida, senão durante sua vida inteira. As conclusões contemplam possibilidades como sífilis, esquizofrenia, epilepsia, alcoolismo, transtorno bipolar, envenenamento por tintas, entre outras hipóteses.

Alguém poderia pensar que a descrição eloquente de Van Gogh de seus sintomas teria produzido uma concepção clara de sua doença. Ainda assim, para nenhuma outra figura histórica tantos diagnósticos foram propostos; diz-se que mais de 100 foram encaminhados desde a morte de Van Gogh, de sífilis à doença de Ménière. (SANDBLOM, 1993, tradução nossa)

É interessante observar que, enquanto Philip Sandblom, na crítica do livro de Wilfred Arnold "Vincent van Gogh: Chemicals, Crises, and Creativity", publicada no periódico "The New England Journal of Medicine", caracteriza a descrição que Van Gogh faz de seus próprios sintomas como "eloquente", Nagera percebe justamente o contrário:

Para os efeitos deste estudo, é também lamentável que Vincent se mostrara relutante em escrever com detalhe sobre sua doença. Quando em algumas ocasiões se refere a ela, o faz em termos bem vagos e gerais; entretanto, é muito preciso quando pede a seu irmão que não queira saber detalhes de sua enfermidade porque, em verdade, preferiria não falar nem pensar nela. (NAGERA, 1980, p. 124)

Em artigo publicado em 2002 no periódico "The American Journal of Psychiatry", o médico Dietrich Blumer contesta a conclusão a que chegara Henri Gastaut em estudo publicado em 1956. Gastaut confirmara o diagnóstico dado a Van 
Gogh por seus médicos na época, ao afirmar que ele havia desenvolvido uma "epilepsia precipitada pelo uso de absinto, na presença de lesão límbica anterior" (BLUMER, 2002).

Blumer chama a atenção para o fato de que, antes da crise de Arles, Van Gogh havia sofrido dois episódios distintos de depressão reativa, o que demonstra que havia "claros aspectos bipolares em seu histórico". "Ambos os episódios de depressão foram seguidos por períodos prolongados de energia e entusiasmo crescentes, primeiro como evangelista, depois como artista" (BLUMER, 2002, tradução nossa).

Desta forma, Blumer sugere que a doença mental de Van Gogh possa ter sido o transtorno bipolar. "Um histórico de períodos prolongados de níveis extremamente altos de energia, entusiasmo e produtividade alternando com episódios de depressão não é incomum entre escritores e artistas, e a fase hipomaníaca frequentemente não é identificada" (BLUMER, 2002). Trata-se de uma das mais recentes investidas médicas com o intuito de desvendar o segredo por trás das crises de Van Gogh.

Outros autores defendem que tais hipóteses provêm de uma cultura "medicalizante" e que o único mal de que Van Gogh sofria era sua própria genialidade. É a teoria de Antonin Artaud, que dispara uma crítica ácida sobre a psiquiatria em "Van Gogh: O Suicida da Sociedade": "Foi assim que uma sociedade deteriorada inventou a psiquiatria para se defender das indagações de certas mentes superiores, cuja capacidade de adivinhar a incomodava" (ARTAUD, 2003). O autor ainda reitera que não havia nenhum sinal de loucura nos quadros de Van Gogh: "Não há fantasmas nos quadros de Van Gogh, não há visões, nada de alucinações. É a verdade tórrida de um sol das duas da tarde".

Esta pesquisa reconhece a impossibilidade de se chegar com precisão a um diagnóstico póstumo de Van Gogh. No entanto, qualquer que tenha sido o mal que o acometera durante a vida, é incontestável que ele tenha passado por períodos marcados de depressão e melancolia, e por períodos de euforia e grande entusiasmo, fato atestado não apenas por médicos e biógrafos, mas por suas próprias palavras ao longo de sua intensa correspondência.

É por esse motivo que escolhi abordar, neste trabalho, os sentimentos de melancolia e de euforia no artista, independentemente de eles terem sido provocados 
por uma saúde mental abalada por alguma doença ou simplesmente por uma personalidade excessivamente sensível diante das vicissitudes da vida. 
3 A produção nos períodos melancólicos

A leitura das cartas de Van Gogh permite identificar sinais que apontam para seu estado de espírito no momento em que as escreve. Neste capítulo, apresento uma revisão sobre a descrição que o próprio artista faz de suas emoções ao longo do período analisado: entre fevereiro e dezembro de 1888. Desta forma, distinguem-se as diferentes fases emocionais experimentadas pelo pintor nos primeiros 10 meses em que viveu na cidade de Arles. O capítulo também traz a análise de oito pinturas produzidas durante esse período e selecionadas com o objetivo de verificar de que maneira seu estado de espírito pode ter interferido em sua produção artística.

\subsection{As cartas revelam seus sentimentos}

Van Gogh era um leitor voraz e, entre os pintores de sua geração, era um dos que mais valorizava a literatura. É a ele que o artista Emile Bernard recorria quando tinha vontade de submeter sua poesia à crítica de um de seus amigos. Em uma carta enviada a Bernard que continha justamente os comentários e críticas a respeito de um de seus sonetos, Van Gogh demonstra o quanto as palavras eram importantes para ele:

Há tantas pessoas, principalmente entre nossos colegas, que imaginam que as palavras não são nada. Pelo contrário - você não acha - é tão interessante e tão difícil escrever bem alguma coisa quanto pintar alguma coisa. Há a arte das linhas e das cores, mas a arte das palavras é e continuará sendo tão importante quanto a outra. (carta 599)

Para Paolo Lecaldano, devemos a Van Gogh duas obras capitais: uma plástica composta de 879 pinturas, 1756 desenhos e 10 gravuras - e outra literária. Ele descreve a correspondência como "uma avaliação quase diária de uma vida pobre em eventos exteriores, mas de introspecção incessante, efusão de uma solidão irremediável, confissão sem remorso, revelação de um mundo interior sem limites" (LECALDANO, 1971, p. 5, tradução nossa). 
É justamente a observação cuidadosa das palavras da van Gogh que vai nos conduzir a uma jornada em busca das emoções do pintor. Saber com precisão o que ele sentiu em cada fase de sua estadia na região do Midi, na França, é o objetivo desta empreitada.

Este trabalho propõe a identificação de distintas fases emocionais por meio da correspondência do artista. Essas fases vêm delimitadas pelas datas daquelas cartas que representam as principais transições, o que ajuda a estabelecer uma referência mais precisa para análises posteriores. Essa simplificação, no entanto, foi adotada como recurso metodológico, reconhecendo-se que essas transições provavelmente se deram de maneira muito mais fluida: as datas são meros pontos de referência.

Cabe esclarecer ainda que, se este capítulo recorre com frequência à citação de trechos da correspondência de Van Gogh, é porque é preciso demonstrar ao leitor de que forma foi possível identificar esses estados emocionais. Para cumprir esse objetivo, nada melhor do que invocar as próprias palavras escolhidas pelo artista para descrever seus sentimentos em relação a si mesmo e em relação ao mundo.

\section{'Ataque de melancolia': a chegada a Arles (20/2 a 15/3)}

Se Van Gogh esperava encontrar no sul o "paraíso na terra" descrito por Toulouse-Lautrec ${ }^{5}$, as cores quentes como vistas nas estampas japonesas ou o maravilhoso "sol da Provença", ele deve ter sofrido grande decepção com o que viu ao se aproximar, de trem, da estação de Arles. Naquele dia 20 de fevereiro, a cidade estava coberta de neve.

Do trem, uma das primeiras visões de Van Gogh em Arles provavelmente foram as ruínas do cemitério romano de Alyscamps. Assim presume Sweetman, tendo em vista que a linha férrea passava próxima ao local:

\footnotetext{
${ }^{5} \mathrm{O}$ artista Henri de Toulouse-Lautrec, de quem Van Gogh se tornara amigo em Paris, "descrevera a Provença de sua infância de um modo que sugeria o paraíso na terra" (SWEETMAN, 1993). O biógrafo sugere que essa descrição entusiasmada havia se somado a outros fatores para que Van Gogh decidisse finalmente mudar-se para o sul. Os dois artistas tinham se tornado próximos nesse período, como descreve Sweetman: "O atarracado aristocrata, vestido de preto, de rosto carnudo e olhos bulbosos a espiar através de um pincenê, e o emaciado holandês em seu avental de trabalhador, de ombros caídos e olhar desconfiado, logo se tornaram parceiros habituais nos bares e cabarés de Montmartre." (SWEETMAN, 1993)
} 
A estrada de ferro era considerada tão vantajosa, prometia tanta prosperidade, que se permitiu que a linha profanasse o que o burgo tinha de mais antigo, o Alyscamps, ou "Champs Elysées", um cemitério pagão e cristão primitivo, onde imponentes sarcófagos se alinhavam ao longo do que fora outrora uma via longa e lúgubre, antiquíssima. Depois que a linha férrea que seguia para o sul, rumo a Marselha, seccionou o caminho ao meio, o que restou dele foi reduzido a um pequeno jardim público, além do qual se erguiam mais fábricas e chaminés. $O$ velho e o novo conviviam desconfortavelmente ali, mais ainda em razão da presença de cerca de quinhentos a oitocentos trabalhadores italianos imigrantes, atraídos pelos novos empregos, que a população nativa desprezava e chamava de "macacos saboianos". (SWEETMAN, 1993, p. 207)

Apesar de buscar um contato mais próximo com a natureza, Van Gogh não deve ter previsto que os campos ao redor da cidade seriam tão agrestes.

A cidade ficava à margem do Grande Ródano, logo abaixo do ponto em que dele se separava o Pequeno Ródano, o que punha Arles no ápice do triângulo que formava então a região inculta da Camargue, uma área plana e baixa de lagunas de água salgada e charcos, que ainda abrigava bandos de cavalos selvagens e touros não domesticados, e cujos céus eram cortados por inesperadas revoadas de flamingos. Os campos mais próximos, o Crau, eram pantanosos e exibiam afloramentos de rocha, embora a construção de canais os tivesse transformado em grande parte em boa terra arável. (SWEETMAN, 1993, p. 206)

É provável que esse cenário de ruínas e natureza excessivamente selvagem tenha surpreendido negativamente o artista, mas ele não estava disposto a compartilhar tamanha decepção, pelo menos não tão cedo. O tom das primeiras cartas escritas em Arles é de discreto otimismo em relação à nova cidade. Ele diz vagamente que "o sangue volta a correr em suas veias" e preocupa-se em reafirmar a necessidade de ter se mudado de Paris, local onde sua saúde e sua paz de espírito estavam se esgotando. Deixa transparecer apenas alguns lamentos em relação ao custo de vida na cidade, mais alto do que esperava.

A primeira vez em que mencionará explicitamente os sentimentos que teve logo ao chegar a Arles será posteriormente, em uma carta a Theo enviada em 4 de maio. Referindo-se ao momento em que acabara de deixar a Paris - onde sua saúde se deteriorara diante do exagero do cosumo de bebidas alcoólicas - e começara sua nova vida em Arles, ele diz: 
Quando eu parei de beber, quando eu parei de fumar tanto, quando eu recomecei a refletir em vez de procurar não pensar - meu Deus, quanta melancolia e quanto desânimo. $O$ trabalho nesta natureza magnífica me sustentou a moral, mas mesmo aqui, depois de alguns esforços, as forças me falharam. (Carta 603)

Em uma carta posterior, a Emile Bernard, escrita em 19 de junho de 1888, ele especifica que o período de seu "ataque de melancolia" se estendeu por quatro semanas a partir do momento em que chegou a Arles.

Somente ao final de quatro semanas aqui [em Arles] é que as coisas passaram a funcionar, mas, meu caro amigo, nessa época eu tive um ataque de melancolia como o que você tem agora, pelo qual eu teria sofrido tanto quanto você se não fosse o fato de eu tê-la saudado com grande prazer como sinal de que eu iria me curar - o que também aconteceu. (carta 628)

Ele volta a mencionar essa crise inicial em pelo menos outras três cartas. Em 22 de julho, envia a Theo uma carta em que diz que, apesar de estar se sentindo melhor, a crise que teve ao chegar a Arles mostrou que ele não poderia se dar ao luxo de fazer planos ou ter grandes esperanças de uma vida melhor:

Depois da crise pela qual passei ao vir para cá, eu não posso mais fazer planos ou qualquer coisa, eu estou melhor agora decididamente, mas a esperança e o desejo de alcançar estão quebrados e eu trabalho por necessidade, para não sofrer tanto moralmente, para me distrair. (Carta 645)

Enquanto estava no auge de sua produção artística do período de Arles, em meados de setembro, Van Gogh voltou a lembrar dos dias difíceis que enfrentou nas primeiras semanas vivendo na cidade. Desta vez, ele se refere à sua capacidade artística de "atacar" um tema e se entregar à natureza e às paisagens da região em suas telas. Assim ele descreve sua mudança, em carta enviada ao irmão Theo em 18 de setembro: "Eu começo a me sentir de forma totalmente diferente do que quando cheguei aqui, eu não duvido mais, eu não hesito mais ao atacar uma coisa e isso ainda poderia crescer" (Carta 683).

O tema do sofrimento enfrentado na chegada a Arles reaparece, inclusive, na última carta que escreve ao irmão antes do ataque que o levou a cortar a própria orelha, escrita em 18 de dezembro: “(...) ao chegar aqui no inverno passado, cansado e 
quase esgotado cerebralmente, antes de poder começar a me refazer, também sofri um pouco internamente" (carta 726).

\section{Pomares em flor: 'o trabalho me pegou com força' (16/3 a 9/4)}

Depois da crise vivida por Van Gogh nos primeiros dias em Arles, houve uma mudança em sua relação com a cidade. Quando as primeiras amendoeiras começaram a florescer, o artista passou a produzir intensamente, inspirado pela paisagem que ele identificava com o seu tão admirado Japão. Esse tipo de observação começa a aparecer em uma carta para Theo de 16 de março:

\footnotetext{
Mas, meu querido irmão - você sabe, eu me sinto no Japão. Eu não digo nada mais que isso, e observe que eu ainda não vi nada em seu esplendor habitual. É por isso (mesmo estando preocupado que, no momento, as despesas são grandes e as pinturas de nenhum valor), é por isso que eu não me desespero pelo sucesso da empreitada de fazer uma longa jornada pelo sul. Aqui eu vejo coisas novas, eu aprendo, e sendo tratado com um pouco de gentileza, meu corpo não me recusa seus serviços. (Carta 585 )
}

Como se estivesse enlevado pela paisagem, ele repete em outras cartas seu encantamento pelas novas cores que observa na cidade. Para Emile Bernard, Van Gogh cita que a região é envolvida por uma "cor alegre", o que pode refletir uma tendência de seu próprio estado de espírito.

\footnotetext{
Tendo prometido escrever para você, quero começar dizendo que o país me parece tão belo quanto o Japão pela claridade da atmosfera e pelos efeitos da cor alegre. As extensões de água formam manchas de um belo esmeralda e de um rico azul nas paisagens, assim como vemos nas estampas japonesas. Pores do sol laranja pálido fazem parecer azuis os campos - os sóis amarelos esplêndidos (...) E isso também, sem dúvida, se alegrará ainda mais no verão. (Carta 587)
}

À irmã Willemien, em carta de 30 de março, diz que não se arrepende de ter ido para o sul da França, já que lá encontrou uma "natureza deslumbrante" (Carta 590). Na mesma mensagem, afirma que "o trabalho o pegou com força".

A vontade de aproveitar as cores da paisagem florida para pintar o máximo de telas é tamanha que, mesmo nos dias de vento, em que a pintura ao ar livre pode se tornar penosa, Van Gogh encontra uma estratégia para não precisar parar de trabalhar. "Eu tenho muita dificuldade em pintar por causa do vento, mas eu prendo 
meu cavalete com estacas cravadas na terra e trabalho de qualquer maneira, é bonito demais" (Carta 591).

A produção das pinturas que retratam os pomares em flor de Arles atinge seu auge no início do mês de abril, de acordo com as descrições que o artista faz de suas atividades: "Estou em uma fúria de trabalho porque as árvores estão em flor e eu queria fazer um pomar da Provença de uma alegria tremenda" (Carta 592).

A "fúria de trabalho" vem acompanhada por uma grande agitação, um sentimento de urgência, uma intempestividade que, de certa forma, lhe traz dificuldades para o cotidiano.

"Escrever a você com a cabeça tranquila apresenta sérias dificuldades, ontem escrevi algumas cartas que eu destruí posteriormente", diz a Theo (Carta 592).

Em carta a Theo de 5 de abril, apenas dois dias depois da última correspondência, Van Gogh encomenda uma lista de tintas e produtos para pintura, que devem ser entregues com urgência para que ele não perca nem um dia da temporada dos pomares em flor.

"Eu tenho um novo pomar para você - mas, em nome de Deus, faça com que eu receba as cores sem atraso. A temporada dos pomares em flor é tão fugaz e você sabe que esses motivos são aqueles que alegram todo mundo" (Carta 593).

Em 9 de abril, Van Gogh novamente menciona sua fase de alta produtividade ao retratar os pomares. Ele sabe que, trabalhando dessa forma, também impõe um peso financeiro ao irmão, já que gasta rapidamente as tintas e telas compradas ou financiadas por Theo:

O mês vai ser difícil para você e para mim, mas mesmo assim, se for possível, é nossa vantagem fazer o máximo possível de pomares em flor. Eu estou atualmente bem encaminhado e ainda preciso fazer mais 10 , me parece, do mesmo motivo. Você sabe que eu sou inconstante no meu trabalho e que esta fúria de pintar os pomares não durará para sempre. - Depois, serão possivelmente as arenas de touradas. (Carta 594)

Na mesma carta, ele menciona que está sofrendo no presente, apesar de sentir que o "sangue está se refazendo". Trata-se de um sinal de que o período da alegria diante das cores e das paisagens floridas começa a chegar ao fim. Na carta seguinte, a 
palavra "melancolia" volta a aparecer em seus escritos, marcando um novo declínio em seu estado de espírito.

"No presente, eu sofro muito alguns dias, mas isso não me inquieta nem um pouco porque não é nada mais do que a reação a este inverno que não foi comum. - E o sangue se refaz, é o principal" (Carta 594).

A correspondência referente ao período da vida de Van Gogh marcado pela pintura dos pomares em flor - neste trabalho delimitado pelas cartas de 16 de março e de 9 de abril - está cheio de referências à alegria (ou gaieté, no original em francês): as cores são alegres, os pomares são de uma alegria imensa e os motivos são aqueles capazes de alegrar o espectador.

Quando Van Gogh expressa seu desejo de fazer uma homenagem ao pintor Anton Mauve ${ }^{6}$, que morrera em fevereiro, essa necessidade de alegria volta a ser citada. Ele diz a Theo que escolheu seu melhor estudo feito em Arles para homenagear o mestre Mauve. "Parecia-me que em memória de Mauve precisávamos de algo que fosse tanto afetuoso quanto alegre, e não um estudo em um tom mais sério do que isso" (Carta 591).

Não é possível determinar se as repetidas menções à alegria observadas nesse período devem-se à possibilidade de ele estar de fato experimentando essa sensação ou se podem ser atribuídas a uma intenção de se sentir alegre e proporcionar essa experiência a outras pessoas. De qualquer forma, a narrativa construída pelo pintor em sua correspondência deste período apresenta uma clara oposição àquela observada no período anterior. Seja a alegria uma sensação de fato ou uma intenção, é ela quem caracteriza esta segunda etapa da estadia de Van Gogh em Arles.

\section{'Sentimento melancólico de não se encontrar na vida real' (10/4 a 25/5)}

\footnotetext{
${ }^{6}$ Van Gogh conheceu o pintor Anton Mauve em 1870, muito antes de pensar em se tornar um artista, enquanto trabalhava na galeria de arte Goupil, em Haia. Aproximando-se do ideal de captar a natureza de forma imediata, Mauve representava, para Van Gogh, "uma ponte entre o tipo de trabalho em meio ao qual crescera, na Holanda, e a nova arte que descobriria mais tarde em Paris (SWEETMAN, 1993, p. 34). Mauve, que "também sofria de acessos agudos e inexplicáveis de melancolia" casou-se com a prima de Van Gogh, Jet. No fim de 1881, Van Gogh voltou a encontrar-se com Mauve, que passou a dar conselhos sobre pintura e desempenhar o papel de professor. Foi com o incentivo de Mauve que Van Gogh começou a usar cores; antes de suas aulas, ele se limitava às ilustrações em preto e branco.
} 
Mal as últimas pétalas das árvores de fruta caíram ao chão, deixando seu pincel desocupado, os demônios do passado vieram ocupar de roldão o vazio. O clima meridional não o revigorou e a saúde continuou a declinar. Era assolado por distúrbios estomacais, febres e uma fraqueza generalizada. Entre chagas na boca, dores de dente e problemas digestivos, comer era 'um verdadeiro suplício', e voltou a flertar com a ideia de passar fome. Queixava-se de acessos de distração e confusão mental, com faíscas de pânico nas cartas quando olhava o destino de outros pintores, como De Braekeleer e Monticelli, reduzidos a 'destroços irrecuperáveis' devido a 'doenças do cérebro' - código para o mal que afligia os dois irmãos, a sífilis. (NAIFEH e SMITH, 2012, p. 667)

A partir deste momento, Van Gogh começa a descrever um sentimento de melancolia por não viver a vida real. Ele considera que os artistas vivem o mundo da arte, dos quadros, das cores e das pinceladas, renegando, desta forma, a "vida de verdade". É como se, para ele, ao escolher dedicar-se à arte, um artista estivesse abdicando dos relacionamentos e da estabilidade de se casar e de ter uma família.

É possível que ele tenha começado a sentir, pela primeira vez desde que chegou a Arles, o peso da solidão, de estar longe do irmão e dos amigos e de não conseguir criar vínculos na nova cidade. Talvez por isso Van Gogh insista tanto, nas cartas enviadas a Theo neste período, que os irmãos se esforcem para retomar as amizades da Holanda, como um retorno às raízes.

\begin{abstract}
Ah, me parece cada vez mais que as pessoas são as raízes de tudo e, embora permaneça para sempre um sentimento melancólico de não se encontrar na vida real - no sentido de que seria melhor trabalhar na própria carne do que nas cores ou no gesso, no sentido em que seria melhor fabricar crianças do que fabricar quadros ou fazer negócios - no entanto você se sente vivo quando pensa que tem amigos que, eles mesmos, também não estão na vida real. (Carta 595)
\end{abstract}

Van Gogh começa a ver diante de si um futuro "cheio de dificuldades" e passa a se perguntar se esses obstáculos não seriam mais fortes do que ele próprio (Carta 602). Nesta mesma carta, ele conta ter alugado o edifício que se tornaria a célebre "casa amarela", para servir de ateliê e de moradia. "Desta forma, garanto minha independência das picuinhas das pensões, que são ruinosas e me entristecem."7

\footnotetext{
${ }^{7}$ Ao chegar a Arles, Van Gogh hospedou-se no Restaurant Carrel, que tinha quartos para alugar no segundo pavimento. Van Gogh foi surpreendido pelo fato de, apesar de o local ser modesto, a comida e a hospedagem não serem mais baratas do que em Paris (SWEETMAN, 1993, p. 216). Ele chegou a conseguir uma redução no preço da diária, mas estava convencido de que os proprietários ainda cobravam mais do que ele devia. A última discussão com os proprietários - quando ele resolveu se
} 
Para Van Gogh, uma parte importante da "vida real" que the foi privada diz respeito às mulheres e ao sexo. Ele comenta com o irmão que uma "boa mulher" dificilmente se sentiria tentada a visitá-lo em seu novo ateliê e que seria improvável que um caso passageiro resultasse em um relacionamento mais sério. Ele constata, por fim, que não poderia conciliar sua arte com uma "vida de farra".

De fato, [em Arles] os padrões morais me parecem menos desumanos e contrários à natureza do que em Paris. Mas, com meu temperamento, viver uma vida de farra e trabalhar não é de maneira alguma compatível e, nas atuais circunstâncias, será preciso contentar-se em fazer os quadros. Isso não é a felicidade e não é a vida real, mas o que fazer, mesmo esta vida artística que nós sabemos que não é a verdadeira, me parece tão viva, e seria ingrato da minha parte de não se contentar com ela. (Carta 602)

Ele volta a se lamentar por não conseguir se relacionar bem com as mulheres de Arles em uma carta posterior, na qual afirma que gostaria muito de pintar retratos das mulheres e das crianças da região, mas que não se sente suficientemente popular entre elas para isso. Ele se descreve como o oposto de um personagem do escritor Guy de Maupassant. No romance "Bel-ami", o personagem central, George Duroy, é muito popular com as mulheres de Paris, que Ihe dão o apelido de "bel-ami" (Carta 604).

Sem dispor de popularidade, Van Gogh não consegue convencer as mulheres a posar para seus retratos sem pagá-las. Isso é especialmente incômodo tendo em vista o quanto ele passa a dar importância para os retratos nessa época. "Hoje sou um pintor de paisagens, mas eu seria mais adequado para retratos" (Carta 626), diz em carta dirigida à irmã Willemien, de 20 de junho ${ }^{8}$.

mudar para o Café de la Gare, perto da casa amarela - foi parar no tribunal da cidade, que deu razão ao artista e fez o restaurante restituir o que Van Gogh tinha pago a mais. Provavelmente é esse tipo de "picuinha" a que Van Gogh se refere na carta e é possível que esses desentendimentos tenham contribuído para seu desconforto emocional.

${ }^{8}$ A valorização dos retratos, que o artista elege como o tipo de pintura mais nobre e mais verdadeiro, volta a aparecer em várias outras correspondências. Em carta a Theo de 31 de julho, ele afirma que a mudança que tentará promover em seus quadros é de pintar mais figuras. "É basicamente a única coisa que me emociona profundamente na pintura e que me faz sentir o infinito, mais do que o resto" (Carta 652). Ele menciona novamente os retratos em carta de 3 de agosto, em que diz a Theo que não há maneira melhor e mais rápida de melhorar o trabalho do que se dedicar à figura. "Além disso, eu sempre me sinto confiante quando faço os retratos, sabendo que esse trabalho é bem mais sério talvez essa não seja a palavra - mas são eles que me permitem cultivar o que tenho de melhor e mais sério" (Carta 654). 
Aparece, nesse período, um descontentamento generalizado em relação ao presente, ao mesmo tempo em que ele alimenta uma vaga esperança de que as coisas possam vir a melhorar. "Estou atualmente descontente comigo e descontente com o que eu faço, mas entrevejo a possibilidade de fazer melhor no futuro" (Carta 605).

A falta de dinheiro também é um motivo de queixa constante. "Isso me incomoda muito porque esse negócio me atrapalha consideravelmente o trabalho - e logo agora o tempo está muito bonito" (Carta 607).

Todo esse desconforto já descrito nas cartas anteriores é resumido em uma carta enviada a Theo no dia 20 de maio. Ali, aparece de forma mais clara do que nunca a ideia de que a arte exige do artista um pesado sacrifício de abdicação da vida real ("Existe, e permanece e sempre volta de tempos em tempos, no meio da vida artística, a nostalgia da - vida real - ideal e não atingível", Carta 611), que inclui a falta de mulheres, a perda da juventude e a perda da saúde.

Nós não sentimos que estamos morrendo, mas sentimos a realidade do fato de que não somos muita coisa e que, para estar em um elo da corrente de artistas, é preciso pagar um alto preço em saúde, juventude, liberdade, que nós não desfrutamos nem um pouco a mais do que o cavalo que puxa uma carruagem cheia de pessoas que vão para desfrutar a primavera. Enfim, eu desejo para você, como para mim mesmo, conseguir recuperar nossa saúde, porque nós precisamos dela. (Carta 611)

Aqui, Van Gogh faz longas considerações a partir de um diagnóstico que Theo recebera do médico Gruby. O diagnóstico não é especificado na carta (trata-se, provavelmente, de sífilis), mas Van Gogh menciona uma "letargia" experimentada por Theo. O artista comenta que Gruby provavelmente pedirá que Theo fique sem ver mulheres no período de convalescência. Em resposta a essa possível exigência, Van Gogh afirma que todas as mazelas sofridas pelos artistas são muito mais prejudiciais para a saúde do que o sexo.

Porque a solidão, as preocupações, as frustrações, a necessidade de amizade e de simpatia não totalmente satisfeita, eis o que há de muito ruim, as emoções morais de tristeza ou de decepções nos prejudicam mais do que a vida de farra, nós, eu digo, que somos os felizes proprietários de corações perturbados. (Carta 611) 
Mais uma vez, Van Gogh deixa claro o quanto sofre. Ao falar da doença do irmão, ele descreve, na verdade, suas próprias mazelas. O desabafo vem em um momento em que o desconforto parece ter atingido o ponto máximo, e em que o artista sente que não há muito o que fazer a respeito.

Nós não mais nos rebelamos contra as coisas, também não nos resignamos - estamos doentes e isso não vai melhorar - e não podemos fazer nada específico sobre isso. Eu não sei quem chamou esse estado de ser atingido ao mesmo tempo pela morte e pela imortalidade (Carta 611)

Nas cartas seguintes, depois de atingir plena consciência sobre seu mal-estar, Van Gogh volta a demonstrar lampejos de esperança, motivados principalmente pela possibilidade de Gauguin vir para o sul viver com ele na casa amarela.

\section{'Talvez Gauguin venha para o sul': nasce uma esperança (26/5 a 14/6)}

Foi ainda no início de maio que Van Gogh, pela primeira vez, mencionou a possibilidade de Gauguin vir morar com ele na casa amarela. Em março, Van Gogh recebera uma carta de Gauguin - que estava em Pont-Aven, na região da Bretanha em que o amigo lhe contava sobre dificuldades financeiras e sobre seu mau estado de saúde. Gauguin pedia que Van Gogh intercedesse junto a Theo para verificar se o marchand havia vendido algum de seus quadros. $\mathrm{O}$ artista imediatamente comunicou o irmão sobre o problema, e passou a procurar uma forma de ajudar o amigo ${ }^{9}$. Nas cartas seguintes, Van Gogh mostra-se comovido com o estado de penúria descrito por Gauguin e revolta-se contra a saúde ruim dos artistas de sua época. "O futuro ainda é difícil. Eu creio bem na vitória final, mas os artistas poderão desfrutar dela? Verão eles dias mais serenos?" (carta 583), questiona-se em carta de 9 de março.

A solução finalmente arquitetada por Van Gogh contemplava tanto os problemas de Gauguin como os dele próprio.

"Se necessário, eu poderia morar no novo estúdio com alguém, o que eu gostaria muito de fazer. Talvez Gauguin venha para o sul" (Carta 602). Foi desta forma,

\footnotetext{
${ }^{9}$ Em carta a Theo, Van Gogh assim descreve as penúrias do amigo Gauguin: "Recebi uma carta de Gauguin, que diz que ele tem estado doente, de cama há 15 dias. Que ele está sem dinheiro, já que teve que pagar algumas dívidas urgentes. Que ele gostaria de saber se você vendeu alguma coisa pra ele, mas que ele não poderia escrever para você temendo incomodá-lo. Que ele está sob tanta pressão para ganhar algum dinheiro que está decidido a reduzir o preço de suas pinturas ainda mais" (Carta 582).
} 
como um pensamento passageiro, que Van Gogh lançou a ideia que iria motivar muitas de suas oscilações emocionais posteriores.

O que parece uma ideia efêmera reaparece como uma proposta bem articulada, sobre a qual Van Gogh parece ter pensado muito intensamente. Em carta de 28 de maio, descreve a Theo seu plano de convidar formalmente Gauguin para vir para o sul. Esse convite envolvia diretamente Theo, já que era o irmão quem bancava a estadia de Van Gogh na Provença. O artista propõe que o irmão envie mensalmente uma quantia de 250 francos, que seria suficiente para sustentar os dois pintores na cidade, caso eles economizassem cozinhando em casa e dividindo os suprimentos.

"Você sabe que sempre me pareceu ridículo que os pintores vivessem sozinhos. Você sempre perde quando está isolado" (Carta 616), argumenta Van Gogh, em um esforço de tentar convencer o irmão sobre as vantagens do projeto.

A ideia da vinda de Gauguin desenvolve-se como uma novela, havendo momentos em que ela é tida como quase certa e, outros, em que o projeto esfria e aparenta estar longe de ser concretizado. A atitude ambígua de Gauguin - que em certos momentos acata o convite com entusiasmo e, em outros, age como se nem cogitasse de fato sair da Bretanha rumo ao Midi -, além da propensão de Van Gogh a construir "castelos no ar", contribuem para que a novela se prolongue cada vez mais.

Se, para o leitor das cartas, o vai e vem entre Van Gogh, Theo e Gauguin já se torna angustiante na medida em que a negociação se desenrola nesse triângulo, para Van Gogh, o processo todo o arrastou para um estado de esgotamento mental que chegou ao ponto máximo no fim de outubro, pouco antes da chegada de Gauguin.

Mas, neste primeiro momento, o tom geral com que o pintor trata da proposta é o de entusiasmo e de esperança de que dias melhores virão: "Este seria o começo de uma associação. Bernard, que vem para o sul também, se juntará a nós, e tenha certeza disso, ainda vejo você na França, à frente de uma associação de impressionistas" (Carta 616), escreve ao irmão.

Em carta de 27 de maio, ele diz que trabalha "com prazer" e deseja a Theo um domingo tão bom quanto o de Arles, que naquele dia tem "um sol esplêndido e nenhum vento" (Carta 614).

A devoção ao trabalho é enfatizada no seguinte trecho de carta enviada ao irmão em 29 de maio: "Eu tenho que desenhar muito, exatamente pela mesma razão 
que você falou na sua última carta - as coisas aqui têm tanto estilo. E eu quero chegar a um jeito mais deliberado e exagerado de desenhar" (Carta 617). No mesmo texto, aparecem sinais de esperança que seu trabalho vai evoluir e chegar ao ponto de ser vendido e apreciado pelo público: "Então eu digo para mim mesmo que podemos começar a esperar que, em pouco tempo, eu venderei um ou dois quadros por mês PORQUE AS COISAS VÃO MELHORAR" (Carta 617). O fato de Van Gogh ter escolhido escrever a afirmação com letras maiúsculas é significativo e pode indicar seu empenho em acreditar que as coisas realmente melhorariam.

No início de junho, Van Gogh vai a Saintes-Maries-de-la-Mer com o objetivo de explorar as paisagens da cidade litorânea. Ao irmão, ele descreve a cidade com detalhes, falando sobre a paisagem, as comidas, os eventos e as pessoas. "As pessoas não podem ser tão más aqui porque até o padre pareceu quase um sujeito decente" (Carta 619). É interessante observar a maneira como o artista descreve sua experiência estética na cidade, afirmando que uma caminhada na beira da praia não fora alegre nem foi triste, mas bonita.

Eu andei uma noite pela beira do mar na praia deserta. Não foi alegre, tampouco triste, foi - bonito. O céu, de um azul profundo, estava manchado de nuvens de um azul ainda mais profundo do que o azul primário, de um intenso cobalto, e de outras nuvens de um azul mais claro - como a brancura azulada das vias lácteas. No fundo azul, as estrelas brilhavam claras, esverdeadas, amarelas, brancas e rosa - mais claras, mais como as pedras preciosas do que em nossa casa - mesmo em Paris. É o caso de citar opalas, esmeraldas, lápis-lazúli, rubis e safiras. O mar de um azul ultramarino muito profundo - a praia de um tom avermelhado e de um púrpura pálido - com arbustos. Sobre a duna (de 5 metros de altura, a duna), os arbustos azuis-cobalto.

Com a viagem a Saintes-Maries-de-la-Mer, ele diz ter reconhecido a importância de estar no sul, "não tão longe da África", e o "equivalente do Japão", tão apreciado pelos impressionistas.

Ele está convencido de que uma longa permanência na região fará com que sua personalidade se desenvolva. A única ressalva que expressa em relação à situação que vive no sul é a de que estaria melhor se tivesse companhia. Para ele, os artistas deveriam trabalhar em grupo, de modo que um completasse o outro, e não criticasse o outro ao ponto de quase se anularem. 
Van Gogh menciona repetidas vezes estar curioso para saber que decisão Gauguin vai tomar: se aceitará a proposta de vir ao sul para morar com ele ou se permanecerá em Pont-Aven. Ele diz que, caso Gauguin aceite se juntar a ele, os dois se estabeleceriam como "exploradores do Midi" e que isso o faria avançar muito mais rapidamente na pintura. A esperança sobre a vinda do artista logo dá lugar à impaciência com a indecisão de Gauguin e ao descontentamento em relação ao trabalho e à vida.

\section{'Bastante mal-arranjado e triste' (15/6 a 7/9)}

Pela primeira vez desde que começou a negociação pela vinda de Gauguin, mencionada em boa parte das cartas escritas a partir do início de maio, Van Gogh afirma que talvez seja melhor não insistir mais pela vinda do colega, que deve ficar livre para aceitar ou não a proposta. A afirmação consta em carta enviada em 15 de junho para Theo (Carta 625). Van Gogh sente-se desconfortável em relação a um plano descrito por Gauguin de arrecadar 500 mil francos para estabelecer um mercado de pinturas impressionistas. Ele diz que Gauguin está exigindo muitas coisas com as quais os irmãos não podem se comprometer.

Quanto ao seu trabalho, Van Gogh expressa grande descontentamento por não produzir todos os dias.

Enfim - os dias em que eu concluo um estudo, eu digo a mim mesmo, se fosse assim todos os dias, a coisa poderia funcionar - mas os dias em que voltamos de mãos vazias, e comemos e dormimos e gastamos, no entanto, não ficamos satisfeitos com nós mesmos e nos sentimos como loucos, patifes ou velhos tolos. (Carta 625)

Ele volta a mencionar o sentimento de melancolia em carta enviada para a irmã Willemien entre 16 e 20 de junho. Depois de dizer que não ousa escrever a ela com tanta frequência quanto gostaria, nem incentivá-la a fazer o mesmo, justifica-se:

Toda essa correspondência nem sempre ajuda a nos manter, nós que somos de uma disposição nervosa, fortes em casos de possíveis imersões na melancolia do tipo a que você se refere em sua carta e que eu mesmo também tenho de vez em quando. Um amigo meu afirmou que o melhor tratamento para todos os males é tratá-los com o mais profundo desprezo. (Carta 626) 
Na mesma carta, demonstra uma desilusão com o mundo da pintura, em que tudo é comandado por interesses financeiros e em que as pessoas pagam mais por artistas mortos do que por artistas vivos. Além disso, fica triste por não poder enriquecer à medida que trabalha duro. O tema da perda da "vida real", em detrimento da arte, aparece mais uma vez: "Você vê o que eu encontrei, meu trabalho, e você também vê o que eu não encontrei, todo o restante que faz parte da vida". o descontentamento volta a aparecer no seguinte trecho: "Eu poderia facilmente me resignar a essa média e, por enquanto, o fato é que eu estou exatamente na mesma pilha de lixo de sempre".

Ao descrever para a irmã um autorretrato, caracteriza sua própria imagem na pintura como "bastante mal-arranjado e triste":

Aqui está uma impressão minha, que é o resultado de um retrato que eu pintei no espelho, que Theo tem: um rosto cor-de-rosa e cinza, com olhos verdes, cabelos cor de cinza, rugas na testa e em volta da boca, rigidez de madeira, uma barba muito vermelha, bastante mal-arranjado e triste. (Carta 626)

Os sinais de descontentamento em relação ao trabalho ("Estou bem insatisfeito com o que tenho feito nos dias de hoje, pois é muito feio", Carta 630) passam a vir acompanhados dos sinais de descontentamento em relação à própria cidade, em carta enviada a Theo em 23 de junho. As descrições da beleza, do clima propício, da natureza, das luzes e cores da região dão lugar a queixas quanto às pessoas de Arles. "A negligência e a imprudência preguiçosa das pessoas daqui é indescritível e nós somos prejudicados pelas menores coisas."

É como se ele estivesse se sentindo enganado em relação aos relatos que ouvira sobre a região: "Não consigo encontrar aqui a alegria meridional de que Daudet tanto fala, ao contrário, um encanto insípido, um descuido sórdido, o que não significa que a região não seja bonita" (Carta 630). Outra decepção se evidencia na seguinte frase: "Ao vir para cá, eu esperava que fosse possível criar amantes da arte aqui - mas até agora, eu não avancei um único centímetro para dentro do coração das pessoas" (Carta 636).

A esperança de chegar ao sucesso, ao ponto em que a venda de seus quadros compense todo o sacrifício e os gastos do irmão, se esvai: 
Entristece-me o fato de que a pintura seja como uma amante ruim, com a qual temos que gastar e gastar sempre, e nunca é suficiente, e de dizer a mim mesmo que, se por acaso, de tempos em tempos, haja um estudo passável, seria muito mais barato comprá-lo de outros. (Carta 630)

A época em que Gauguin finalmente diz ter aceitado a proposta de ir para o sul - o que é mencionado em uma carta de Van Gogh para Theo de 10 de julho - coincide com o período em que o pintor começa a mencionar repetidas vezes o cansaço que sente após longas sessões de trabalho.

Quando eu volto de uma sessão como essa eu posso lhe garantir que o meu cérebro está tão cansado que se esse tipo de trabalho for repetido com frequência - como está sendo feito durante a colheita - eu fico totalmente distraído e incapaz de fazer um monte de coisas comuns" (Carta 635).

A grande quantidade de trabalhos produzidos, principalmente desenhos, além da solidão na cidade e a esperança pela vinda de Gauguin são os elementos que caracterizam este momento. Em carta de 24 de julho, ele afirma que faria uma grande diferença se Gauguin estivesse lá porque há dias em que ele passa "sem dizer uma palavra a ninguém" e que viver no interior tem provocado o embrutecimento de seu caráter, processo que seria interrompido caso Gauguin viesse (Carta 648). "Agora você fala de um vazio que sente às vezes, essa é justamente a mesma coisa que eu também tenho" (Carta 650), diz a Theo.

Ele afirma se sentir esmagado pelas engrenagens das belas artes ("Neste momento, estou em minha pele e minha pele está na engrenagem das belas artes, como o grão entre as pedras de moer", Carta 656) e que, apesar de estar produzindo muitos desenhos e telas, tem a sensação de não estar fazendo absolutamente nada (Carta 657).

Quando Gauguin começa a adiar sua vinda ao sul, Van Gogh passa a considerar a possibilidade de se juntar a ele no norte, em Pont-Aven, jamais admitindo a possibilidade de permanecer sozinho em Arles: “Às vezes, parece provável, no entanto, que eu mesmo tenha que fazer a viagem, caso Gauguin não consiga se livrar da confusão em que está metido, se quisermos executar o plano" (Carta 657).

A falta de esperança em relação ao próprio sucesso como artista fica clara em dois trechos desta mesma carta. Primeiro, a constatação de que ele pode nunca 
recuperar o dinheiro que gasta para fazer seus quadros e se desenvolver enquanto artista: "É uma perspectiva bastante triste de ter de dizer que jamais, talvez, a pintura que eu faço adquira algum valor". Em seguida, a resignação em relação ao sucesso pessoal e à felicidade: "Se eu tivesse as mesmas ambições que ele [Gauguin], provavelmente não nos daríamos bem juntos. Mas eu não me importo com o meu sucesso ou com a minha felicidade, eu me importo com a continuação das empreitadas enérgicas dos impressionistas" (Carta 660). O tema da falta de esperança na vitória volta a aparecer em carta de 27 de agosto, a Theo:

Tenho um monte de ideias para o meu trabalho e, ao continuar trabalhando com afinco na figura, possivelmente encontraria algo de novo. Mas, o que quer você, eu me sinto muito fraco contra as circunstâncias dadas e precisaria ser mais sábio e mais rico e mais jovem para vencer. Felizmente para mim, eu não conto mais de forma alguma com uma vitória e, na pintura, não busco nada além do que um meio de levar a vida. (Carta 671)

No início de setembro, Van Gogh relata se deprimir com muita frequência (Carta 672). Mas o fato de Gauguin e outros artistas também se encontrarem na mesma situação parece servir de consolo: "(...) devemos, sobretudo, buscar o remédio dentro de nós mesmos, na boa vontade e na paciência". Ele acrescenta que sua vida está "agitada e inquieta" e que, talvez, mudar de casa com frequência só esteja piorando as coisas.

A indefinição de Gauguin sobre sua vinda volta a incomodar Van Gogh que, em carta enviada a Theo em 4 de setembro, diz que Gauguin "não dá a mínima", já que está adiando os planos há seis meses (Carta 674). Ele não quer insistir na vinda do amigo, já que teme que, uma vez no sul, Gauguin não goste da região e culpe os irmãos Van Gogh pela situação.

Mas uma esperança surge no horizonte. Depois de quase três meses marcados pela ansiedade sobre a vinda de Gauguin, pelas dúvidas em relação à mudança para a casa amarela, pelo esgotamento diante de uma intensa produção e pelo descontentamento e falta de esperança no sucesso da empreitada artística, Van Gogh passa a focar sua atenção em um único objetivo: transformar a casa amarela em uma verdadeira "casa de artista". As semanas que se seguem são de grande otimismo. 


\section{'Como as angústias não vêm sozinhas, as alegrias também não' (8/9 a 10/10)}

A carta que marca a transição foi enviada para Theo no dia 8 de setembro:

"(...) depois de algumas semanas de angústias, acabo de ter uma bem melhor. $\mathrm{E}$ assim como as angústias não vêm sozinhas, da mesma forma as alegrias também não" (Carta 676).

Ele conta que, diante do fato de ter gasto muito mais dinheiro do que o justo na pensão onde se hospedou por último, o Café de la Gare, resolveu propor ao dono de pintar o ambiente boêmio do café como forma de recuperar seu dinheiro. Para Van Gogh, a estratégia é uma forma de lidar com o problema "de uma forma alegre". Este é o quadro "The night café" que, no fim das contas, o artista resolve não vender ao proprietário por considerar "uma das pinturas mais feias" que já fez. Apesar disso, a partir da descrição da pintura, Van Gogh promove uma de suas explicações mais interessantes sobre o modo como deliberadamente usa as cores para evocar emoções ("Tentei exprimir com o vermelho e o verde as terríveis paixões humanas", Carta 676). Este material será levado em conta posteriormente neste trabalho, como referência para a análise das pinturas selecionadas.

Van Gogh mostra-se animado com o fato de Theo ter enviado dinheiro para que ele pudesse mobiliar a casa amarela e finalmente se mudar para o local. Para ele, o fato de ter uma casa iria aliviar a melancolia que sente por "estar na rua":

Mas, Gauguin vindo ou não, se eu comprar os móveis, então teremos, em um bom ou mau ambiente - esta é outra questão - um pied-à-terre, um lar que retire do espírito essa melancolia de estar na rua. Isso não é nada quando você é um aventureiro de 20 anos, mas é ruim quando já passou dos 35. (Carta 676)

A partir deste momento, os preparativos da casa amarela começam a determinar um estado de otimismo intenso.

Boa parte de seus esforços são destinados a criar o que ele chama de uma verdadeira "casa de artista", onde ele possa viver com serenidade e receber seus colegas artistas, constituindo uma tão sonhada comunidade artística.

"Isso não é nem um pouco urgente, mas eu tenho a minha ideia. Eu realmente quero transformá-la em uma casa de artista, mas não preciosa, pelo contrário, nada de precioso, mas tudo desde a cadeira até a mesa deve ter personalidade" (Carta 677). 
As palavras sublinhadas são provavelmente uma referência ao livro "La Maison d'un Artiste", na qual o escritor Edmond de Goncourt faz uma descrição detalhada de sua casa no boulevard Montmorency, onde todas as obras de arte são citadas como em um guia de museu. Van Gogh havia citado o autor em uma carta anterior.

Para criar esse refúgio, ele compra duas camas, duas esteiras, tecidos para fazer lençóis, cadeiras, espelho e outras "pequenas coisas indispensáveis". É curioso observar que ele relata ter comprado 12 cadeiras. Para alguém que, a princípio, viverá sozinho, parece uma quantidade exagerada de assentos. Mas, como bem observado pelos editores das cartas, o número pode ser uma referência aos apóstolos, já que ele acreditava que os artistas deveriam viver juntos como monges. Ou ainda à Irmandade Pré-Rafaelita, sobre a qual Van Gogh pensava erroneamente ser composta de 12 membros.

Van Gogh toma a decoração da casa como uma das tarefas mais nobres que já assumiu para si: "Eu não saberia exprimir o quanto me dá prazer ter encontrado um trabalho grande e sério. Porque esta será, assim eu espero, uma verdadeira decoração que eu espero empreender", Carta 677. Neste momento, Van Gogh diz que não tem nenhuma dúvida sobre os benefícios de permanecer em Arles e que lá as "ideias vêm em abundância para o trabalho". Ele inclusive encomenda mais tintas, pois prevê um outono maravilhoso.

Em carta à irmã Willemien, enviada entre 9 e 14 de setembro, ele volta a descrever com prazer seu trabalho de decoração casa amarela e diz esperar que ela possa visitá-lo no ano seguinte. $\mathrm{O}$ artista começa a fazer planos de longo prazo para seu novo lar. "Lá dentro [da casa], eu posso viver e respirar e refletir e pintar" (Carta 678), diz Van Gogh, acrescentando que o calor do sul está fazendo com que seu sangue circule normalmente, diferentemente do que estava ocorrendo em Paris.

A necessidade de pintar a alegria e outros sentimentos positivos aparece no seguinte trecho, da mesma carta: "Minha querida irmã, eu creio que atualmente é preciso pintar os aspectos ricos e magníficos da natureza, nós precisamos de alegria e de felicidade, de esperança e de amor" (Carta 678).

Depois de um período em que a indefinição sobre a vinda de Gauguin causara tanto desconforto e ansiedade, é contrastante a forma como ele se expressa sobre o assunto em carta de 10 de setembro para Theo. Quando Gauguin insinuou que seria 
preciso que Theo pagasse também sua jornada para o sul, além da ajuda financeira que o marchand já havia garantido caso o artista fosse se juntar ao irmão em Arles, Van Gogh deixou claro ao irmão que achava injusta tal proposta. Mas recomendou que encarassem essa questão com serenidade. Logo ele, que parecia estar sempre alternando a melancolia com a exaltação, neste momento mostra sinais de raro equilíbrio mental e capacidade de ver as situações de um ponto de vista mais neutro, sem tanto envolvimento emocional.

"É melhor ter serenidade do que ser muito temeroso. Por que então fazer tanto barulho por causa desse caso com Gauguin. Se ele vier para junto de nós, ele fará bem e nós queremos deixá-lo vir. Mas nem ele, nem nós devemos ficar devastados" (Carta 679). Van Gogh ainda ocupa boa parte de sua correspondência com o irmão discutindo o caso de Gauguin, mas dá a entender que a questão não o incomoda mais a ponto de afetar seu trabalho. "As ideias para o trabalho me vêm em abundância e isso faz com que, mesmo estando isolado, eu não tenha tempo de pensar ou de sentir. Eu ando como uma locomotiva de pintar" (Carta 680).

Para ele, o fato de ter um endereço fixo faz com que um artista possa trabalhar com mais calma: "Eu sempre volto a repetir que, uma vez fixados em um único local, trabalhamos mais tranquilamente" (Carta 680). A ideia volta a aparecer na carta seguinte: "Quanto ao trabalho, eu já me sinto mais livre e menos atormentado pelas preocupações desnecessárias do que antes" (Carta 681).

A mudança oficial para a casa é mais um motivo de contentamento: "Esta noite, eu dormi na casa e, apesar de ainda haver coisas a serem feitas, eu me senti muito feliz. Além do mais, sinto que posso fazer algo que vai durar e do qual outros também poderão se beneficiar" (Carta 682).

As descrições entusiasmadas das cores e da natureza arlesiana voltam a tomar conta de suas cartas, em oposição ao período anterior, em que se tornara crítico da cidade e de seus moradores:

Por eu nunca ter tido uma sorte tamanha, aqui a natureza é extraordinariamente bonita. Tudo está em todos os lugares. A abóboda do céu é de um azul admirável, o sol tem uma radiação de um enxofre pálido, que é doce e charmoso como a combinação dos azuis celestes e dos amarelos de Vermeer de Delft. Eu não poderia pintar tão bonito 
quanto isso, mas isso me absorve tanto que eu me deixo ir sem pensar em nenhuma regra. (Carta 683)

Nesta mesma carta, ele relata, bem humorado, que até conseguiu reunir um "público seleto" enquanto pintava, composto de "quatro ou cinco alcoviteiros e uma dúzia de meninos que acharam especialmente interessante ver a cor saindo dos tubos".

Seu desejo é de dividir a alegria com o irmão: "Eu estou tão feliz com a casa com o trabalho - que eu ouso acreditar que as alegrias não ficarão sozinhas, mas que você irá compartilhá-las de seu lado também" (Carta 683).

Aparece neste mesmo texto a ideia da negação da decadência: "Que dias estes, não por causa dos eventos, mas eu sinto fortemente que tanto eu quanto você não somos a decadência, nem estamos acabados e nem estaremos no futuro" (Carta 683). Em carta posterior, escrita em 3 de outubro, a questão da negação da decadência volta a aparecer: "Se eu recuperar meu dinheiro já gasto, e que você me emprestou ao longo dos anos, nós expandiremos a coisa e buscaremos fundar um ateliê de renascença, e não de decadência" (Carta 694).

Em meio à onda de otimismo, há algumas cartas no final de setembro em que Van Gogh expressa o medo de se sentir solitário caso não receba companhia na casa amarela. O temor parece vir associado ao mau tempo e à lembrança de que o inverno está chegando. Em carta de 23 de outubro, para Theo, o artista lamenta que o bom tempo dos últimos dias tenha desaparecido, substituído por lama e chuva. E observa que ele tem de aproveitar, caso o bom tempo volte antes do inverno, "pois os dias ensolarados são curtos" (Carta 686).

"Acredito que acabarei não me sentindo mais sozinho na casa e que, em dias de mau tempo de inverno, por exemplo, e de noites longas eu encontrarei uma ocupação que me absorverá completamente" (Carta 686).

Quando o bom tempo outonal volta a ser sentido em Arles, Van Gogh volta a se entusiasmar com a paisagem ("Pelo tempo em que durar o outono, não terei mãos, telas e cores suficientes para pintar tudo o que eu vejo de belo", Carta 687), mas o medo de como enfrentará o inverno ronda o artista como um fantasma. 
Tenho uma lucidez terrível nos momentos em que a natureza está tão bela nestes dias e então eu não me sinto mais e a pintura vem para mim como em um sonho. Tenho realmente um pouco de receio, porém, que isso terá sua reação de melancolia quando nós estivermos na estação ruim, mas vou tentar escapar disso ao estudar essa questão de desenhar retratos de memória. (Carta 687)

O medo de vir a sentir solidão futuramente volta a aparecer na seguinte passagem: "A solidão não me incomoda provisoriamente e, mais tarde, encontraremos alguma companhia e talvez até mais do que queremos" (Carta 689). Para Nagera, trata-se de um apelo ao recurso da negação, ao qual Van Gogh recorre com frequência (NAGERA, 1980, p. 114)

Apesar das menções a uma possível solidão futura, as cartas do período continuam cheias de referências à beleza da região, à tranquilidade de ter uma casa e aos planos para o futuro promissor de sua arte. A "esperança" aparece como uma entidade com vontade própria em duas cartas escritas em 3 de outubro: uma enviada ao irmão e outra a Gauguin:

Eu sempre senti vagamente que, neste inverno, nós colocamos nosso próprio coração em discussões com tantas pessoas interessantes e artistas, mas eu ainda não ousava esperar. Depois do esforço contínuo de sua parte e da minha até agora, começa a aparecer no horizonte: a Esperança. (Carta 694)

É dessa forma - com inicial em letra maiúscula, como um nome próprio - que Van Gogh se refere à esperança em carta a Theo. O artista profetiza que, apoiando Gauguin e os outros artistas, Theo será o primeiro "marchand-apóstolo".

Quanto a mim, eu vejo um futuro para a minha pintura e igualmente um trabalho entre os artistas. Porque se você buscará nos fornecer dinheiro, eu empurrarei todos os que vierem à minha porta a produzir e serei um exemplo eu mesmo. Ora, tudo isso, se tivermos boa vontade, será para formar uma coisa mais durável do que nós mesmos. (Carta 694)

Em carta a Gauguin, a menção à esperança aparece da seguinte forma: "No presente, em uma onda do horizonte, eis que ela vem a mim, a esperança, essa esperança fugidia que em minha vida solitária por vezes me consolou" (Carta 695). 
A proximidade da vinda de Gauguin intensifica a onda de otimismo: "Como estou feliz por Gauguin, eu não vou procurar expressões para lhe dizer, então - vamos ter coragem e bom ânimo!" (Carta 697).

A sensação de calma é citada ainda em uma última carta, antes de a inquietude e o cansaço voltarem a tomar conta de seu discurso. "Mas vamos em frente, e eu me sinto muito calmo mesmo com todos esses terremotos que estamos vivenciando" (Carta 700). A calma aparece como ingrediente essencial para o sucesso da empreitada artística: "Temos que recuperar o dinheiro gasto durante todos esses anos improdutivos. Com calma, nós faremos tudo isso. É, de qualquer modo, nosso direito e nós sofremos muitas vezes por esse motivo" (Carta 700).

Mas, em breve, Van Gogh começa a demonstrar os efeitos dos "terremotos" que enfrentou, em forma de cansaço e esgotamento.

\section{'Devastado moralmente e esgotado fisicamente' (10/10 a 28/10)}

Quando Gauguin mais uma vez avisa que vai adiar sua ida ao sul porque está doente e teme sofrer durante a viagem, o frágil equilíbrio experimentado por Van Gogh nas últimas semanas começa a se desfazer. Em carta de 10 de outubro, em que avisa Theo sobre o novo adiamento, ele demonstra impaciência sobre a hesitação de Gauguin (a ele, enviou a seguinte observação: "Se não estiver muito doente, venha imediatamente, por favor. Se você estiver muito doente, envie telegrama e carta, por favor"). Além disso, o evento desencadeia nova onda de inquietação e culpa pelos gastos que impõe ao irmão. De repente, ele começa a se arrepender de ter gastado tanto com a mobília da casa amarela.

"Quando ultimamente penso com muita frequência que todas as despesas da pintura pesam sobre você, então você não pode imaginar como tenho me sentido inquieto" (Carta 702). A inquietação aparece novamente no seguinte trecho da mesma carta: "Se eu não estivesse terrivelmente, e sempre, perturbado por essa inquietação, diria que as coisas estão funcionando porque o trabalho vai melhorar e a saúde está muito melhor do que em Paris" (Carta 702).

Em carta de 17 de outubro, Van Gogh menciona certa melancolia por não produzir nada de forma independente: 
Enfim, meu querido irmão, veja, se você se queixa de não ter nada na cabeça, no sentido de ser capaz de produzir coisas boas, então veja que eu tenho muito mais razão de sentir também uma melancolia como essa. Eu não faria absolutamente nada sem você, mas não vamos nos preocupar com o que produzimos dessa maneira, juntos. Vamos fumar nossos cachimbos em paz, sem nos atormentar até o ponto da melancolia por não produzir separadamente e com menos dor. (Carta 707)

Menções ao cansaço e ao esgotamento físico e mental começam a permear os relatos de Van Gogh nesses dias de outubro. Diz que sente a "cabeça vazia" ou que fica "atordoado" depois de um período de trabalho duro. Em carta de 21 de outubro, prevê que ficará doente se não parar de pintar por alguns dias:

Não estou doente, mas ficarei sem a menor dúvida se não comer uma comida nutritiva e se não parar de pintar por alguns dias. Estou novamente quase reduzido ao estado de loucura de Hugo van der Goes na pintura de Emile Wauters. E se não fosse pelo fato de que eu tenho algo como uma natureza dupla, algo de monge e algo de pintor, eu estaria completamente, e desde há muito tempo, reduzido ao estado mencionado acima. (carta 709)

A tão esperada chegada de Gauguin a Arles, anunciada por Van Gogh em carta enviada ao irmão em 25 de outubro, não parece ser suficiente para interromper o processo de esgotamento que entrou em curso nas semanas anteriores. Van Gogh diz ter esperança de que, ao lado de Gauguin, produzirá mais e que a chegada do amigo o ajudou a se sentir melhor, em um momento em que teve a sensação de que ficaria doente. Apesar das manifestações positivas em relação à nova companhia, Van Gogh ocupa boa parte de sua carta lamentando sobre os gastos que impõe ao irmão.

Eu me sinto, ao ponto de estar devastado moralmente e esgotado fisicamente, a necessidade de produzir, justamente porque eu não tenho nenhum, nenhum outro meio de jamais recuperar nossas despesas. Não posso fazer nada se minhas telas não vendem. O dia virá em que as pessoas verão que elas valem mais do que o preço da tinta e da minha subsistência, muito escassa inclusive, que investimos nelas. Não tenho outro desejo nem outra preocupação em relação a dinheiro ou a finanças a não ser, em primeiro lugar, não ter dívidas. Mas, meu caro irmão, minha dívida é tão grande que, quando eu tiver pagado, o que eu acho que conseguirei fazer, as dificuldades de produzir pinturas terão, no entanto, tomado minha vida inteira, e parecerá a mim que eu não vivi. (Carta 712) 
Em carta de 27 de outubro, Van Gogh já menciona uma melhora em seu estado de espírito e de saúde, apesar de o cansaço ainda prevalecer: "Eu sinto ainda meu cérebro cansado e seco, mas eu me sinto melhor esta semana do que na quinzena anterior" (Carta714).

\section{'Somos felizes juntos' (29/10 a 11/12)}

Depois das repetidas queixas sobre cansaço e esgotamento, Van Gogh tranquiliza o irmão em carta de 29 de outubro. Nela, ele explica que o cansaço foi resultado do esforço excessivo empregado nas negociações sobre a vinda de Gauguin e nos preparos da casa amarela para receber o amigo. Van Gogh também ameniza as reclamações sobre os gastos, afirmando que, com a chegada de Gauguin, seria possível economizar e até guardar algum dinheiro.

A partir de novembro, as cartas são escritas com menos frequência, o que impede uma avaliação mais precisa sobre as oscilações emocionais do pintor. Se, em outubro, Van Gogh enviou 20 cartas, em novembro foram apenas sete. Nelas, ele deixa transparecer sua admiração por Gauguin e sua esperança de que a presença dele estimule seu trabalho.

"Nós trabalhamos muito e a vida a dois funciona muito bem" (Carta 717), escreve Van Gogh ao irmão em carta de 3 de novembro. O artista menciona que o amigo tem estimulado que ele pinte quadros de cabeça, o que tem aumentado sua produtividade nos dias de tempo ruim: "Faz um tempo de vento e de chuva aqui e estou muito contente por não estar sozinho. Eu trabalho de cabeça nos dias de tempo ruim, o que não daria certo se estivesse sozinho" (Carta 718).

À irmã Willemien, em carta de 12 de novembro, conta com otimismo a novidade sobre a mudança de Gauguin para o sul. "Mas eu me lembro de ainda não Ihe ter contado que meu amigo Paul Gauguin, pintor impressionista, vive agora comigo e que nós somos muito felizes juntos, ele me incentiva muito a trabalhar frequentemente de pura imaginação" (Carta 720).

Trata-se de um breve período de melhora, ou de aparente melhora, em meio à crise que enfrentava. A presença de Gauguin, no entanto, também faz com que ele passe a ver em seu trabalho indícios de imaturidade, o que traz muita frustração. "Atualmente, estou em plena merda, os estudos, os estudos, os estudos e isso ainda 
prosseguirá - uma desordem tal que lamento, portanto, que isso me fará estar pronto [como artista] aos 40 anos" (Carta 723).

Em dezembro, ele chega a mencionar a Theo que Gauguin está apresentando dificuldades para se adaptar, mas não dá em nenhuma medida a dimensão do problema que os dois estão enfrentando na convivência.

Creio que Gauguin esteja um pouco desanimado com a boa cidade de Arles, com a pequena casa amarela onde trabalhamos e, sobretudo comigo. Na verdade há ainda, tanto para ele quanto para mim, dificuldades graves para superar aqui. Mas essas dificuldades estão mais em nós mesmos do que em outros lugares. (Carta 724)

Na última carta que escreve no ano de 1888, em 18 de dezembro, Van Gogh relata uma melhora no relacionamento com Gauguin, que passa a se sentir melhor em Arles e volta atrás em sua decisão de mudar-se para Paris. Mas a tranquilidade é temporária. Na noite de 23 de dezembro, toda a instabilidade emocional de Van Gogh culmina no episódio em que, depois de uma discussão com Gauguin, ele corta fora um pedaço de sua própria orelha e a entrega a uma prostituta chamada Rachel.

A próxima carta que Van Gogh escreverá, já em janeiro, será do hospital de Arles, o Hôtel Dieu, ao lado do médico Félix Rey.

A partir da leitura das cartas de Van Gogh, foi possível observar em seu discurso as características a ele atribuídas por vários pesquisadores que se debruçaram sobre a vida do artista. A instabilidade emocional que marcou sua estadia em Arles foi apenas uma intensificação do padrão de comportamento que já fazia parte de sua trajetória desde a adolescência.

A disposição para a melancolia e para as oscilações emocionais bruscas começaram a aparecer de forma nítida na vida de Van Gogh, segundo Sweetman, a partir do episódio em que ele deixou a escola aos 15 anos de idade, por motivos que não foram bem documentados. Durante 15 meses, após esse episódio, sua vida sofreu uma paralisação completa. "Mais tarde, haveria períodos de inatividade parecidos, mas nestes estava claro que estava sofrendo de um distúrbio mental que ocasionava 
momentos de obsessão maníaca seguidos de um mergulho desesperado numa melancolia profunda." (SWEETMAN, 1993, p. 25)

Já na fase adulta, experimentou uma dessas oscilações quando trabalhava na filial da galeria Goupil na Inglaterra, depois de uma suposta rejeição por parte de Eugénie Loyer, filha da proprietária da casa onde alugava um quarto em Londres. "Para Vincent, isso era o fim de tudo. A passagem da euforia para o silêncio e a tristeza foi doentiamente brusca. Continuou a ir para o trabalho, mas a muito custo conseguia manter um interesse mínimo pelo que estava se passando." (SWEETMAN, 1993, p. 49)

No período de Arles, as "contradições" no comportamento de Van Gogh não passaram despercebidas por Gauguin, que as tomou como sinais de um acirrado conflito interior:

\begin{abstract}
Anos depois, Gauguin lembrou a violência e a rapidez com que Vincent podia mudar de personalidade: de 'brusco e impetuoso em excesso' para ameaçadoramente silencioso, e vice-versa. Num minuto, ele expunha de modo irrefutável as razões pelas quais Gauguin devia ficar em Arles e afetuosamente traçava planos para uma exposição conjunta; no minuto seguinte, ficava colérico e acusava o hóspede de maquinar maldades e, depois que Gauguin se recolhia ao quarto, ficava andando de cá para lá, como se receasse uma fuga noturna. (NAIFEH e SMITH, 2012, p. 810)
\end{abstract}

Nagera (1980, p. 113) também destaca as oscilações de Vincent durante o período em que viveu Arles: “Às vezes, se queixa de seu nervosismo e ansiedade. Está, em alguns momentos, animado e, em outros, deprimido. Seu isolamento e sua solidão não contribuem para aliviá-lo".

Naifeh e Smith (2012, p. 129) afirmam ainda que os hábitos de solidão e de melancolia em Van Gogh vinham desde a infância. A melancolia é citada pelos autores como um dos temas que o perseguiram ao longo da vida - ao lado do amor, da saudade e do sentimento de pertença - em seu alheamento cada vez maior. Para Theo, Van Gogh estava "frequentemente no limiar da melancolia" e, desde suas primeiras crises, começou a mergulhar na espiral de sua instabilidade mental.

(...) as pessoas percebiam que ele ficava ou ausente e perdido em seus pensamentos, ou começava de repente a falar e a rir alto demais. Ele próprio sabia disso e, em carta a Theo, comentou que as pessoas não deviam se importar de ser consideradas excêntricas. (SWEETMAN, 1993, p. 75) 
Em um trecho de carta escrita pelo pai de Vincent citado por Johanna van Gogh-Bonger (2008, p. 50), o pastor Theodorus van Gogh destaca a característica do filho de renegar a felicidade e escolher os caminhos mais difíceis na vida: "Uma coisa que nos entristece muito é perceber que ele literalmente não conhece as alegrias da vida, sempre caminha com a cabeça baixa, mesmo que nós tenhamos feito tudo que estava a nosso alcance para que ele obtivesse uma situação honrada!".

Levando em conta que essas características são frequentemente mencionadas pelas pessoas que conviviam com Vincent, e que elas também aparecem com destaque nas biografias e outras obras acadêmicas sobre o artista, é válido questionar se elas não tiveram um papel importante no desenvolvimento de sua obra.

A partir deste momento, tendo delimitado os períodos de oscilação emocional que Vincent sofreu em Arles, torna-se possível selecionar obras cujas análises e comparações sejam capazes de responder aos seguintes questionamentos:

De que forma essas oscilações emocionais interferiram em sua produção artística? Pinturas produzidas em momentos de melancolia têm características que as diferem das obras criadas em momentos de euforia ou de serenidade? É esta a próxima etapa deste trabalho.

\subsection{Análise dos quadros}

Para avaliar o possível impacto das oscilações de Van Gogh em sua produção artística, busquei temas que tivessem aparecido de forma recorrente ao longo do período da vida do artista abordado por este trabalho. Desta forma, torna-se possível analisar a forma como Van Gogh escolheu retratar o mesmo tema sob a influência de diferentes estados de espírito.

Para chegar a esse tema comum, várias possibilidades foram consideradas. Alguns dos temas recorrentes pintados nesta época foram os girassóis (ele pintou quatro telas com o tema entre fevereiro e dezembro de 1888), os autorretratos (foram cinco pintados em Arles), os pomares em flor (foram 11 telas com o tema na primavera de 1888), as naturezas-mortas, os campos de trigo, entre outros. 
Porém, a produção de cada um desses temas tende a se concentrar em determinada época do ano, não sendo possível, desta forma, analisá-los sob os diferentes estados emocionais do artista. Os quatro girassóis, por exemplo, foram pintados no final de agosto, para a decoração da casa amarela (posteriormente, em 1889 , ele voltaria ao tema). Os pomares floridos foram pintados, naturalmente, entre o final de março e o final de abril, início da primavera. A produção das naturezasmortas concentra-se nas semanas iniciais em Arles, quando o tempo ainda estava muito frio para que Van Gogh pudesse sair em busca de temas ao ar livre. Os retratos começam a aparecer a partir de julho, quando Van Gogh começou a ter modelos à disposição. Antes disso, ele não conhecia as pessoas da cidade bem o suficiente para convencê-las a posar para ele.

O único tema por mim identificado - entre os mais de 200 quadros produzidos em Arles - que reaparece periodicamente ao longo da estadia de Vincent na cidade é o do pôr do sol. Ele recorreu ao tema em março, junho, julho outubro e novembro. Certa vez, Vincent escreveu que os raios de um pôr do sol eram capazes de expressar "o ardor de um ser vivo" (Carta 673) por isso esta parece ser uma escolha adequada. As obras selecionadas para esta análise são, portanto:

"Pollard willows with setting sun" (F 572 / JH 1597) ${ }^{10}$, que data da primeira quinzena de março; "Sower with setting sun" (F422 / JH 1470) e "Wheatfield with setting sun" (F 465 / JH 1473), que datam da segunda quinzena de junho; "Sunset at Montmajour" (F - / JH - ), que data da primeira semana de julho; "Sand barges" (F 437 / JH 1570) e "Sand barges" (F 438 / JH 1571), que datam da primeira semana de outubro; "Red vineyard" (F 495 / JH 1626), que data da primeira semana de novembro e "Sower with setting sun" (F 450 / JH 1627), que data da segunda quinzena de novembro.

Desta forma, "Pollard willows with setting sun" foi produzida em meio à crise de melancolia que abateu sobre Vincent nas primeiras semanas em Arles. "Sower with setting sun", "Wheatfield with setting sun" e "Sunset at Montmajour" foram pintadas em meio a uma nova crise, em que o pintor relata se deprimir com frequência e se

\footnotetext{
${ }^{10}$ As letras "F" e "JH" referem-se, respectivamente, às classificações propostas pelo catalogue raisonné do pesquisador Jacob Baart de la Faille, publicado em 1970, e o do pesquisador Jan Hulsker, publicado em 1996.
} 
mostra desiludido com a arte e decepcionado pela hesitação de Gauguin em ir ao sul. Já os dois quadros com o título de "Sand barges" são do período de empolgação e euforia, com os preparos da casa amarela para receber Gauguin. Os últimos dois pores do sol do período, "Red Vineyard" e o segundo "Sower with setting Sun", foram pintados na fase em que Vincent relata "viver feliz" com Gauguin em Arles. Esta é a fase, porém, em que o artista escreve menos cartas, o que faz com que seja mais difícil determinar exatamente seu estado de espírito no período.

Cabe ressaltar que a descoberta da obra "Sunset at Montmajour" ${ }^{11}$ foi anunciada pelo Museu Van Gogh em 9 de setembro de 2013. Se já é uma raridade que uma nova pintura seja atribuída à obra de Van Gogh nos dias de hoje, o fato de ela se enquadrar exatamente nos critérios propostos por este trabalho - sendo um quadro de pôr do sol pintado no período de Arles - foi constatado com grande surpresa. A obra, portanto, foi incluída nesta análise posteriormente.

\footnotetext{
${ }^{11}$ De acordo com reportagem do jornal britânico "The Guardian", o quadro recém-atribuído a Van Gogh havia passado anos esquecido em um sótão na Noruega. Segundo os pesquisadores do Museu Van Gogh, o quadro foi adquirido por um industrial norueguês chamado Christian Nicolai Mustad em 1908, sob a orientação do historiador da arte Jens Thiis. Segundo relata a família, um embaixador francês na Suécia visitou Mustad e, ao ver a obra, sugeriu que se tratava de uma falsificação ou uma atribuição errônea. Diante da observação, Mustad baniu a pintura ao sótão. Recentemente, depois de uma reavaliação da pintura, o Museu Van Gogh constatou a autenticidade do quadro e identificou, inclusive, referências a ele na correspondência de Van Gogh.
} 
Pollard willows with setting Sun (F 572 / JH 1597)

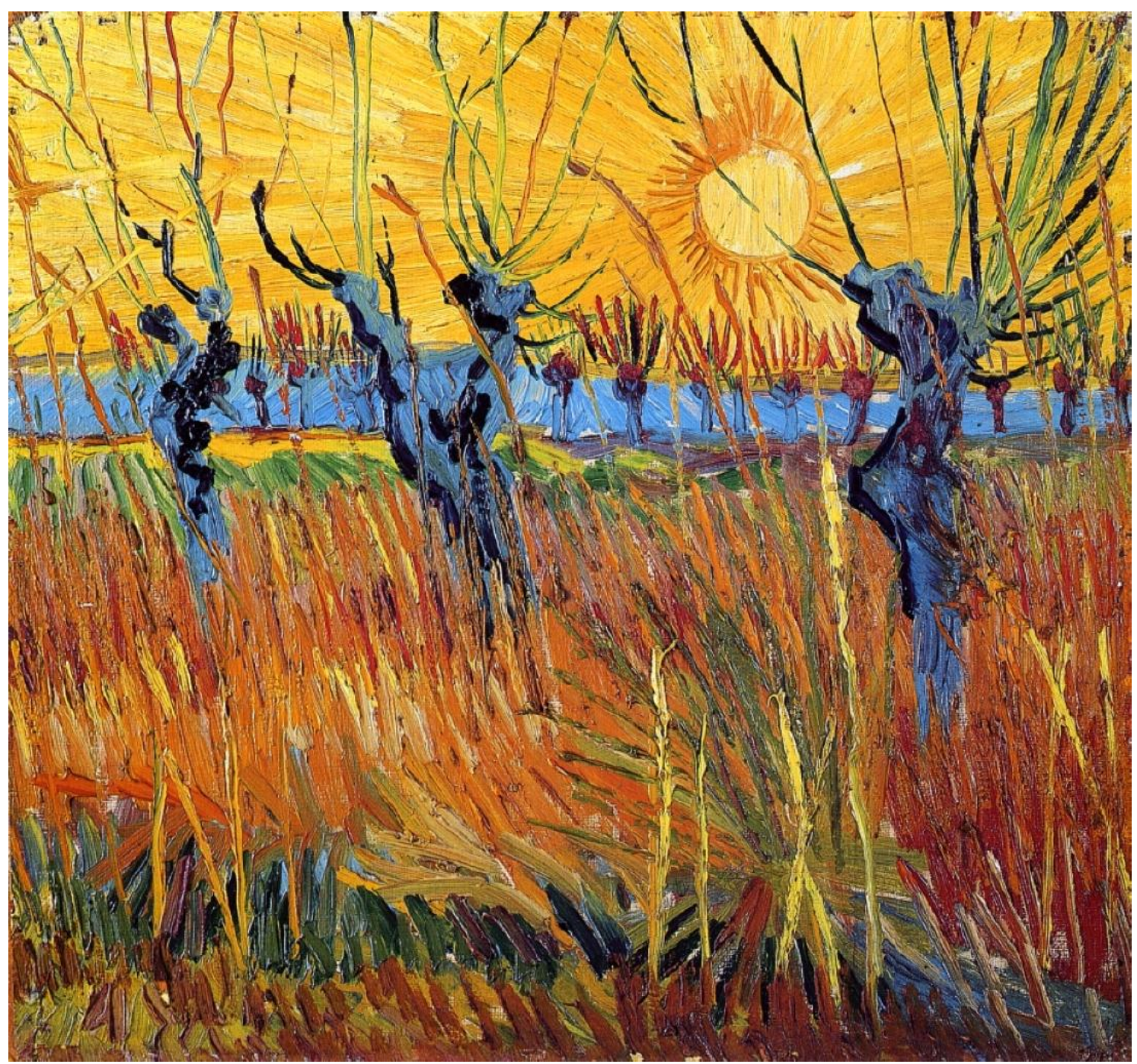

Figura 1 - Pollard willows with setting sun (F 572 / JH 1597), março de 1888, óleo sobre tela - 31,6 x 34,3 cm. Kröller-Müller Museum, Otterlo, Holanda

O primeiro pôr do sol feito em Arles retrata três salgueiros em primeiro plano. São salgueiros decotados (pollard willows), ou seja, podados de tal forma que, a partir dos nós onde são feitos os cortes, nasçam numerosos brotos finos e longos. O artista já havia pintado salgueiros decotados em outras ocasiões. Como Van Gogh não escreveu detalhes ou impressões sobre esta pintura específica nas cartas do período, recorri a outros momentos em que o tema aparece em sua correspondência com o objetivo de entender se existia alguma ligação afetiva especial do artista em relação ao assunto.

Os salgueiros decotados aparecem pela primeira vez em suas cartas quando Van Gogh atuava como missionário na região mineira do Borinage, na Bélgica, em 
dezembro de 1878. Ele cita a espécie como a árvore típica da Holanda, ao fazer uma comparação com a paisagem vegetal do Borinage: "Assim como no Brabant nós temos os bosquetes e a madeira de carvalho, e na Holanda temos os salgueiros decotados, aqui vemos os espinheiros-negros espalhados pelos jardins, campos e terras." (Carta 149).

Van Gogh volta a citar esse tipo de salgueiro como a árvore símbolo da paisagem holandesa em duas cartas posteriores, escritas em abril e em novembro de 1889. Nas duas ocasiões, ele compara o salgueiro holandês com as oliveiras do sul da França.

É como os salgueiros podados de nossos prados holandeses ou os arbustos de carvalho de nossas dunas, quer dizer, o murmúrio de um olival tem algo de muito íntimo, imensamente antigo sobre ele. É bonito demais para eu ousar pintá-lo ou conseguir formar uma ideia sobre ele. (Carta 763)

A oliveira é variável como nosso salgueiro decotado no norte. Você sabe que os salgueiros são muito pitorescos, apesar de parecerem monótonos, são a árvore típica do país. Agora o que o salgueiro é em nosso país nativo, a oliveira e o cipreste têm exatamente a mesma importância aqui. (Carta 823)

Uma observação reveladora, em que Van Gogh usa o salgueiro decotado como exemplo, aparece em carta escrita a Theo entre 12 e 15 de outubro de 1881, época em que o artista vivia com os pais em Etten. Aqui, fica claro que Vincent quer infundir deliberadamente, em suas pinturas, emoções humanas em objetos inanimados. Essa característica seria, posteriormente, destacada por muitos dos pesquisadores que analisaram sua obra:

Eu sinto cada vez mais, conforme o tempo passa, que o desenho de figuras em particular é bom, e que também promove, indiretamente, uma melhora no desenho de paisagens. Se alguém desenha um salgueiro decotado como se fosse um ser vivo, o que na verdade é, então os arredores seguem mais ou menos naturalmente, se a pessoa foca toda sua atenção naquela única árvore e não descansa até que exista vida nela. (Carta 175)

O sentimento que Vincent atribui a um salgueiro decotado, em uma carta posterior, é justamente o da melancolia: 
Lá, eu vi um salgueiro decotado morto, o tipo de coisa para Barye ${ }^{12}$, por exemplo. Ele pairava sobre um lago com juncos, sozinho e melancólico, e sua casca era desgastada e coberta por musgos, e pontilhada como o mármore de vários tons - algo como a pele de uma cobra, esverdeada, amarelada, principalmente preta. Com manchas brancas de descamação e galhos atarracados. (Carta 251)

A carta foi escrita para Theo em 26 de julho de 1882, enquanto vivia em Haia. $\mathrm{Na}$ carta seguinte, escrita em 31 de julho, ele conta para o irmão que pintou a paisagem sombria do salgueiro na beira da estrada de ferro. E o imaginou como um homem, como o funcionário encarregado da sinalização da linha de trem. "Em suma, eu queria fazê-lo do modo como eu imagino que o sinaleiro, com seu uniforme e bandeira vermelha, vê e sente quando pensa 'como está sombrio hoje'" (Carta 252).

Ao retomar as referências que Vincent faz aos salgueiros ao longo de sua correspondência, concluímos que, além de apreciar o valor estético ${ }^{13}$ das árvores com podas tão peculiares, Vincent também tem uma ligação emocional importante com o tema. Primeiramente, ele considera a árvore como o símbolo de sua Holanda nativa, evocando-a em vários momentos como um parâmetro de comparação em relação às espécies das paisagens francesas.

Não é de se surpreender que, ao chegar a uma região desconhecida e distante da família e dos amigos, Vincent procure um tema que remeta às suas origens. Posteriormente, Vincent passaria a discutir com o irmão sobre a importância de retomar as amizades da Holanda, como um retorno às raízes. A escolha dos salgueiros decotados como tema para uma de suas telas parece anteceder essa tendência. Em meio à crise de melancolia que recaiu sobre o pintor nas primeiras semanas em Arles, deve ter sido com prazer que ele descobriu na paisagem do Midi os saudosos salgueiros que remetiam à sua terra natal.

Um segundo ponto a ser observado sobre a relação de Vincent com os salgueiros é o fato de ele atribuir emoções humanas à árvore, em especial a solidão e a melancolia. Talvez o formato esguio e seco da árvore contribua para que Vincent veja nela uma figura humana. É especialmente interessante o fato de ele comparar a árvore

\footnotetext{
${ }^{12}$ Antoine-Louis Barye (1796 - 1875) foi um escultor francês.

${ }^{13}$ Em carta escrita em outubro de 1881 a Anthon van Rappard, ele declara que os velhos salgueiros decotados que margeiam e estrada até a estação de Etten estão "absolutamente bonitos".
} 
a um homem: o sinaleiro à beira da estrada de ferro, que sente a atmosfera sombria da paisagem.

Existe ainda outro momento da correspondência em que Van Gogh cita os salgueiros de forma a personificá-los. O trecho aparece em uma carta a Theo escrita em março de 1883, quando o artista vivia em Haia: "Por um longo tempo, eu fiquei ali olhando, em frente a uma fileira dos salgueiros decotados mais nodosos, retorcidos e desorientados que eu já vi".

Se, para Van Gogh, os salgueiros são solitários, melancólicos, desorientados, atentos à paisagem sombria ao seu redor e ainda remetem à Holanda nativa, é possível imaginar que, ao pintar uma dessas árvores, ele estivesse projetando nela suas próprias emoções. O salgueiro pode ser visto como o próprio artista, à medida que os sentimentos que atribui à árvore também aparecem atribuídos a ele próprio em outros momentos da correspondência.

Quanto às cores da tela, predominam o amarelo e o laranja, que aparecem tanto no céu ensolarado quanto na vegetação ao redor dos salgueiros. As árvores têm troncos azuis e os galhos finos que nascem a partir da poda são verdes. Uma faixa azul separa essa vegetação da linha do horizonte. As cores são vibrantes, exatamente como Van Gogh esperava da paisagem do sul. "(...) hoje em dia, as pessoas estão exigindo contrastes de cor e cores muito intensas e variadas nas pinturas, em vez de um cinza moderado" (Carta 579), escreve Vincent a Willemien ao justificar sua ida para o sul da França.

Quero começar dizendo a você que esta parte do mundo me parece tão bonita quanto o Japão pela clareza da atmosfera e os efeitos de cores alegres. As águas fazem manchas de um belo esmeralda e um rico azul nas paisagens, como você vê nas estampas japonesas. Pores do sol de um laranja pálido fazem os campos parecerem azuis - esplêndidos sóis amarelos. (Carta 587)

Nesta carta enviada a Theo em 18 de março, pouco tempo depois de ter pintado o quadro dos salgueiros e já citada anteriormente neste trabalho, Vincent justifica o uso do azul nos campos e nos troncos: trata-se do efeito da luz do pôr do sol sobre a paisagem. As pinceladas - verticais para a vegetação e horizontais para o céu do pôr do sol - têm aspecto vigoroso e selvagem. Elas representam bem a ausência de um sistema formal de pintura como o pregado pelos impressionistas. 
Dou toques irregulares do pincel na tela, que deixo como saem. Trechos de cor em camadas grossas, locais da tela a descoberto, aqui e ali partes que ficam absolutamente inacabadas, repetições, selvagerias; em suma, estou propenso a achar que o resultado é tão inquietante e perturbador que pode ser uma dádiva dos céus para aqueles que têm ideias preconcebidas sobre a técnica. (NAIFEH e SMITH, 2012, p. 666)

Apesar de podermos relacionar os salgueiros decotados com os sentimentos de solidão e melancolia ao recordar a relação de Vincent com esse tema, o efeito da obra no espectador é a de uma paisagem vigorosa e selvagem, talvez um pouco árida, mas com cores intensas e alegres. Esse contraste é observado por Sweetman:

Ao olhar esses trabalhos ensolarados, felizes, o observador fica com a impressão de que há dois Vincent, pois, embora ele estivesse lutando para recomeçar do zero em Arles, todos os seus velhos problemas continuavam a atormentá-lo. Nessas pinturas radiantes, não vemos nada do sofrimento do homem que as pintou. Ele estava se sentindo extremamente só. Raramente se permitia admitir isso e se esforçava muito para fingir o contrário. (SWEETMAN, 1993, p. 210)

A análise desta primeira tela de pôr do sol mostra, portanto, que existe um contraste entre o sentimento experimentado pelo artista e o efeito da tela sobre o espectador.

Existe ainda outro momento na vida de Vincent em que ele escolhe os salgueiros decotados como tema. É em dezembro de 1882, em uma ilustração em que as árvores servem de pano de fundo para um semeador. O semeador é justamente o tema da próxima tela a ser analisada. 


\section{Sower with setting sun (F422 / JH 1470)}

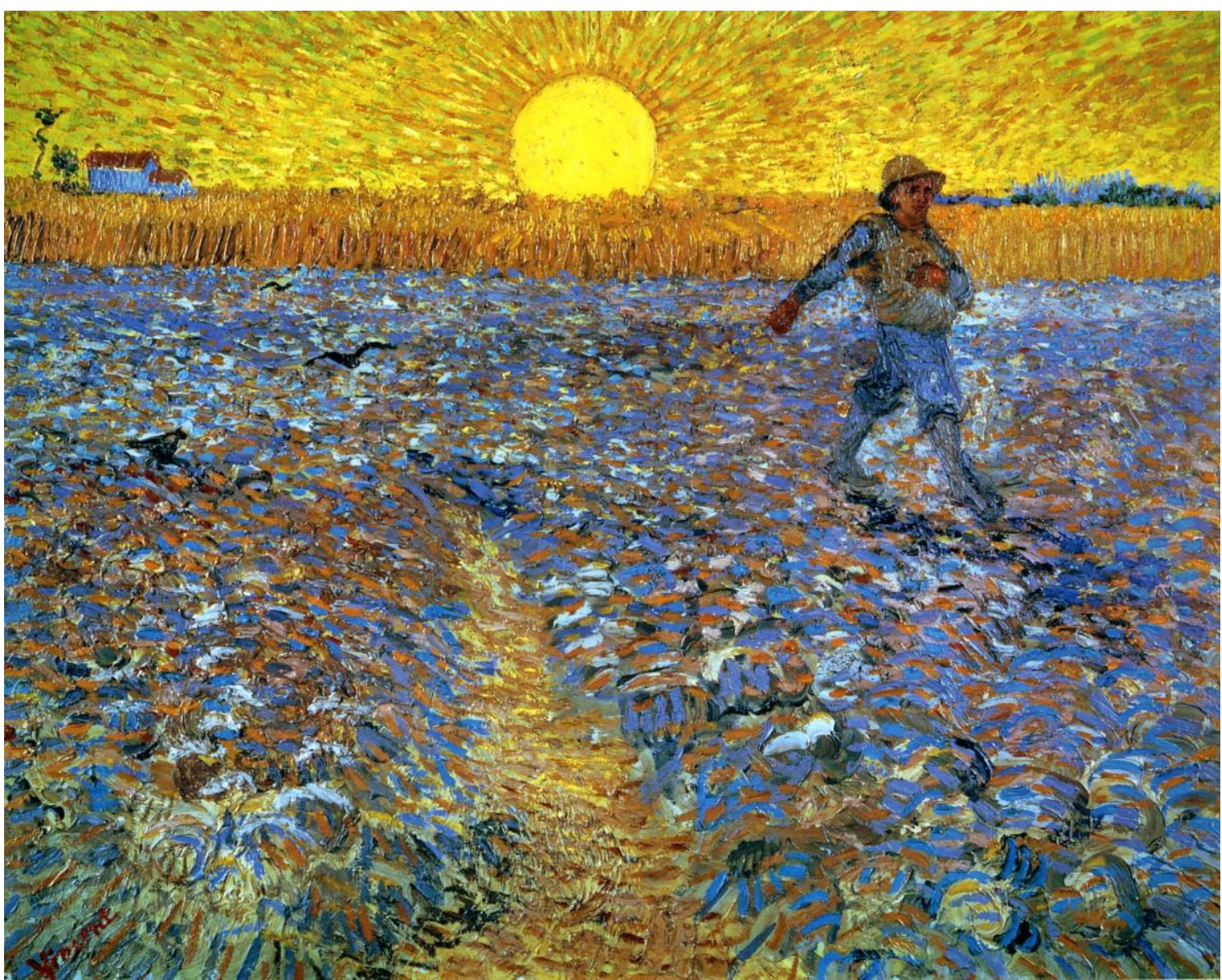

Figura 2 - Sower with setting sun (F422 / JH 1470), junho de 1888, óleo sobre tela - 64,2 x 80,3 cm. Kröller-Müller Museum, Otterlo, Holanda

Se Vincent não mencionou em suas cartas a pintura dos salgueiros, o semeador foi descrito à exaustão enquanto era produzido. Entre 17 e 21 de junho, o artista anunciou que estava trabalhando no tema em cartas aos amigos John Peter Russel e Emile Bernard e ao irmão Theo. Esboços da paisagem foram enviados aos dois amigos. A relação de Vincent com o tema do semeador vinha de longa data.

Por tanto tempo, tem sido meu grande desejo fazer um semeador, mas os desejos que eu tenho há muito tempo nem sempre são realizados. Eu, então, quase tenho medo dele. Ainda assim, depois de Millet e Lhermitte, o que me resta fazer é... o semeador, com cores e em grande formato. (Carta 629)

Naifeh e Smith (2012, p. 714) afirmam que, "preso em um vórtice de ruminações sombrias" como estava Van Gogh, o semeador foi para ele como um 
consolo, uma imagem reconfortante a que se apegou no momento em que, após a morte do tio Cent $^{14}$, passou a refletir sobre a possibilidade de existirem mundos "invisíveis". Desconsolado pela falta de reconhecimento ao trabalho dos artistas, ele ficava imaginando "se poderia existir 'um outro hemisfério' da vida onde os artistas fossem reconhecidos por si mesmos e não por sua venda, onde se retirasse o peso da culpa e se perdoassem os erros do passado".

Para ele, o semeador era símbolo do infinito: "Eu não escondo que não detesto o campo - tendo sido criado lá, os sopros de memórias antigas, as aspirações pelo infinito, das quais o Semeador e o feixe de cereal são os símbolos, ainda me encantam como antigamente" (Carta 628).

Mas, para Van Gogh, não foi fácil entregar-se ao tema quando suas expectativas em relação aos resultados eram tão altas. Ele menciona estar trabalhando no quadro pela primeira vez em 17 de junho. No dia 28 , ele conta que voltou a trabalhar na pintura, que está completamente "reformulada". Para Van Gogh, que costumava concluir uma tela em uma única tarde, essa atitude diante de uma obra é uma exceção.

Ele tinha dois semeadores em quem se inspirar. Um era a pintura "O semeador", de Millet, que Van Gogh havia copiado insistentemente a partir de reproduções em seus primeiros anos como artista. A outra era a ilustração de mesmo nome feita por Augustin Lhermitte, que Van Gogh conhecia de uma reprodução publicada em "Le Monde Illustré", que ele havia mencionado em uma carta anterior. Ele teve de confiar na lembrança dessas figuras e em sua própria imaginação para criar a figura do semeador, pois em junho, quando pintou o quadro, era época da colheita, e não da semeadura.

A imagem da figura altaneira, andando a passos largos, com a sacola de
sementes ao ombro e o braço estendido, o perseguia desde as
profundezas do Borinage, como portadora de uma mensagem de

\footnotetext{
${ }^{14} \mathrm{O}$ tio, também chamado Vincent Willem van Gogh, irmão do pai de Vincent, havia introduzido Vincent e Theo no mundo do comércio das artes. Cent, que era sócio da rede de galerias de arte Goupil, ficou muito decepcionado quando Vincent passou a negligenciar suas funções na filial de Paris, o que levou o jovem a ser demitido do trabalho. Todo o comportamento inadequado do sobrinho depois disso, incluindo o fato de ele ter vivido com a prostituta Sien, em Haia, também foi motivo de desaprovação por parte do tio. Em seu testamento, tio Cent declarou expressamente que tinha a intenção que Vincent não recebesse nada de seu espólio. Theo, pelo contrário, foi beneficiado e, inclusive, usou parte do dinheiro da herança para financiar a ida de Gauguin para Arles.
} 
esperança. Nos anos seguintes - em Etten, em Haia, em Drente, em Nuenen -, tentara inúmeras vezes expressar a promessa de redenção pela perseverança, que seu pai pregara, a que Millet dera forma e que todos os heróis de sua imaginação, de Eliot a Zola, confirmavam. Mas falhara em todas as tentativas. (NAIFEH e SMITH, 2012, p. 714)

O tratamento que Vincent dá às cores do semeador salta aos olhos. Na tela, o sol é de um amarelo vivo, enquanto o campo é representado em azul. Trata-se de uma inversão: na realidade, o céu seria azul e os campos, amarelos. Walther (2012, p. 48) observa que, apesar de as cores escolhidas pelo artista diferirem das cores reais da paisagem, um quadro como esse não é de forma alguma abstrato: ele conserva a realidade concreta, mas usa a cor como meio de expressão do pintor.

Nisso está a verdadeira expressividade de Van Gogh. Ele mostra um recorte da realidade e ao mesmo tempo a sua interpretação, por meio da cor e da composição. E só esta interpretação, em contraste com a manifestação concreta, revela a veemência da sua vontade expressiva, o gesto pictural enérgico. Uma segunda realidade, estética, puramente subjetiva, sobrepõe-se à primeira. (WALTHER, 2012, p. 48)

É dessa forma que ele próprio descreve as cores da pintura, em carta de 21 de junho a Theo: "Sobre um campo arado, um grande campo de torrões de terra violeta subindo até o horizonte -, um semeador em azul e branco. No horizonte, um campo de trigo maduro curto. Sobre tudo isso, um céu amarelo sobre um sol amarelo" (Carta 629). Depois dessa descrição, Van Gogh acrescenta que "a cor desempenha nessa composição um papel muito importante". Em uma carta anterior, enviada a Emile Bernard em 19 de junho, Van Gogh já tinha dito que não se importava se as cores do quadro não correspondiam às cores da realidade:

Há muitas repetições de amarelo na terra, tons neutros, resultado da mistura entre violeta e amarelo, mas eu quase não dou a mínima para a veracidade da cor. Melhor fazer imagens ingênuas de almanaque - do velho almanaque onde o granizo, a neve, a chuva e o tempo bom são representados de um modo bastante primitivo. (Carta 628)

Ainda sobre as cores do "Semeador", na mesma carta enviada a Emile Bernard, Van Gogh aproveita para falar sobre o significado do branco e do preto. Em cartas anteriores, ele havia proposto um questionamento sobre o tema ao amigo: afinal, por que não se podia usar o branco e o preto puros nas pinturas? Mas, neste caso 
específico, ele deveria estar se referindo a uma versão a anterior da tela, pois menciona que a calça do semeador é branca. No quadro que chegou até nós, a calça do semeador é azul, em um tom um pouco mais intenso do que o campo de trigo:

Eis o que eu queria falar sobre o branco e o preto. Vamos pegar o Semeador. A tela é dividida em dois, uma metade é amarela, a parte de cima, e a parte de baixo é violeta. E a calça branca descansa o olho e o distrai, no momento em que o contraste simultâneo excessivo de amarelo e de violeta se tornaria irritante. É isso o que eu queria dizer. (Carta 628)

A expectativa alta de Van Gogh em relação à tela e ao significado do semeador em sua vida, somada ao fato de que ele a pintou em um momento difícil, em que predominavam a melancolia e a insatisfação sobre seu trabalho, fez com que Naifeh e Smith descrevessem o quadro como um "campo de batalha":

Vincent avançava a e recuava da imagem angustiante numa luta tão tensa e renhida quanto a luta paralela com Gauguin e Theo sobre o futuro da Casa Amarela. A tela que era o campo de batalha registrou todos os impulsos e todas as derrocadas da confiança (NAIFEH e SMITH, 2012, p. 714)

Para os autores, Van Gogh imaginou pintar seu semeador "tal como Delacroix pintara Cristo no mar da Galileia: um símbolo de calma em meio à tempestade, da serenidade na adversidade, da reencarnação por meio do sofrimento". No momento em que Vincent sofria, a figura que espalhava sementes do renascer foi uma tentativa de obter alento.

“Mas a imagem ainda não o satisfazia. Descartou o resultado de toda essa dedicação ao trabalho como mero 'estudo exagerado' - mais uma semente que não germinara" (NAIFEH e SMITH, 2012, p. 716). 
Wheatfield with setting sun (F 465 / JH 1473)

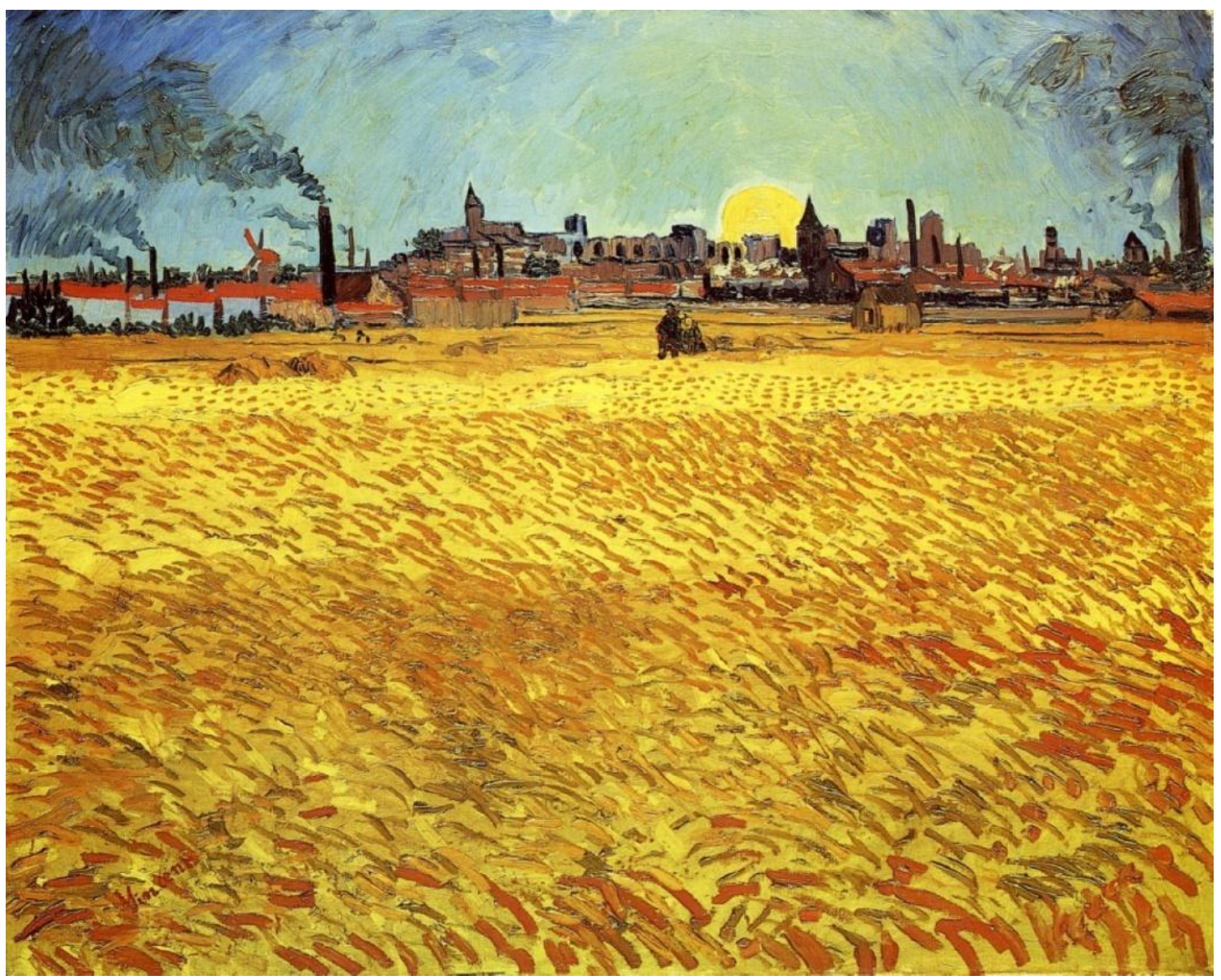

Figura 3 - Wheatfield with setting sun (F 465 / JH 1473), junho de 1888, óleo sobre tela - 74 x $91 \mathrm{~cm}$, Kunstmuseum Winterthur, Winterthur, Suíça

Produzido quase simultaneamente ao "Semeador", o "Campo de trigo com pôr do sol" trabalha com as cores de modo mais previsível do que o quadro anterior. Aqui, o campo de trigo é dourado e o céu de fim de tarde é azul: exatamente o oposto do que ocorre no "Semeador". O próprio Van Gogh descreve a pintura da seguinte forma, em carta ao amigo Emile Bernard:

Aqui está outra paisagem. Pôr do sol? Nascer da lua? Noite de verão, em todo caso. Cidade violeta, astro amarelo, céu azul verde, os trigos têm todos os tons: ouro velho, cobre, ouro verde, ouro vermelho, ouro amarelo, bronze amarelo, verde, vermelho. Tela número 30 quadrada. Eu a pintei em pleno mistral. Meu cavalete estava fixado na terra com estacas de ferro, método que eu recomendo. (Carta 628)

Esse trecho é ambíguo no que diz respeito ao "astro amarelo" representado na tela. Afinal, trata-se do sol ou da lua cheia? Para os especialistas do Museu Van Gogh, 
parece não haver dúvida de que se trata do sol poente, já que o nome oficial do quadro foi determinado "Campo de trigo com pôr do sol". Mas a ambiguidade é destacada na descrição do quadro feita pelo Kunstmuseum Winterthur, na Suíça, onde a pintura se encontra atualmente.

Se no "Semeador" a presença da cidade parece ser sugerida apenas por uma mancha azul no canto direito superior da tela, no "Campo de trigo" a proximidade de Arles fica em evidência. Há chaminés com fumaça, moinhos de vento e torres de igreja no horizonte do quadro. Em vez do semeador, há um casal solitário que caminha entre o campo e a cidade. $\mathrm{O}$ azul radiante do céu forma um arco sobre a esfera amarela do sol poente. O forte vento mistral faz com que o trigo e a fumaça das chaminés se inclinem para a esquerda.

O tema parece ter sido significativo para Van Gogh, já que ele escolheu pintá-lo em um formato grande (a tela mede $74 \mathrm{~cm}$ por $91 \mathrm{~cm}$; em comparação, a tela do semeador mede $64,2 \mathrm{~cm}$ por $80,3 \mathrm{~cm}$ ). Em outra carta a Emile Bernard, Vincent volta a falar sobre os campos de trigo. Nesta época, Van Gogh se dedicou a uma série de pinturas sobre o tema:

É que cansa, este sol daqui. Eu sou completamente incapaz de julgar meu próprio trabalho. Eu não posso ver se os estudos são bons ou ruins. Tenho sete estudos de trigo, infelizmente, contra a minha vontade, são apenas paisagens. Paisagens de ouro velho amarelo, feitas rápido, rápido, rápido e apressadas como o ceifador que fica em silêncio sob o sol escaldante, concentrando-se em ceifar. (Carta 633)

A frustração por pintar "apenas paisagens" provavelmente se deve ao fato de que sua ambição mais profunda era de pintar retratos, que ele valorizava como o tipo mais nobre de pintura.

Mais uma vez, apesar das descrições de frustração, cansaço e desconforto feitas por Vincent na época em que pintava essa tela, o efeito da pintura é luminoso. Apesar do céu mais sombrio de início de noite, o dourado do trigo, que ocupa dois terços da tela, confere uma sensação quente e reconfortante ao espectador.

Para Van Gogh, o trigo tem o poder simbólico de acalmar quem o observa. Em carta escrita em 2 de julho de 1889 para a irmã Willemien, depois de perguntar se ela já lera a tragédia "Rei Lear", de William Shakespeare, Vincent afirma: “Mas, enfim, eu acho que não vou insistir muito que você leia livros tão dramáticos, já que eu mesmo, 
depois dessas leituras, sou obrigado a ir olhar uma folha de erva, um galho de pinheiro, uma espiga de trigo, para me acalmar" (Carta 785).

Em carta escrita ao irmão Theo neste mesmo dia, ao falar sobre o sofrimento da mãe diante da partida do filho mais novo, Cor, Vincent recomenda a contemplação de um campo de trigo como remédio a ser tomado quando a dor adquire "as proporções desesperadoras de um dilúvio": "Disso, nós sabemos muito pouco, de proporções, e é melhor olhar para um campo de trigo, mesmo no estado de pintura" (Carta 784).

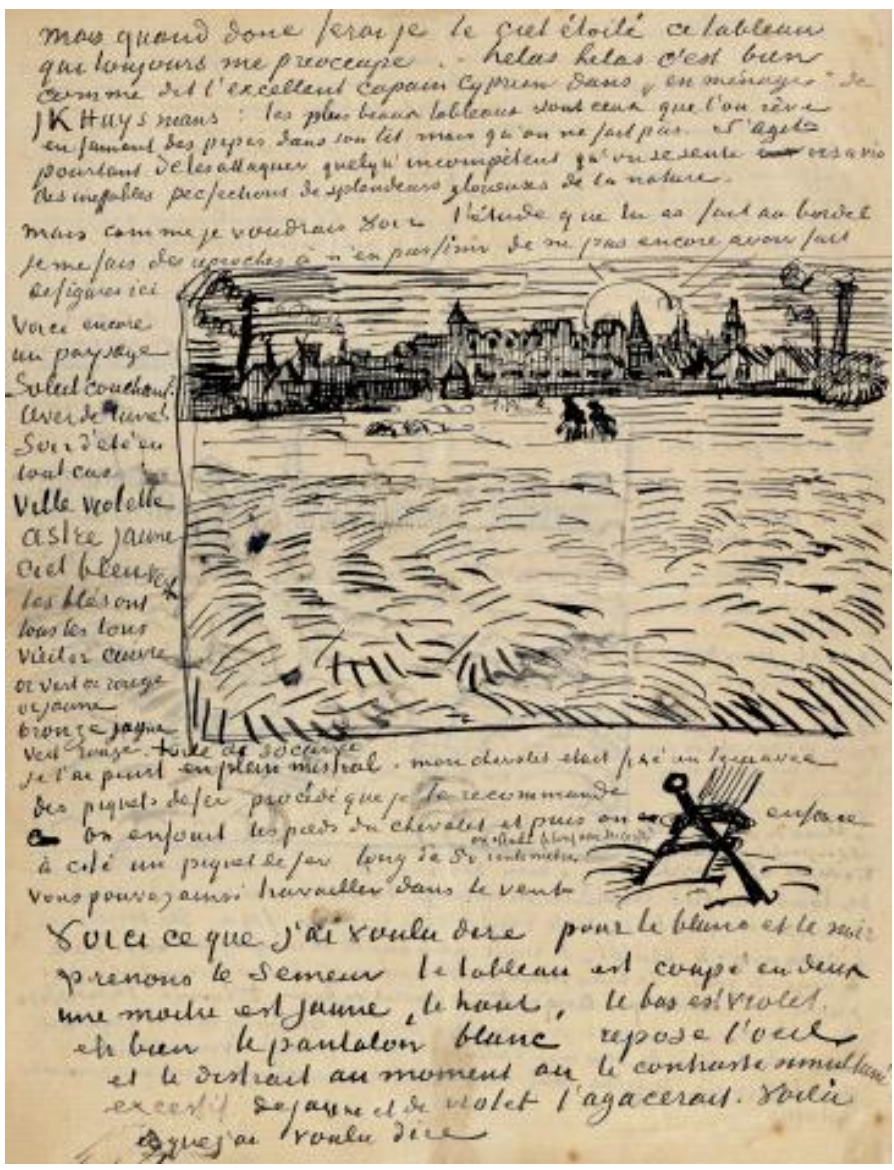

Figura 4 - Fac-símile da Carta 628, escrita em 19 de junho para Emile Bernard, onde Van Gogh desenhou um esboço do quadro Wheatfield with setting 
Sunset at Montmajour ( F - / JH - )

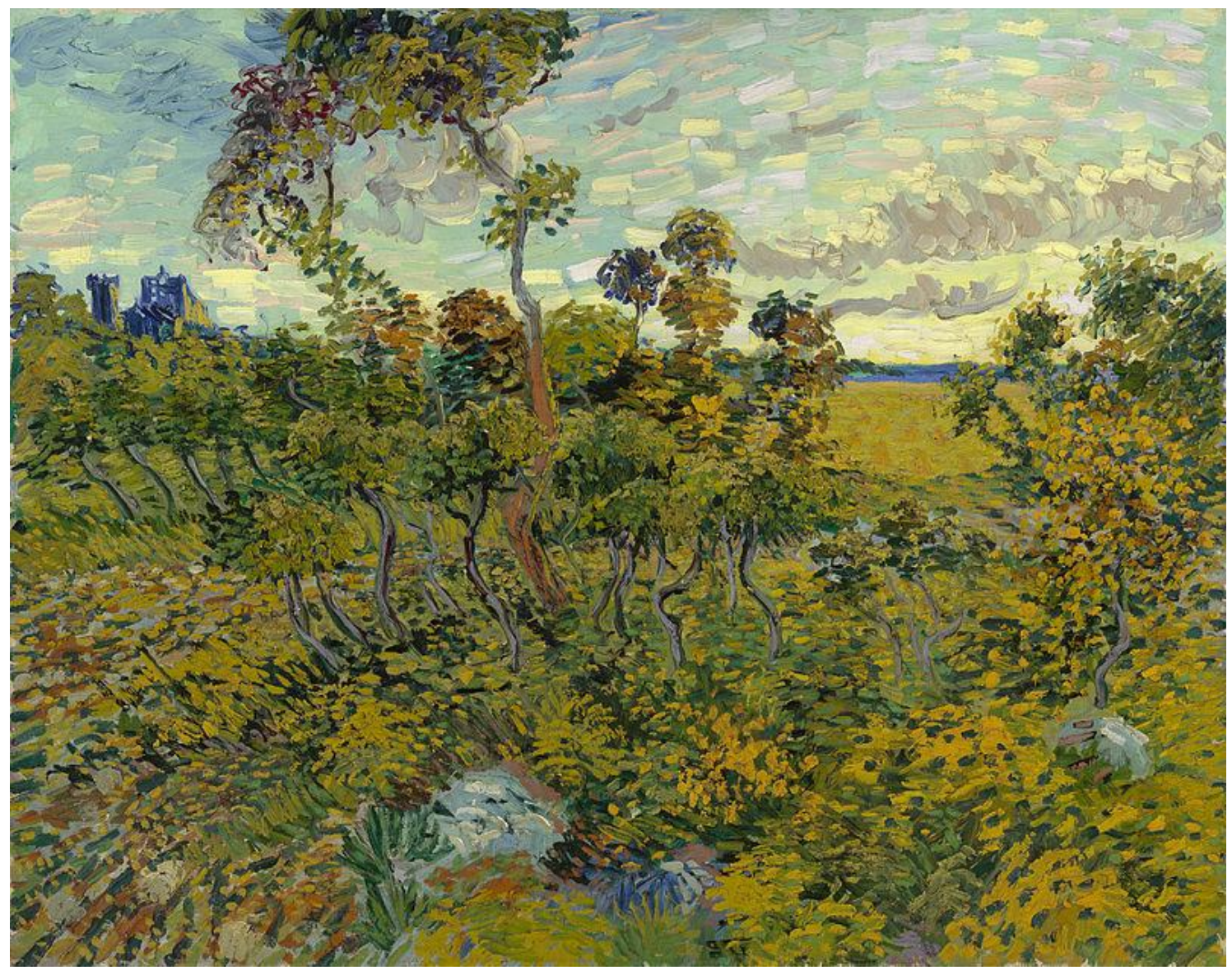

Figura 5 - Sunset at Montmajour (F - / JH -), julho de 1888, óleo sobre tela - 93,3 x 73,3 cm. Coleção privada

Ontem, no pôr do sol, eu estava em uma charneca pedregosa onde crescem carvalhos muito pequenos e retorcidos, no fundo, uma ruína sobre a colina e um campo de trigo no vale. Foi romântico, não poderia ter sido mais, à la Monticelli, o sol lançava raios muito amarelos sobre os arbustos e sobre a terra, absolutamente uma chuva de ouro. E todas as linhas eram belas, tudo tinha uma nobreza encantadora. Não ficaria nem um pouco surpreso de ver surgir repentinamente cavalheiros e damas retornando de uma caça com falcões ou de ouvir a voz de um velho trovador provençal. A terra parecia violeta, à distância, azul. Eu voltei com um estudo de lá, mas ele está bem abaixo do que eu queria fazer. (Carta 636)

Foi desta forma que Vincent descreveu a tela "Pôr do sol em Montmajour", em carta enviada a Theo de 5 de julho de 1888. Mas foi apenas em 2013 que a obra foi reconhecida como um trabalho autêntico de Van Gogh.

No dia 9 de setembro de 2013, o Museu Van Gogh anunciou com grande destaque a descoberta de um novo quadro de Van Gogh. O anúncio repercutiu na imprensa do mundo todo. Para a minha surpresa, a pintura se enquadrava 
perfeitamente nos critérios usados por este trabalho para selecionar as obras que seriam aqui analisadas: uma tela de pôr do sol produzida no período em que Vincent viveu em Arles. Para o diretor do Museu Van Gogh, Axel Rüger, esta foi a maior descoberta da história da instituição. Em declaração dada na ocasião do anúncio, ele destacou a raridade da ocorrência:

Já é uma raridade que uma nova pintura possa ser acrescentada à obra de Van Gogh. Mas o que faz este evento ainda mais excepcional é que este é um trabalho de transição em sua obra, e mais do que isso, uma pintura grande de um período que é considerado por muitos como o ponto culminante de sua conquista artística, seu período em Arles, no sul da França. Durante esse tempo, ele também pintou muitos trabalhos mundialmente famosos, como os Girassóis, A casa amarela e O quarto. A atribuição a Van Gogh é baseada em uma pesquisa extensiva sobre estilo, técnica, tinta, tela, representação, as cartas de Van Gogh e a proveniência. (VAN GOGH MUSEUM, 2013)

Os pesquisadores responsáveis por determinar a autenticidade do quadro, Louis van Tilborgh, Teio Meenderdorp e Oda Van Maanen publicaram os detalhes do processo de validação na revista britânica de arte "The Burlington Magazine", em outubro de 2013. Para eles, com esse trabalho, Vincent queria se apresentar como um poeta entre os pintores de paisagem e ficou profundamente desapontado quando sentiu que não conseguiu resolver certos problemas de forma convincente.

Foi possível determinar a autoria do quadro, segundo os autores do artigo, pela presença de diversas características típicas dos trabalhos de Van Gogh:

A mão de Van Gogh pode ser reconhecida na diversidade das pinceladas e na cremosidade da tinta, bem como na rapidez e vivacidade com que ela foi aplicada. Existem muitos detalhes característicos. Por exemplo, o traço em zigue-zague alegremente pintado para a árvore alta que quase atinge a parte superior da imagem, os traços retos para os pequenos arbustos e touceiras, e os troncos sinuosamente apresentados das azinheiras também são encontrados em "As rochas", enquanto que os traços curtos para as folhas das árvores no horizonte são quase idênticos aos de "O jardim público" ("O jardim do poeta"). E, como de costume, Van Gogh usou uma de suas pinceladas mais amplas para o céu. (TILBORGH, MEENDENDORP e VAN MAANEN, 2013)

Diferentemente das três telas anteriores, aqui o disco solar não aparece no quadro. No horizonte, do lado esquerdo da tela, podem-se ver as ruínas da Abadia de Montmajour, que fica perto de Arles. Em primeiro plano, os carvalhos "pequenos e 
retorcidos". O céu é pintado em tons de azul esverdeado, com pinceladas bem marcadas, mesmo tom escolhido para retratar o céu de Arles em várias outras telas produzidas neste verão. No campo próximo do horizonte, à distância, Van Gogh usa a cor azul, conforme descreveu em carta ao irmão.

O artista ficou absolutamente encantado com a cena que viu em julho de 1888, como podemos inferir da carta a Theo. Para ele, era uma paisagem romântica, digna do pintor Adolphe Monticelli, que admirava tanto. Quando menciona não ter ficado satisfeito com o resultado, ele pode estar se referindo ao fato de que a tela não dá a medida da beleza da "chuva de ouro" provocada pelos raios do sol sobre os arbustos e sobre a terra, que Van Gogh descreveu em sua carta.

Quando pintou essa paisagem, Vincent passava por mais um de seus períodos de melancolia, marcado pela falta de esperança em seu sucesso como artista, no descontentamento com seu trabalho e com a desilusão em relação à vinda de Gauguin. Ainda assim, é possível destacar, conforme a descrição de Tilborgh, Meendendorp e Van Maanen, a vivacidade, a rapidez e a alegria das pinceladas que compõem a tela. 
Sand barges (F 437 / JH 1570) e Sand barges (F 438 / JH 1571)

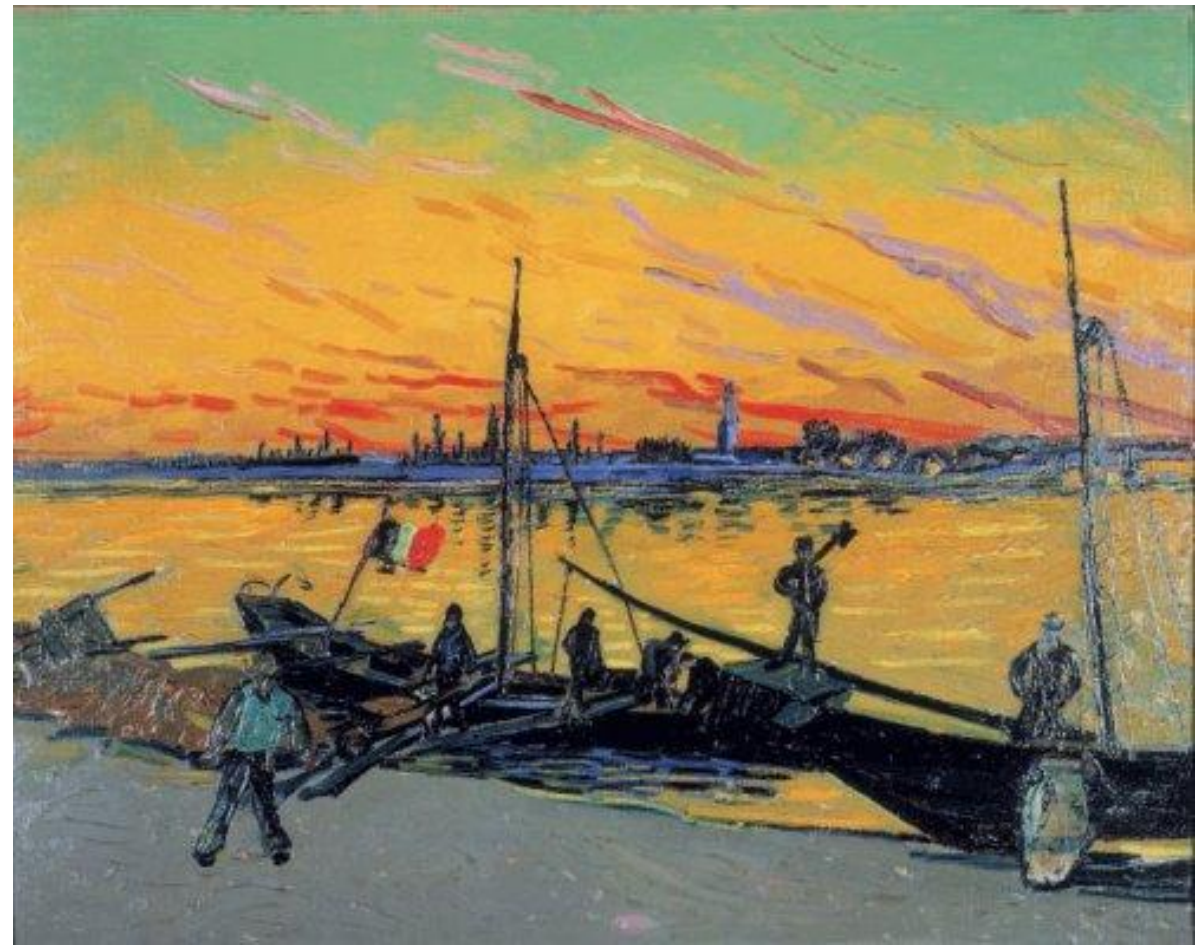

Figura 6 - Sand barges (F437 / JH 1570), outubro de 1888, óleo sobre tela - 71 x 95 cm. Coleção privada

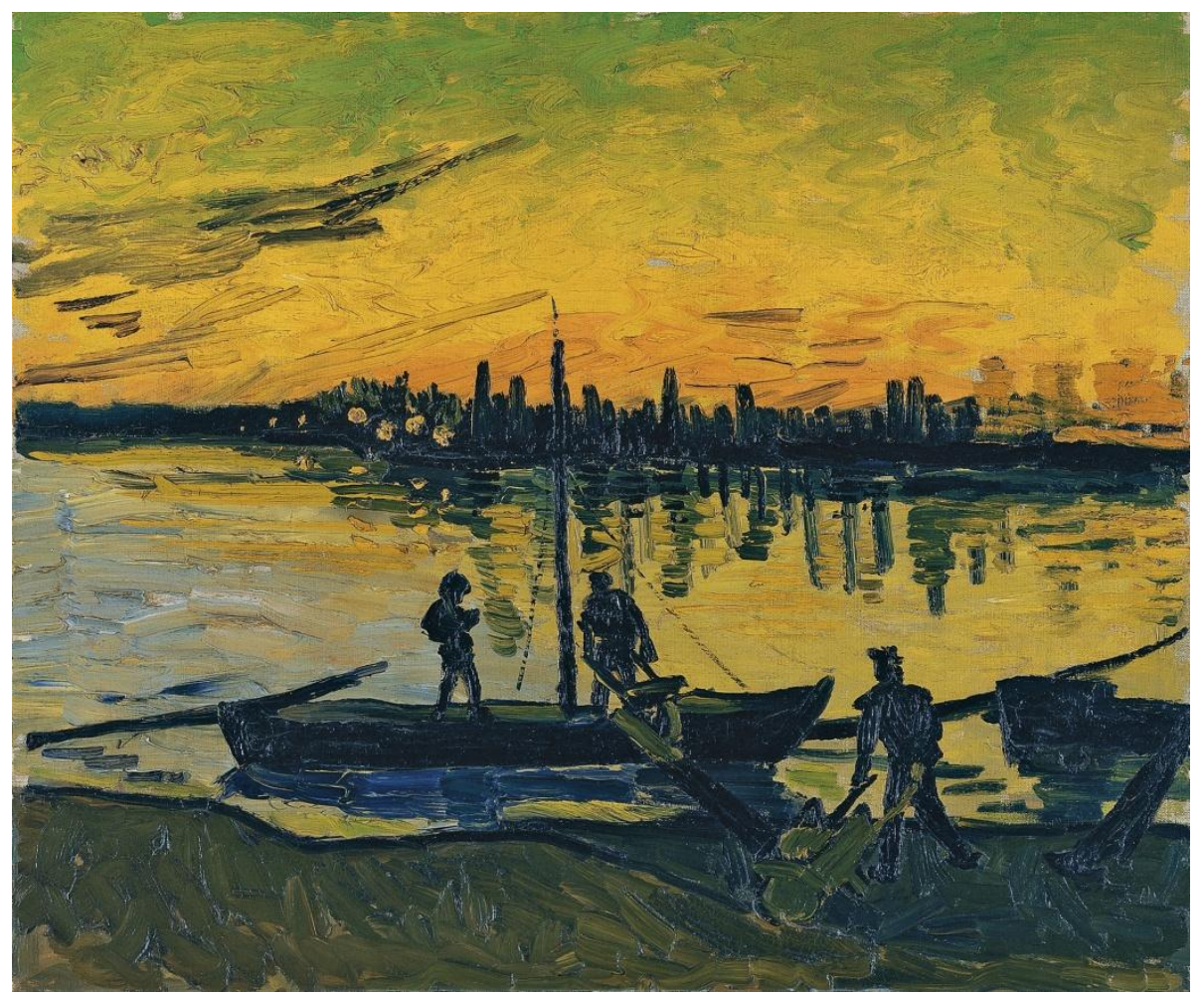

Figura 7 - Sand barges (F438 / JH 1571), outubro de 1888, óleo sobre tela - 53,3 x $64 \mathrm{~cm}$. Museu Thyssen-Bornemisza, Madri, Espanha 
No final de julho, Van Gogh descreveu, em carta para o irmão, uma cena que o encantou: dois barcos carregados de carvão ancorados no cais ao pôr do sol, com trabalhadores indo e vindo, levando a carga para a terra. Ele não pintou a cena na hora, mas posteriormente "atacou" o tema em três telas.

Eu vi um efeito magnífico e muito estranho esta noite. Um barco muito grande carregado de carvão no Ródano ancorado no cais. Visto do alto, estava tudo brilhante e molhado, a água era de um branco amarelado e cinza-pérola, o céu lilás e laranja no pôr do sol, a cidade violeta. Sobre o barco, os pequenos trabalhadores azuis e branco-sujos iam e vinham carregando a carga para a terra. Foi puro Hokusai ${ }^{15}$. Era muito tarde para fazer, mas um dia, quando voltar esse barco de carvão, ele terá de ser atacado. (Carta 652)

Conforme observam os editores das cartas, Van Gogh dividiu o tema que tanto o encantou em duas composições diferentes. Isso porque ele deve ter constatado que seria difícil pintar o barco visto de cima e, ao mesmo tempo, mostrar o pôr do sol ao fundo da cena. No quadro "Quay with sand barges", o ponto de vista é de quem observa a cena de cima. Já nas duas telas com nome de "Sand barges" (ou "Barcos de areia"), a visão do pôr do sol é privilegiada.

As duas telas aqui analisadas retratam um momento em que o sol já se escondeu no horizonte. Na primeira tela (F 437 / JH 1570), o céu laranja do fim de tarde fica entre uma faixa azul esverdeada, no canto superior da tela, e uma faixa avermelhada, perto da linha do horizonte. A cidade de Arles pode ser vista ao fundo, do outro lado do Ródano, toda azul. Em primeiro plano, dois barcos sendo descarregados. Seis trabalhadores levam areia de dentro da embarcação para a terra. Uma pequena bandeira da França está hasteada em um dos barcos. O rio é laranja como o céu, e reflete a silhueta da cidade em suas águas. A terra é cinza.

A segunda tela (F 438 / JH 1571) parece se passar em uma hora mais avançada, já no início da noite. Os barcos e os trabalhadores agora estão na penumbra e só conseguimos ver seus contornos em preto. O céu se divide entre um verde com manchas mais escuras no canto superior da tela e um laranja suave perto da linha do horizonte. A silhueta de Arles, também representada em preto em meio ao crepúsculo,

\footnotetext{
${ }^{15}$ Katsushika Hokusai (1760-1849) foi um artista japonês muito admirado por Van Gogh. Um de seus trabalhos mais conhecidos é "A Grande Onda de Kanagawa". A menção a esse artista mostra que o tema que inspirou as telas dos barcos de areia tem grande influência da arte japonesa.
} 
parece estar mais próxima do observador, com edifícios mais altos e impositivos. As águas do rio são amarelas e cinza, com a sombra dos edifícios de Arles em preto.

Entre os quadros analisados, este último é aquele em que predominam os tons mais escuros. Para mim, ele reúne aquilo que existe de mais melancólico em um pôr do sol: o fato de a luz impedir a distinção dos objetos com clareza. A luz crepuscular faz com que todos os objetos retratados na tela não passem de pinceladas negras. Os trabalhadores não têm rosto nem expressão; do outro lado do rio, Arles se parece mais com as ruínas de uma cidade fantasma; as águas do rio são opacas.

Diferentemente da avaliação dos pesquisadores do Museu Van Gogh, a análise do Museu Thyssen-Bornemisza, de Madri, que detém a tela atualmente, considera que os barcos retratados estão transportando carvão, e não areia. A instituição dá à pintura o nome de "The stevedores in Arles". Para a pesquisadora Paloma Alarcó, uma das diretoras artísticas do museu, a tela evidencia que Vincent estava se afastando dos métodos pontilhistas e impressionistas em favor de formas mais sintéticas e cores mais vivas. As pinceladas espessas e alongadas e os contrastes de cor marcantes são sinais da mudança.

"A semelhança entre a escuridão da noite e o negrume do carvão descarregado não foi coincidência. Van Gogh não se contentou apenas com as aparências, mas se esforçou para buscar significado e usou a cor para expressar certos sentimentos" (ALARCÓ). O fato de o preto aparecer de forma tão mais intensa nesta tela, portanto, pode ser significativo do sentimento que ele quis expressar.

A análise da dupla de quadros feita por Ronald Pickvance (1985) destaca que, embora os dois quadros tenham sido pintados de memória em seu estúdio, usando as mesmas pinceladas rápidas e confiantes, há diferenças substanciais em sua composição.

Como Vincent não fez nenhuma menção direta aos quadros em suas cartas - a não ser quando descreveu a cena que gostaria de pintar ao irmão, no final de julho há uma dúvida sobre a data em que as telas foram produzidas.

Quando, em uma carta escrita em 4 ou 5 de outubro, Vincent diz ao irmão "Ontem, pintei um pôr do sol", é provável que ele esteja se referindo aos barcos de areia. Porém, os pesquisadores do Museu Van Gogh não puderam determinar com certeza se é este o caso. Se essa suposição estiver correta, significa que este é o 
primeiro pôr do sol de Arles pintado em um momento em que ele relata sentir-se entusiasmado e alegre.

Esta é a época em que ele está preparando a decoração da casa amarela e se apega à missão com muito afinco, como uma das tarefas mais nobres que já desempenhou. Nas cartas deste período, é frequente a menção à importância de expressar os aspectos "ricos e magníficos" da natureza. A referência à alegria também aparece repetidas vezes entre meados de setembro e meados de outubro.

Caso as duas telas realmente datem do início de outubro, é curioso que justamente em uma época em que seu discurso se mostra tão luminoso, ele tenha se dedicado a uma pintura tão sombria quanto a segunda versão de "Sand barges". O fato de Van Van Gogh não ter mencionado as telas em suas cartas, mesmo depois de ter chamado a atenção do irmão para a beleza da paisagem que as inspirou, pode significar que o resultado não lhe agradou. Ou ele pode ter dedicado mais atenção à primeira versão dos barcos, aquela pintada do ponto de vista mais alto, esta sim tendo sido descrita em uma das cartas escritas na época. 
Red vineyard (F 495 / JH 1626)

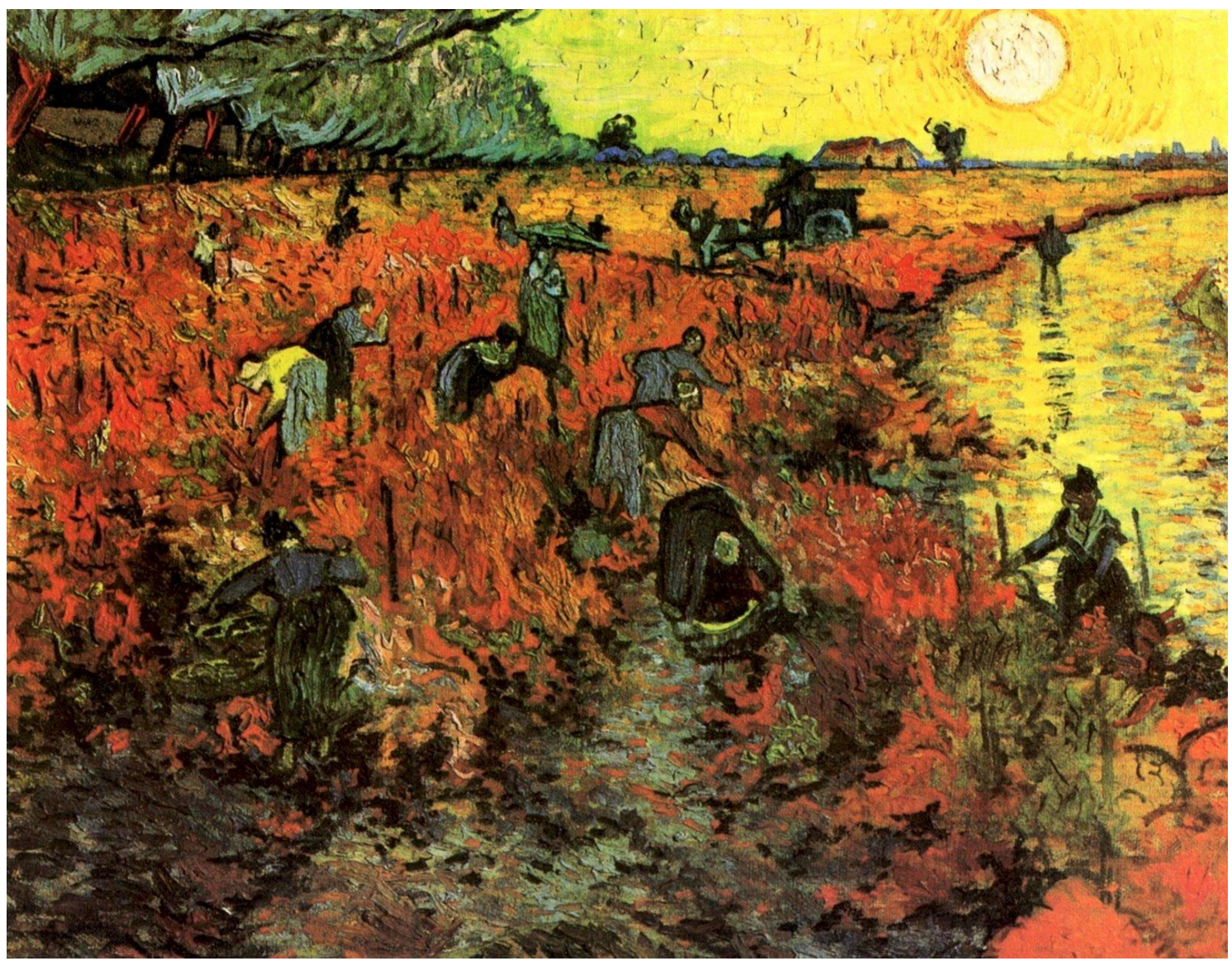

Figura 8 - Red vineyard (F495 / JH 1626), novembro de 1888, óleo sobre tela - 75 × $93 \mathrm{~cm}$. Pushkin State Museum of Fine Arts, Moscou, Rússia

"Red vineyard", ou "Vinha vermelha", tem uma peculiaridade: trata-se do único quadro que Van Gogh vendeu em vida. Ele foi comprado pela pintora belga Anna Boch, irmã do também artista Eugène Boch, que Van Gogh retratou durante sua estadia em Arles. O quadro foi comprado por 400 francos durante uma exposição em Bruxelas, apenas alguns meses antes da morte do pintor.

Ele foi inspirado em uma paisagem observada por Van Gogh durante um passeio por Arles com Gauguin:

Mas se você estivesse conosco no domingo! Nós vimos uma vinha vermelha, completamente vermelha como o vinho tinto. À distância, ela se tornava amarela e depois havia um céu verde com um sol, os terrenos depois da chuva violeta e amarelo-cintilantes aqui e lá, onde se refletia o sol se pondo. (Carta 717) 
Foi assim que Vincent descreveu a cena, em carta para Theo escrita em 3 de novembro. O quadro retrata os trabalhadores colhendo uvas em uma vinha vermelha e laranja. No canto esquerdo superior, uma fileira de árvores delimita a plantação. À direita, um caminho de terra amarelo. O horizonte, bem no alto da tela, abriga uma casa. O sol chega a encostar-se à margem superior do quadro, em meio ao céu amarelo e verde.

A mesma paisagem inspirou Gauguin a pintar uma tela completamente diferente: "Human miseries" (W317/W304). "No momento, ele está trabalhando em algumas mulheres em uma vinha, inteiramente de cabeça, mas se ele não estragar ou deixar inacabada, será muito bonito e muito estranho", diz Van Gogh sobre a pintura do amigo.

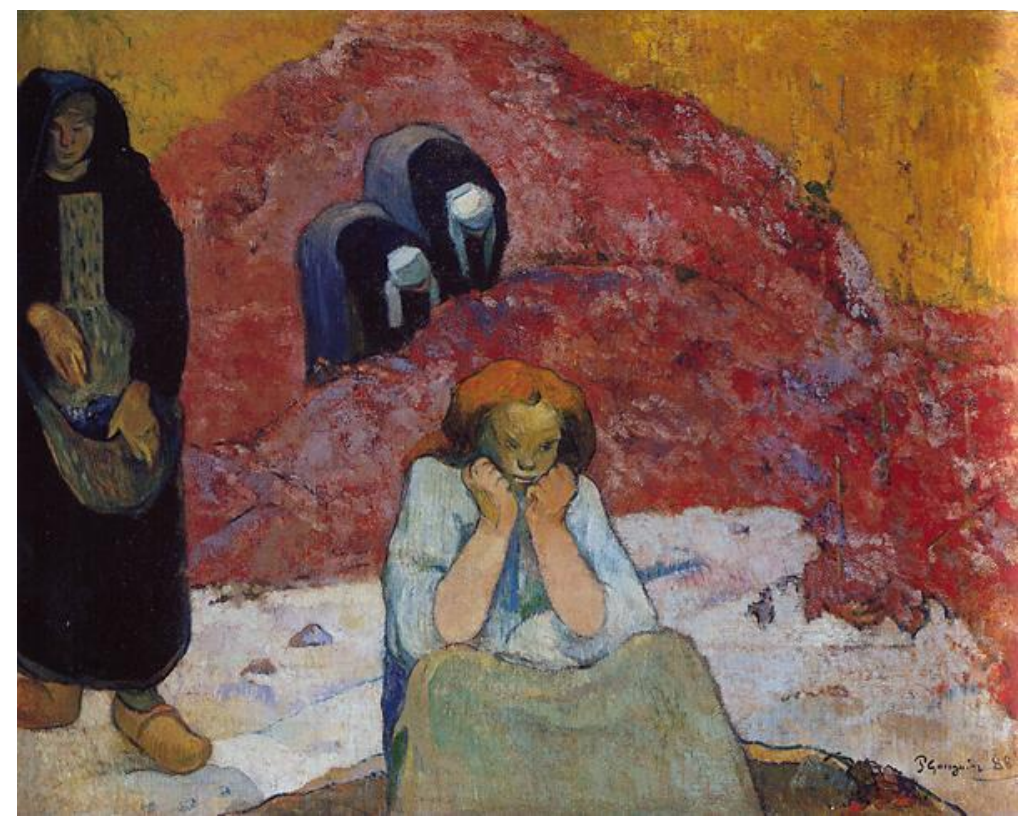

Figura 9 - Paul Gauguin, Human miseries (W317/W304), novembro de 1888, óleo sobre tela - 73,5 x $92,5 \mathrm{~cm}$. Ordrupgaard Collection, Copenhague, Dinamarca

“Ontem eu mesmo terminei uma tela de uma vinha toda púrpura e amarela com figuras azuis e violetas e um sol amarelo. Acredito que você poderá colocar essa tela perto das paisagens de Monticelli" (Carta 718), escreveu Van Gogh ao irmão, em carta de 10 de novembro.

No início de outubro, Van Gogh já havia pintado uma vinha, "The green vineyard", predominantemente verde e azul. A vinha vermelha chama a atenção pelas cores quentes e vibrantes, quebradas apenas pelo verde das árvores e pelo azul das vestes dos trabalhadores. 
Pintado no período em que Van Gogh descreve sua convivência com Gauguin como "muito feliz", este trabalho pode ser um exemplo de como a experiência do amigo impactou o modo de Van Gogh pensar suas pinturas. Diferentemente do que vinha fazendo com frequência até então, de finalizar uma tela em uma única sentada, ao ar livre, Vincent levou por volta de uma semana para concluir essa tela. Ele vinha admirando o fato de Gauguin pintar "de memória" e podia estar querendo exercitar essa habilidade.

É possível notar claramente que Van Gogh tinha passado a dedicar mais tempo em cada uma de suas telas. De acordo com os registros de Jan Hulsker, há registro de apenas 10 trabalhos de Van Gogh, entre pinturas, desenhos e esboços, concluídos em novembro (HULSKER, 1980). No mês anterior, tinham sido 23.

Se os quadros pintados anteriormente dificilmente exerciam um apelo ao público, a vinha provocou um impacto positivo nos espectadores. A tela não apenas foi a primeira do artista a ser vendida, como também despertou comentários positivos de Theo que, em junho de 1889, antes da venda do quadro, escreveu a Vincent que achava a pintura muito bonita e que, por isso, a tinha pendurado em um dos quartos de sua casa de recém-casado (Carta 781). 


\section{Sower with setting sun (F 450 / JH 1627)}

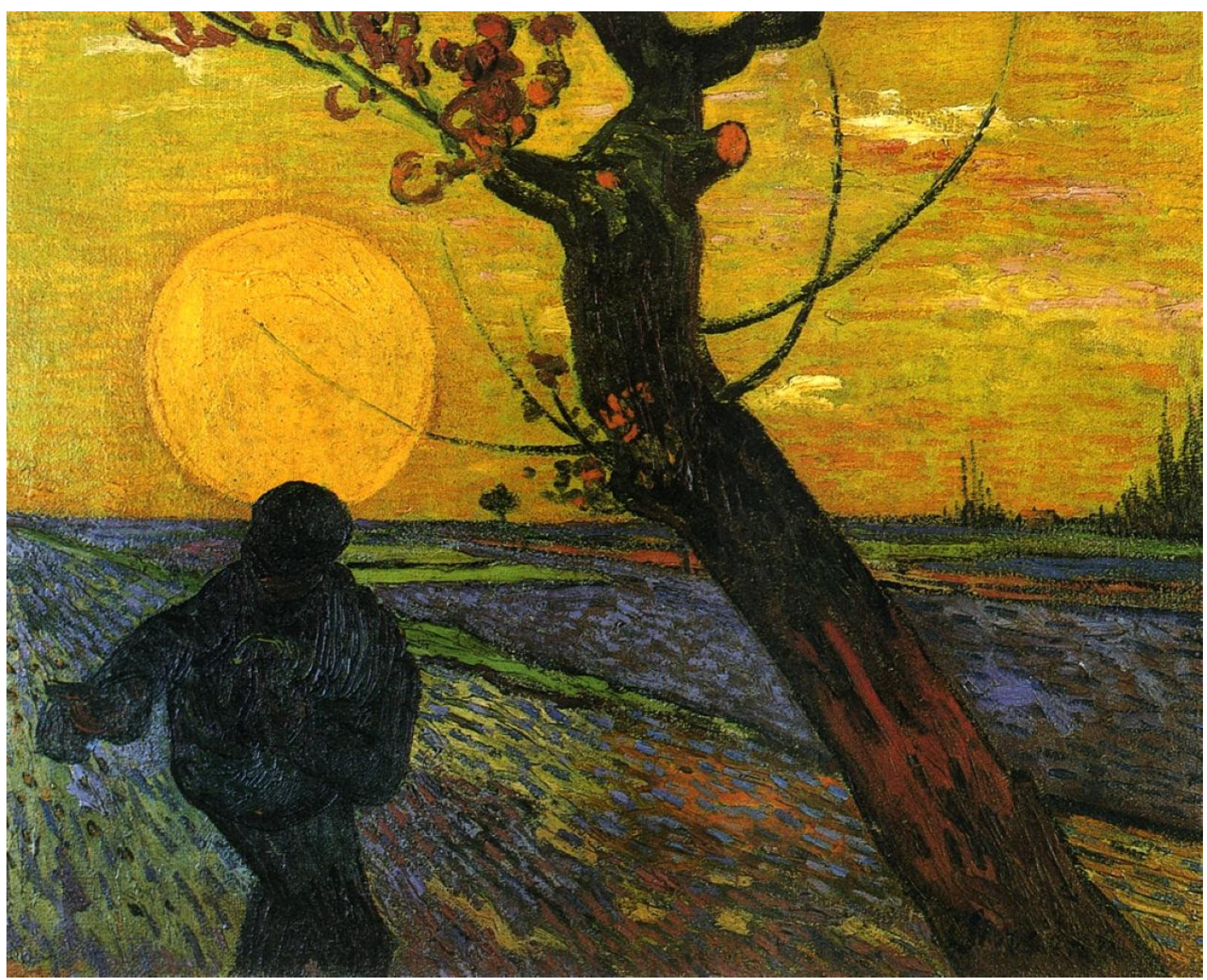

Figura 10 - Sower with setting sun (F450 / JH 1627), novembro de 1888, óleo sobre estopa sobre tela - 73,5 x 93 $\mathrm{cm}$. Foundation E. G. Buehrle Collection, Zurique, Suíça

Van Gogh começou a pintar a segunda versão do Semeador em sua primeira incursão pelo campo com Gauguin.

Mais do que qualquer outra imagem, a figura de Millet, a passos largos e ritmados, atravessando um vasto campo de terra revirada em azuis e amarelos sob uma fina faixa de céu azul-marinho, vibrava as notas consoladoras da superação da adversidade e da recompensa pela perseverança, consolo tão necessário a Vincent como contraste naquela nova provação. (NAIFEH e SMITH, 2012, p. 777)

Para Jan Hulsker, a influência japonesa deve ter sido a grande responsável pela composição "extraordinária e surpreendente" da pintura, com o semeador contra o sol poente. “A silhueta escura da árvore, que corre diagonalmente pela pintura, lembra a 
estampa de Hiroshige ${ }^{16}$, com a ameixeira inclinada que Vincent tinha copiado em Paris no ano anterior." (HULSKER, 1980, p. 374)

De fato, a influência das estampas japonesas é marcante neste trabalho, especialmente nos contornos fortes, nos contrastes de cores e no enquadramento da composição.

Como na segunda versão de "Sand barges", aqui a contraluz também não permite que vejamos com clareza os detalhes do semeador. Ele e a árvore, em primeiro plano, são compostos por pinceladas mais escuras, mas os tons vibrantes do resto da tela predominam sobre o preto.

Para H.R. Graetz (1963), na tela, o personagem semeia a "imagem da humanidade" em um movimento acolhedor. E a árvore - que se apresenta como um símbolo de luta, curvada, mas forte e maciça e com galhos apontando para o céu - é como um duplo do semeador.

O sol em brilhante amarelo escaldante e o semeador, violeta-verde escuro, se encontram no nível do horizonte. A árvore poderosa se inclina em direção do semeador e do sol e galho pontiagudo, se estendendo sobre o disco solar, acentua a contraste. O contorno do sol e a linha do horizonte parecem seguir através da cabeça do semeador. As três concepções - o sol como símbolo de luz e a mor, a árvore simbolizando a luta, e o horizonte como uma linha da vida - foram todas retratadas juntas ao semeador na pintura anterior e nos esboços. (GRAETZ, 1963, p. 128)

Para Graetz, a mudança na composição dos mesmos símbolos mostra que eles não são apenas itens casuais em um plano de fundo estático, mas elementos vivos em um movimento contínuo que atinge um auge nesta pintura intensa. "O horizonte, a infinita fronteira de terra e céu, e o sol iluminador estão centrados como se focados na cabeça do semeador, causando um impacto dinâmico de simultâneos contraste e união da natureza e do homem."

“Aqui está o croqui da última tela em que estou trabalhando, outro semeador. Imenso disco amarelo-limão como sol. Céu verde-amarelo com nuvens rosa. O campo

\footnotetext{
${ }^{16}$ Utagawa Hiroshige (1797-1858) foi um artista japonês que Van Gogh admirava. Enquanto esteve em Paris, Vincent pintou duas telas inspiradas em gravuras de Hiroshige: "The bridge in the rain" e "Flowering plum tree", a que Hulsker se refere em seu comentário.
} 
é violeta, o semeador e a árvore, azul da prússia. Tela número 30" (Carta 722). Foi assim que Van Gogh descreveu a tela, em carta a Theo de 21 de novembro.

O fato de ele ter voltado ao tema do semeador é significativo, segundo Pickvance: "Van Gogh escreveu muito sobre a gênese e a execução do semeador, evocando a seu sujeito todas as ideias, emoções, lembranças e símbolos que se ligaram a ele. Esta imagem da fecundidade é uma das mais assombrosas de toda sua obra" (PICKVANCE, 1985, p. 102).

Este segundo semeador parece ter deixado Van Gogh especialmente satisfeito. Hulsker observa que ele fez uma pequena réplica dele em meados de dezembro. Em carta escrita ao irmão em 1ㅇ de dezembro, ele disse: "De tempos em tempos, há uma tela que faz uma pintura, como a do semeador, que eu também penso que é melhor do que a primeira" (Carta 723).

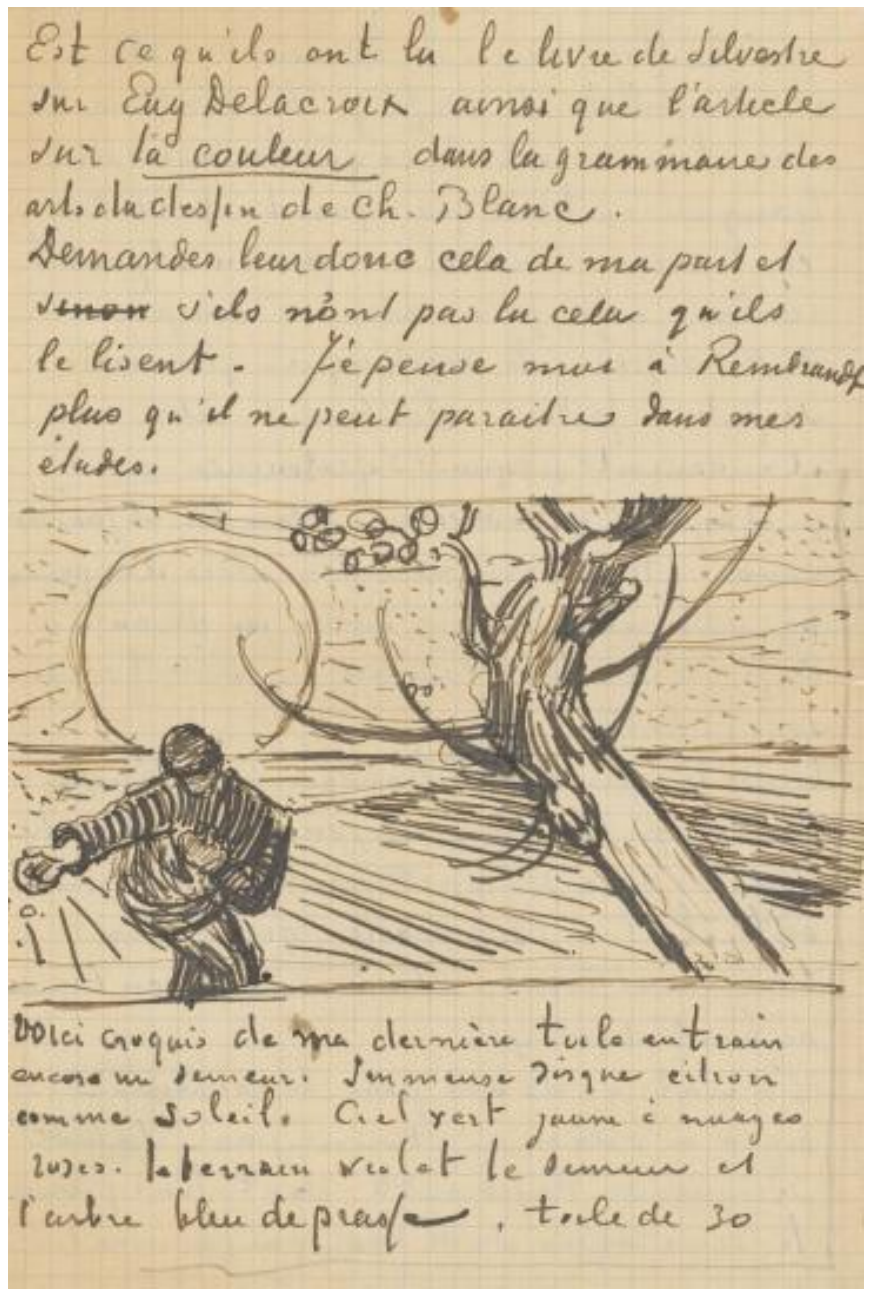

Figura 11 - Fac-símile da carta 722, escrita para Theo em 21 de novembro de 1888, com esboço da pintura Sower with setting sun 


\title{
4 Discussão
}

Tendo observado de perto cada uma das obras selecionadas para compor a análise deste trabalho - com o objetivo geral de verificar se o sentimento de melancolia experimentado por Van Gogh teve algum impacto em sua produção artística - cabe dar um passo para trás para observar a questão de um ponto de vista mais geral. Neste capítulo final, apresento uma discussão sobre as perguntas que representam os principais objetivos deste trabalho: se o estado de melancolia impulsiona seu trabalho como artista, se a melancolia imprime características específicas em sua obra e se a arte proporciona a Van Gogh um alívio ou um agravamento de seu estado melancólico.

\section{A melancolia impulsiona ou inibe sua produção?}

\begin{abstract}
Mas encontramo-nos agora diante deste enigma: haveria várias melancolias para que uns a sofram e outros a fecundem? Poderíamos falar de uma sublimação da melancolia? E, se o admitirmos, poderíamos falar de produções propriamente melancólicas? (LAMBOTTE, 2000, p. 57)
\end{abstract}

Será o melancólico de nossa clínica cotidiana capaz de sublimar uma parte do "estado violento de desejo" que se apodera dele no ciclo maníaco? Seremos nós, analistas, capazes de escutar as intensas expressões de alívio daquele que se vê provisoriamente liberado da batalha inconsciente em torno do objeto amado/odiado, de modo a permitir que ele dê à sua excitação algum destino que construa outro sentido para sua falta de ser? (KEHL, 2013, p. 31)

São estes os questionamentos que guiam essa reflexão. Em primeiro lugar, para verificar se as crises de melancolia afetaram de alguma forma a produtividade de Van Gogh - se elas, portanto, inspiravam ou inibiam o artista - cabe verificar se ele pintava com mais frequência ou menos frequência quando estava se sentindo melancólico. Para resolver essa questão, passei para a contagem das obras produzidas em cada um dos períodos delimitados por este trabalho, com base no catalogue raisonné editado por Jan Hulsker em 1980. 
É preciso reconhecer a limitação do uso deste catálogo, pois existe uma edição mais recente, publicada pelo próprio Hulsker em 1996, em que a datação das obras foi atualizada. É possível observar que algumas das informações presentes na edição de 1980 não correspondem às referências usadas pelo Museu Van Gogh. Porém, acredito que, de maneira geral, as informações podem servir como referência.

Ao longo dos dez primeiros meses em que Van Gogh viveu em Arles, entre 20 de fevereiro e 23 de dezembro, há registro de 298 trabalhos (HULSKER, 1980) produzidos por Vincent, entre pinturas, desenhos e esboços. Deste total, 201 foram feitos em períodos aqui delimitados como melancólicos - que totalizam 170 dias - e 62 foram feitos em períodos de entusiasmo - que totalizam 75 dias. Para esta conta, escolhi deixar de fora o conjunto dos trabalhos concluídos em novembro e dezembro, pois, devido à baixa frequência com que escreveu neste período, é difícil determinar com precisão a data da maioria das obras.

A frequência de produção de obras foi, portanto, maior nos períodos em que o artista se descreve como melancólico. De fato, sua fase mais produtiva coincide com uma das crises de melancolia mais longas, entre meados de junho e meados de setembro, quando conclui 132 obras em um período de 84 dias. Mas este achado é de fato significante para compreendermos o papel da melancolia na produção de Van Gogh?

Já sabemos que a relação entre a melancolia e a genialidade - inclusive no que diz respeito às artes - vem desde Aristóteles, para quem esse humor era responsável pela "criatividade do gênio" e pelo "impulso da imaginação". Essa ideia persiste até hoje, como destaca Urania Tourinho Peres:

Que a melancolia seja a condição da genialidade, do pensamento, da filosofia e da literatura é uma concepção que fascina, e muitos a defendem até os dias de hoje. Depressão e criação ficam indissociáveis; o homem triste é também o homem profundo, a alegria é superficial. (PERES, 2003)

A tristeza como uma emoção capaz de estimular o surgimento de uma humanidade criativa e combativa, condições importantes para o desenvolvimento da arte, também aparece em Kristeva: 
$\mathrm{Na}$ fronteira da animalidade e da simbolicidade, os humores - e a tristeza em particular - são as reações definitivas a nossos traumatismos, nossos recursos homeostáticos de base. Porque se é verdade que uma pessoa é escrava de seus humores, um ser afogado na tristeza, revela certas fragilidades psíquicas ou ideatórias, é igualmente verdade que uma diversificação dos humores, uma tristeza na palheta, um refinamento na dor ou no luto, são a marca de uma humanidade certamente não triunfante, mas sutil, combativa e criativa (KRISTEVA, 1987, p. 32)

O próprio Van Gogh, em sua correspondência, demonstra uma atitude ambígua em relação à questão. Se, em determinados momentos, ele se refere ao sofrimento como um elemento necessário para sua arte, em outros, essas emoções aparecem como um obstáculo a ser superado para que o artista consiga se dedicar ao trabalho.

Em uma mesma carta, escrita para Theo em 29 de julho, essas duas ideias aparecem simultaneamente. Primeiro, ele comenta o fato de seu mal estar estimulá-lo a se tornar um artista criativo: "(...) quanto mais eu me torno disperso, doente, como um jarro quebrado, eu também me torno mais um artista criativo neste grande renascimento da arte de que falamos" (Carta 650).

Em seguida, escreve sobre a importância de uma boa saúde física e mental para conseguir se dedicar ao trabalho:

Cuide de sua saúde, tome os banhos, especialmente se Gruby recomendá-los. Porque você verá, em quatro anos, o quanto eu tenho a mais do que você, como a saúde relativa é necessária para poder trabalhar. Nós que trabalhamos com a cabeça, nosso único recurso para não estarmos acabados muito rápido é o prolongamento artificial da higiene moderna rigorosamente seguida, para que possamos suportar. Porque eu, por mim mesmo, não faço nada do que deveria fazer. E um pouco de bom humor vai melhor do que o resto dos remédios. (Carta 650)

Para Freud (2013), na medida em que a melancolia se caracteriza por um desânimo profundamente doloroso e uma suspensão do interesse pelo mundo externo, ela inibe toda a atividade e torna o melancólico "incapaz para o amor e para o trabalho". É certo que, no auge das suas crises, Van Gogh menciona ter interrompido temporariamente seu trabalho ou, ao menos, refere-se à intenção de permanecer alguns dias longe dos pincéis. Mas esses intervalos não parecem ser longos. No final de outubro, por exemplo, ele promete descansar por alguns dias, por sentir que está 
prestes a ficar doente. Mas, em uma carta seguinte, conta que não conseguiu manter sua intenção.

Diante desses fatos, é possível concluir que, pelo menos no período avaliado por este trabalho, os relatos de melancolia feitos por Vincent aparecem sim relacionados a momentos de maior produtividade artística.

\section{A melancolia do artista imprime características específicas em sua obra?}

É preciso avaliar essa questão com cautela, pois Van Gogh não estabeleceu um vínculo explícito de sua obra com a melancolia, diferentemente de outros artistas, como Giorgio de Chirico, que fazia referência à melancolia no título de suas obras, ou o renascentista alemão Albrecht Dürer, cuja gravura "Melancolia I" tem sido objeto de diversas interpretações ao longo dos séculos. Em suas obras, dificilmente distinguemse símbolos universalmente relacionados à melancolia. Seus personagens não são comumente retratados nas posições clássicas do melancólico como a do anjo de Dürer, com o rosto apoiado nas mãos e o ar de enfado e desânimo.

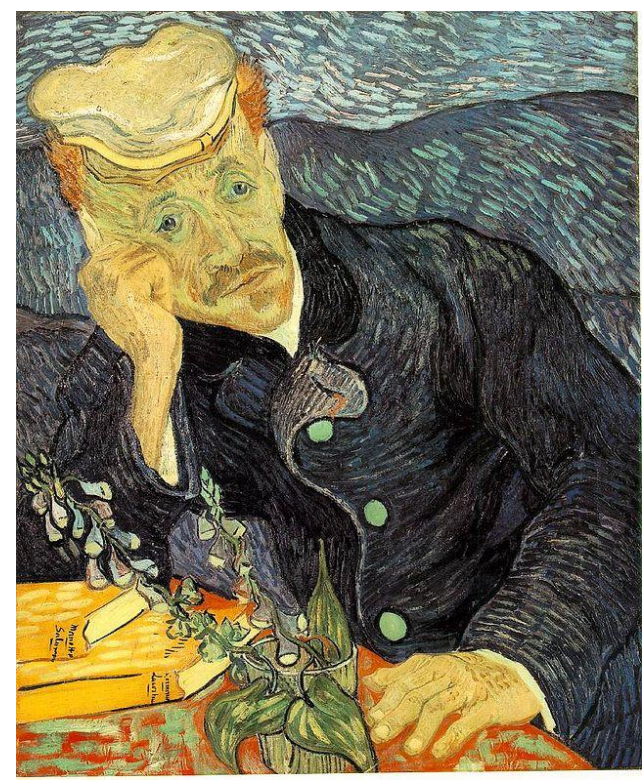

$\mathrm{cm}$. Coleção privada

Talvez uma das poucas obras em que Van Gogh tenha estabelecido ligações mais explícitas com a melancolia foi o "Retrato do Dr. Gachet" (F 753 / JH 2007), pintado em junho de 1890, em Auvers-sur-Oise, pouco tempo antes da morte do artista. "Eu fiz um retrato do Sr. Gachet com uma expressão de melancolia que pode parecer com frequência, para aqueles que olham a tela, com uma careta" (Carta 886), 
escreveu Van Gogh para a irmã Willemien. "Agora, fiz um retrato do Dr. Gachet, com a expressão desolada do nosso tempo" (Carta RM23), foi como ele descreveu o quadro para Gauguin. Para Walther, esta é a "obra-prima indiscutível na sua arte retratista".

\begin{abstract}
Melancolia, tristeza e resignação, que se podem ler no rosto de Gachet 'com a expressão desesperada do nosso tempo' penetram e determinam todo o quadro. Todas as linhas e cores condizem com esta disposição melancólica e formam uma unidade original. As linhas seguem principalmente a inclinação sorumbática da figura que atrai a disposição sensível e desencorajada deste homem. (WALTHER, 2012, p. 82)
\end{abstract}

Como Vincent via no médico alguém "mais doente" ou pelo menos "tão doente" quanto ele, havia uma forte identificação com o modelo, o que faz com que um retrato de Gachet tenha também algo de autorretrato. A expressão de melancolia do médico é, portanto, compartilhada por Van Gogh.

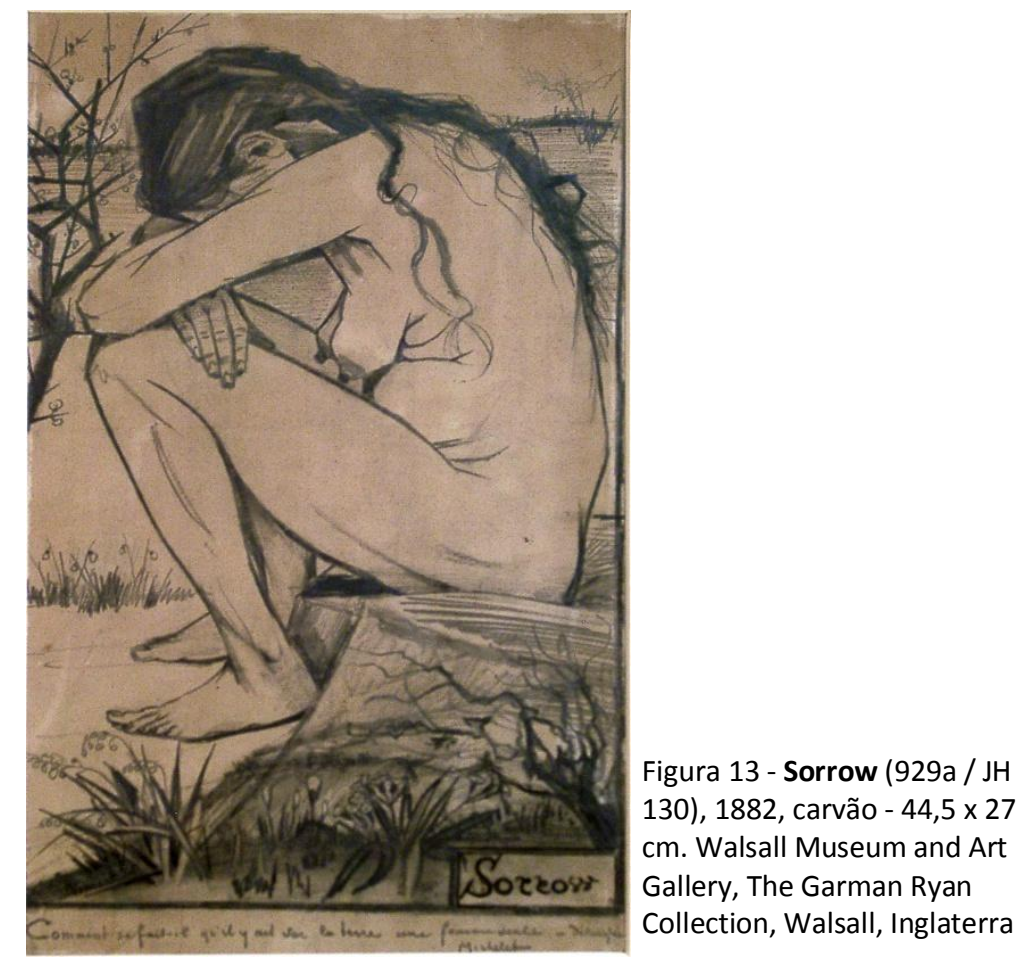

Outro exemplo de obra em que é possível estabelecer uma relação mais evidente com a melancolia é a ilustração "Sorrow" (F 929a / JH 130), feita em abril de 1882, em que a então companheira de Vincent, Sien, aparece sentada no chão, nua, grávida, com os braços apoiados no joelho e a cabeça apoiada nos braços. Sob a ilustração, Van Gogh escreveu as seguintes palavras, retiradas do livro "La Femme", de 
Jules Michelet: "Comment se fait-il y ait sur la terre une femme seule - délaissé" (Como pode haver sobre a terra uma mulher sozinha - abandonada). Sobre a ilustração, escreveu a Theo:

$E$, bem - sim, eu sei que mamãe está doente - e eu também sei de muitas outras coisas sombrias, tanto em nossa própria família quanto em outras. E eu não sou insensível a elas, e me parece que eu não conseguiria desenhar "Sorrow" se eu não as sentisse eu mesmo. (Carta 217)

Para Vincent, portanto, "Sorrow" é a representação das "coisas sombrias" que podem acometer as pessoas e que ele só tem a capacidade de pintar por ele mesmo sentir as mesmas coisas. Poses de desilusão parecidas aparecem em obras como "At eternity's gate" (F702 / JH 1967), "Peasant sitting by the fireplace" (F863 / JH34) e "Wheeping woman" (F1069 / JH 325).

Figura 14 - At Eternity's gate (F702 / JH1967), 1890, óleo sobre tela - 80 × $64 \mathrm{~cm}$. KröllerMüller Museum, Otterlo, Holanda

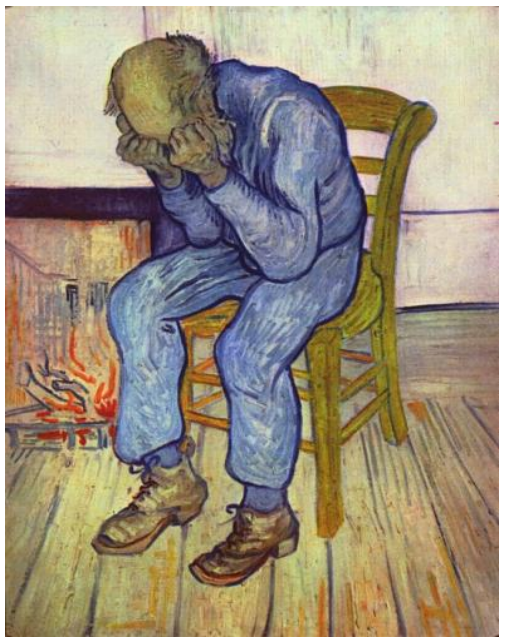

Figura 15 - Peasant sitting by the fireplace (F863 / JH34), aquarela, 1881. P. and N. de Boer Foundation, Amsterdam, Holanda

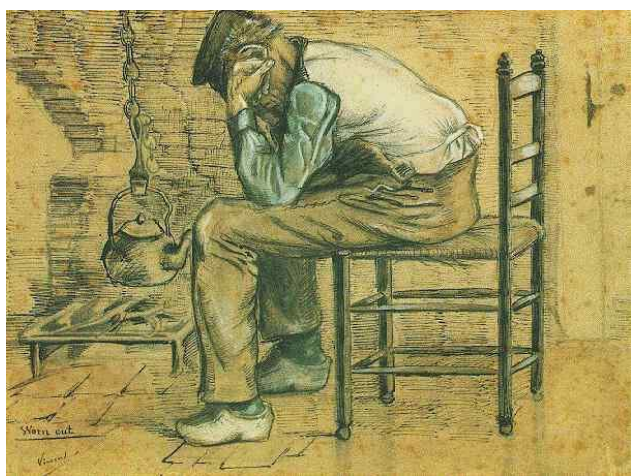

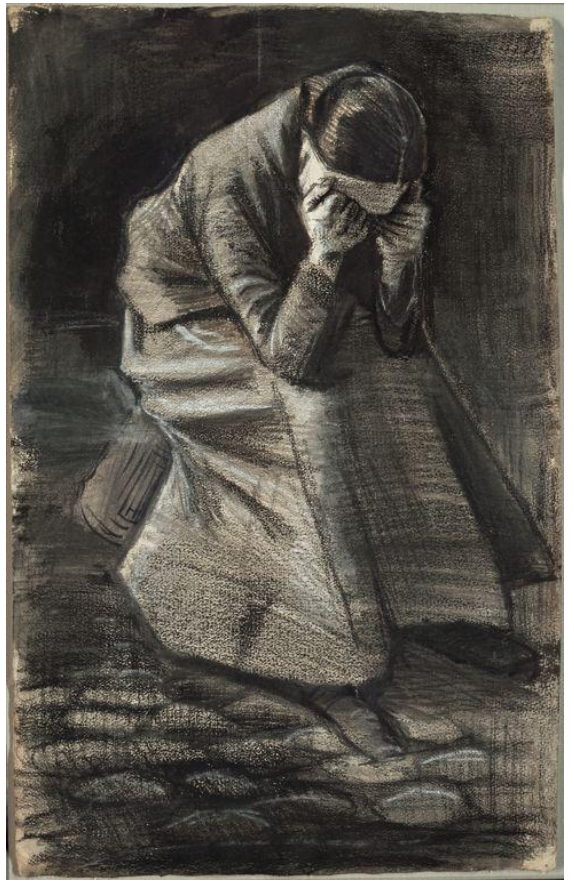

Figura 16 - Weeping woman (F1069 / JH325), giz preto e branco sobre papel, 1883, Art Institute of Chicago, Chicago, Estados Unidos 
Mas se tratam de exceções: na maioria das obras de Van Gogh, uma possível relação com a melancolia permanece oculta. É isso o que defende Sweetman (1993): "(...) quaisquer que tenham sido seus próprios sofrimentos, melancolia e depressão não são as marcas fundamentais de sua obra" (SWEETMAN, 1993, p. 10). O autor é crítico às interpretações da obra de Van Gogh que buscam identificar em suas telas símbolos incontestáveis de loucura e melancolia, enquanto o próprio artista afirmava que suas intenções eram diferentes.

Na verdade, quando se tenta olhar as pinturas com olhos e mentes não toldados pelas lendas que se acumularam em torno dele nos cem anos transcorridos desde a sua morte, é possível ver que as obras em si mesmas são gloriosamente, alegremente "sadias". Mesmo antes de morrer Vincent van Gogh foi proclamado o profeta isolado, rejeitado, da arte moderna. Em sua obra - rezava a teoria - podiam ser vistas as explosões convulsas, o colorido misterioso e enervante de uma mente obsedada. Para confirmar isso, foi preciso ignorar ou distorcer quase tudo o que o artista disse sobre suas intenções, e denegrir seu gosto pessoal em matéria de arte, pois Van Gogh foi um amante apaixonado da arte de seu tempo, uma arte agressivamente rejeitada pelos fundadores do movimento moderno. (SWEETMAN, 1993, p. 10)

Em muitos momentos de sua correspondência Van Gogh afirma, de fato, sua vontade de expressar emoções positivas, mesmo quando ele mesmo sentia o contrário. Isso aparece neste trecho da correspondência, já citado anteriormente por este trabalho:

Minha querida irmã, eu creio que atualmente é preciso pintar os aspectos ricos e magníficos da natureza, nós precisamos de alegria e de felicidade, de esperança e de amor. Quanto mais me torno feio, velho, desagradável, doente, pobre, mais eu quero me vingar fazendo a cor brilhante, bem disposta, resplandecente. (Carta 678)

Sweetman afirma, por fim, que toda tentativa de estabelecer uma conexão direta entre o homem e sua arte, em Van Gogh, deve ser avaliada com profundidade. “O Vincent que empunhara com firmeza uma pena de junco (...) não é a mesma criatura irritadiça, difícil, que partilha uma bebida com Mourier-Petersen em um dos cafés noturnos, quando o trabalho do dia está terminado" (SWEETMAN, 1993, p. 215).

A crítica em relação à tendência de interpretar a obra de Van Gogh sempre como um sintoma de sua loucura e de sua melancolia aparece também em FrayzePereira (2010). O autor cita o exemplo da análise da obra "Trigal com corvos" - 
durante muito tempo apontada como a última pintura em que Vincent trabalhou antes de sua morte - escrita pelo crítico e historiador Meyer Schapiro em 1950. Enquanto o crítico vê a obra como o símbolo da loucura do artista e como um elemento preditor do suicídio, o próprio Van Gogh, ao descrever a obra em carta ao irmão, afirma que ela exprime valores positivos, como a saúde e as forças restauradoras do campo.

Frayze-Pereira cita ainda a crítica de Schapiro sobre a obra "Noite estrelada", na qual o historiador destaca o "forte subjetivismo" de Vincent. Estudos posteriores constataram que o céu, na noite em que o quadro foi pintado, estava precisamente como Van Gogh o pintou, com todas as estrelas naquelas exatas posições, o que demonstra que, naquele caso, o pintor foi mais um realista do que um visionário. Essas informações novas mostram o quanto a interpretação de Schapiro, e também a de muitos outros críticos, é relativa.

Já na visão de Read (1983), apesar da intenção declarada de Van Gogh de expressar equilíbrio em algumas de suas obras, os esforços acabavam por não ser bem sucedidos. Ele usa o exemplo da tela "Quarto de dormir", em que a ideia era transmitir tranquilidade e descanso ao espectador, mas as fortes emoções acabaram por prevalecer:

Até o fim, ele tentaria, repetidamente, conseguir o que chamou de "um sentimento de repouso perfeito", mas repetidamente sobrepuseram-se o tormento e a agitação - as montanhas, as oliveiras, os ciprestes, o sol girando como uma roda de fogo no céu da tarde - tudo a se conformar, finalmente, ao mesmo ritmo pulsante. (READ, 1983, p. 100)

Também para Nagera, os quadros não revelam explicitamente as oscilações mentais de Vincent:

É possível assinalar algumas mudanças no estilo, no modo de manejar o pincel; há nelas indícios de uma certa urgência, de uma certa tensão, de agitação e inclusive de violência, mas a composição e a perspectiva, o manejo das cores e da disposição dos mesmos, etc., ainda que levemente modificados, não revelam de maneira perceptível sua alteração mental. É certo que, nos momentos mais graves da crise, Vincent está sem dúvida incapacitado para pintar ou não o permitem as autoridades do hospital. Sem embargo, pintou muito durante sua doença mental, sem que seu estado se evidenciasse nas obras acabadas. (NAGERA, 1980, p. 137) 
Mesmo levando em conta as ponderações de que nem tudo na obra de Van Gogh pode ser interpretado como um sinal de seu mal estar e sua melancolia, ainda assim é preciso considerar que as emoções desempenham um papel importante em sua produção. Van Gogh chegou a afirmar que, com sua obra, queria expressar emoções mais profundas do que uma "melancolia sentimental".

\begin{abstract}
Em retratos ou em paisagens, eu gostaria de expressar não algo sentimentalmente melancólico, mas uma profunda tristeza. Enfim, quero chegar ao ponto em que digam de minha obra: este homem sente profundamente, este homem sente delicadamente. Apesar de minha suposta grosseria, você me entende? Ou precisamente por causa dela. (...) O que eu sou aos olhos da maioria? Uma nulidade ou um homem excêntrico ou desagradável, alguém que não tem uma situação na sociedade ou que não a terá; enfim, pouco menos que nada. Suponho que seja exatamente assim; então, eu gostaria de mostrar por minha obra o que existe no coração de tal excêntrico, de tal nulidade. Esta é a minha ambição. (Carta 249)
\end{abstract}

Para Van Gogh, portanto, o que importava eram as emoções. Em nome das emoções, ele aceitava simplificar ou exagerar a realidade em suas obras. “(...) A simplificação e o exagero, como a cor e o trabalho do pincel, tinham de servir a alguma verdade emocional mais profunda" (NAIFEH e SMITH, 2012, p. 738). As emoções são como o filtro pelo qual a realidade passa antes de chegar às suas telas:

Vejo, porém, em meu trabalho um eco daquilo que me pareceu notável,
afinal de contas. Vejo que a natureza me disse alguma coisa, falou-me e
que anotei isso de forma resumida. Nessa anotação, pode haver palavras
não decifradas, pode haver erros ou omissões, mas há alguma coisa
daquilo que bosque, praia ou figura me disseram, e não é mais a
linguagem domesticada ou convencional de uma maneira estudada ou
de um sistema do que a da própria natureza. (Carta 260)

E, na medida em que Vincent raramente pintava quadros da imaginação e suas obras eram quase sempre baseadas em paisagens e modelos reais, a expressão das emoções ficava em boa medida por conta das cores. Naifeh e Smith (2012) observam que Vincent insistia que as combinações cromáticas corretas podiam despertar todo o leque das emoções humanas: da "angústia" das cores quebradas ao "repouso absoluto" das equilibradas; da "paixão" de vermelho e do verde ao "gentil consolo" do lilás e do amarelo. Ele rejeitava a posição cloisonista de relegar a cor a mero elemento do conjunto, e tornava-a a expressão vigorosa de "um temperamento ardente". 
Ao lermos suas cartas, podemos citar inúmeras passagens em que ele descreve a maneira como usa as cores para expressar as emoções. Dentre elas, destaco aqui uma, em que ele inclusive cita o que quer exprimir por meio de um raio de pôr do sol:

\begin{abstract}
Expressar o amor de dois amantes pelo casamento de duas cores complementares, sua mistura e suas oposições, as vibrações misteriosas de tons próximos. Expressar o pensamento de uma cabeça pelo esplendor de um tom claro sobre um fundo escuro. Exprimir a esperança por uma estrela. $\mathrm{O}$ ardor de um ser vivo pelos raios de um pôr do sol. Isto certamente não é um realismo trompe-l'oeil, mas não é alguma coisa que realmente existe? (Carta 673)
\end{abstract}

Van Gogh não fazia referência à melancolia no título de seus trabalhos, nem escolhia temas explicitamente melancólicos, à primeira vista, mas é certo que suas telas eram carregadas de emoções. $E$ as emoções sempre vinham dele, as paixões eram as suas próprias. Como observam Naifeh e Smith (2012), não importava que o objeto retratado fosse um sapato, uma cadeira, ou barcos na praia, "todas as suas janelas davam para dentro". No fundo, as telas eram sempre como autorretratos. Com uma base sólida no realismo, sendo as paisagens registradas quase sempre ao ar livre, ainda assim os olhos do artista captavam a realidade da forma que seu coração permitia.

“Paisagens, naturezas-mortas, composições - assim como a caligrafia - podem transmitir a condição interna de um ser humano", afirma Graetz (1963), em "The Symbolic Language of Vincent van Gogh". O autor defende que Van Gogh detinha o conhecimento racional sobre a forma como sua obra expressava, de forma simbólica, seus sentimentos mais profundos. Graetz justifica essa suspeita com um trecho de uma carta escrita por Vincent em 1883 para o amigo Anthon van Rappard: "A arte é algo que, apesar de produzida pelas mãos humanas, não é forjada pelas mãos sozinhas, mas brota de uma fonte mais profunda em nossa alma" (Carta 332).

Talvez Van Gogh tenha sido bem sucedido, em muitos casos, em infligir nos espectadores de seus quadros emoções quase diametralmente opostas àquelas que ele sentia no momento de pintá-los. É por isso que causa tanta estranheza o fato de observarmos resultados tão luminosos em trabalhos produzidos em momentos tão obscuros de sua vida. Porém, a melancolia sempre acaba se expressando em algum 
elemento da tela, seja em um salgueiro que remete à saudosa terra natal, em um semeador solitário ou em trabalhadores descarregando areia de um barco à contraluz.

\section{A produção artística alivia ou agrava seu estado de melancolia?}

Assim como Van Gogh demonstra uma posição ambígua sobre se a melancolia estimula ou inibe sua atividade artística, ele também expressa opiniões conflitantes sobre o impacto da arte em seu estado emocional. Em muitos momentos, ele demonstra considerar que seu trabalho é quase como uma atividade terapêutica, que o protege e o ajuda a se manter nos trilhos. Em outros, ele cita a arte como algo pelo qual sua saúde se esvaiu, como o motivo de seu desequilíbrio e a razão pela qual lhe foram negadas as glórias da "vida real".

Em algumas ocasiões, ele chega a afirmar que, por causa da arte, sua vida está em risco: "Não é mais fácil, estou convencido, fazer um bom quadro do que encontrar um diamante ou uma pérola, isso demanda esforço e nisso arriscamos nossa vida como marchand ou como artista" (Carta 691). Uma ideia semelhante aparece em outro trecho, já citado por este trabalho: “Mas, meu caro irmão, minha dívida é tão grande que quando eu a tiver pagado, o que eu acho que vou conseguir fazer, o sofrimento de produzir pinturas vai, no entanto, ter tomado toda a minha vida, e vai me parecer que eu nem vivi" (Carta 712).

Da mesma forma, há as ocasiões em que ele menciona o trabalho como uma forma de redenção. "Eu, por mim, me sinto bem aqui a esse respeito, mas aqui, já que eu tenho o trabalho e a natureza, e se eu não tivesse isso, ficaria melancólico" (Carta 611). Em outra carta, ele menciona a arte como uma distração, um prazer, um passatempo agradável: "Mas, antes, eu me sentia menos um pintor, pintar está se tornando uma distração para mim, como caçar coelhos é para as pessoas loucas que fazem isso para se distraírem. Minha atenção está se tornando mais intensa, minha mão, mais firme. E é por isso que eu ouso quase assegurar que minha pintura vai melhorar. Porque isso é tudo o que eu tenho" (Carta 645).

Na visão de Sweetman, a arte era capaz de trazer benefícios terapêuticos para Van Gogh. O autor relata o caso em que Van Gogh, em meio a uma das crises melancólicas que abateu sobre ele, resolve fazer alguns desenhos para enviar de presente para a pequena Betsy Tersteeg, filha do gerente da unidade da galeria Goupil 
em Haia, onde Van Gogh trabalhara. A atividade acaba por ajudá-lo a se distrair e a se recuperar de sua aflição:

Esses cadernos de desenho marcam o primeiro estágio de sua descoberta de que o esforço concentrado envolvido na criação de alguma coisa o ajudaria a escapar de si mesmo e se esquecer, mesmo que apenas por um breve tempo, sua inexplicável aflição. (SWEETMAN, 1993, p. 51)

Na avaliação de Naifeh e Smith (2012), no período em que viveu em Arles, Vincent passou a ver na arte uma forma de renascimento e "cura", já que tinha renunciado havia muito tempo da religião: "Como tantas vezes no passado, sobretudo em épocas de crise, ele se prendeu à possibilidade de um renascimento - de uma redenção - pela arte. Apenas a arte, disse, 'pode nos levar à criação de uma natureza mais engrandecedora e consoladora'" (NAIFEH e SMITH, 2012, p. 679). Segundo a interpretação dos autores, neste momento ele convoca uma nova visão do futuro da arte que, a exemplo de seu cristianismo, prometia transformar seus problemas em sacrifícios e seus tormentos em martírio.

De acordo com Kristeva, esse renascimento por meio da arte de fato é possível tanto pelo próprio artista quanto pelo espectador da obra de arte.

Pelo contrário, a obra de arte que assegura um renascimento de seu autor e de seu destinatário é aquela que consegue integrar na língua artificial que ela propõe (novo estilo, nova composição, imaginação surpreendente) as emoções inominadas de um eu onipotente que se faz enlutado ou órfão. Dessa forma, a ficção não é nada além de um antidepressivo, ao menos uma sobrevivência, uma ressurreição. (KRISTEVA, 1987)

Desta forma, podemos considerar que a arte conseguiu exercer, sim, o papel de redentora na vida de Vincent em alguns momentos. Porém, o excesso de comprometimento e o fervor missionário que ele demonstrava diante do trabalho, a ponto de deixar a saúde física e mental em segundo plano, podem ter contribuído para sua devastação emocional. 


\subsection{Conclusão}

A proposta inicial deste trabalho foi investigar que tipo de influência a melancolia pode ter tido sobre a obra de Van Gogh. Para isso, escolhi trabalhar com as obras de arte e as cartas produzidas nos primeiros 10 meses em que o artista viveu em Arles. A escolha levou em conta a relevância das pinturas feitas durante o período e também as evidências de que Van Gogh experimentou oscilações emocionais marcantes nesta época.

Em seguida, foi preciso definir o conceito de melancolia aqui utilizado e, para isso, voltamos até o século $V$ a.C, quando aparecem os as primeiras menções a esse termo. A evolução do conceito até a modernidade contemplou diferentes significados. Este trabalho buscou chegar o mais próximo possível daquilo que o próprio Van Gogh tinha em mente quando usava o termo melancolia para definir suas emoções.

A leitura das 139 cartas do período selecionado, bem como o contato com a obra de pesquisadores e escritores que se debruçaram sobre a trajetória do pintor permitiu constatar que a questão da melancolia era bastante presente na vida do artista. Ao identificar os momentos em que a menção e esse sentimento veio à tona em suas cartas, foi possível determinar os períodos em que ocorreram as crises melancólicas do artista. Desta forma, a observação de quadros produzidos em diferentes momentos levou à identificação de características que podem refletir esse estado de espírito.

Uma contagem dos trabalhos produzidos em cada uma dessas fases permitiu concluir que, em média, Van Gogh produziu mais trabalhos nos períodos em que ele descrevia seu temperamento como melancólico.

O próprio artista exprime, em suas cartas, ideias conflitantes sobre o papel da melancolia em seu trabalho: ora o temperamento aparece como um elemento que impulsiona a criação, ora como um obstáculo a ser vencido para que ele tenha êxito em realizar seu trabalho.

Foi possível observar que as obras não refletem de maneira óbvia os sentimentos que o artista experimentava enquanto as produzia. Em vários períodos descritos por ele próprio como melancólicos, ele criou obras perfeitamente luminosas 
e "saudáveis". De fato, vários autores alertam para os riscos de ler as obras de Van Gogh como meros sintomas de suas perturbações emocionais.

Ainda assim, pude identificar sinais desse temperamento nas obras selecionadas. O próprio Van Gogh descrevia a arte como algo que "brota de uma fonte mais profunda em nossa alma" e, com frequência, discorria sobre o modo como as cores e as pinceladas eram capazes de expressar as emoções mais profundas. É recorrente, entre seus biógrafos, a observação de que, em Van Gogh, paisagens e objetos cotidianos são como autorretratos, representando as emoções do artista.

Por fim, a atividade artística parece exercer um duplo impacto no estado mental de Van Gogh: se, por um lado, ele a vê como forma de cura e de redenção, por outro, ela aparece como o motivo pelo qual sua saúde se deteriorou. Esta última hipótese é especialmente corroborada por uma frase do bilhete encontrado no bolso de Vincent na ocasião de sua morte: "Pois bem, no meu trabalho arrisco minha vida e nele metade de minha razão naufragou". 


\section{REFERÊNCIAS}

ALARCÓ, Paloma. Thyssen-Bornemisza Collection. Museo Thyssen-Bornemisza. Disponivel em: <http://www.museothyssen.org/en/thyssen/ficha_obra/394>. Acesso em: 20 junho 2014.

ARGAN, Giulio Carlo. Arte moderna: Do lluminismo aos movimentos contemporâneos. São Paulo: Companhia das Letras, 1992.

ARISTÓTELES; PIGEAUD, Jackie. O homem de gênio e a melancolia: o problema $\mathbf{X X X , I . ~}$ Rio de Janeiro: Lacerda Editores, 1998.

ARTAUD, Antonin. Van Gogh: o suicida da sociedade. Rio de Janeiro: José Olympo, 2003.

BARBOSA, Paulo Roberto Amaral. Melancolia e questões estéticas: Giorgio De Chirico. São Paulo: ECA-USP, 2011.

BERLINCK, Luciana Chauí. Melancolia: rastros de dor e de perda. São Paulo: Humanitas, 2008.

BLUMER, Dietrich. The illness of Vincent van Gogh. American Journal of Psychiatry, Arlington, p. 519-526, Abril de 2002

BONAFOUX, Pascal. Van Gogh: El sol en la mirada. Barcelona: Blume, 2011.

BURTON, Robert. The anatomy of melancholy. Nova York: The New York Review of books, 2001.

COLI, Jorge. Vincent van Gogh: A noite estrelada. São Paulo: Brasiliense, 1985.

FOUCAULT, Michel. História da loucura na Idade Clássica. São Paulo: Perspectiva, 1978.

FRAYZE-PEREIRA, João A. O que é loucura. São Paulo: [s.n.], 1985.

Arte, dor: Inquietudes entre Estética e Psicanálise. Cotia: Ateliê Editorial, 2010. 
FREUD, Anna. Prefácio. In: NAGERA, H. Vincent van Gogh - Un studio psicológico. Barcelona: Editorial Blume, 1980.

FREUD, Sigmund. Luto e Melancolia. São Paulo: Cosac Naify, 2013.

GODOY, Luciana Bertini. Ceifar, semear: A correspondência de van Gogh. São Paulo: Annablume: Fapesp, 2002.

GRAETZ, H. R. The symbolic language of Vincent van Gogh. New York/Toronto/London: McGraw - Hill Book Company, 1963.

HULSKER, Jan. The complete Van Gogh: paintings, drawings, sketches. New York: Harrison House / Harry N. Abrams, Inc, 1980.

JANSEN, Leo; LUIJTEN, Hans; BAKKER, Nienke. Van Gogh as a letter writer - A new edition. Van Gogh Letters, 2009. Disponivel em: <http://vangoghletters.org/vg/letter_writer_1.html>. Acesso em: 20 jun. 2013.

KEHL, Maria Rita. Prefácio. In: FREUD, S. Luto e Melancolia. São Paulo: Cosak Naify, 2013.

KLIBANSKY, Raymond; PANOFSKY, Erwin; SAXL, Fritz. Saturn and melancholy: Studies of the history of natural philosophy, religion and art. Londres: Thomas Nelson and Sons Ltd., 1964.

KRISTEVA, Julia. Soleil noir: Dépression et mélancolie. Paris: Editions Gallimard, 1987.

LAMBOTTE, Marie-Claude. Estética da Melancolia. Rio de Janeiro: Companhia de Freud Editora, 2000.

LECALDANO, Paolo. Tout l'oeuvre peint de Van Gogh. Paris: Flammarion, v. 1 e 2, 1971.

NAGERA, Humberto. Vincent van Gogh - Un studio psicológico. Barcelona: Editorial Blume, 1980.

NAIFEH, Steven; SMITH, Gregory White Van Gogh: A vida. São Paulo: Companhia das Letras, 2012.

PERES, Urania Tourinho. Depressão e melancolia. Rio de Janeiro: Jorge Zahar Editor, 2003. 
PICKVANCE, Ronald. Van Gogh en Arles. Genebra: Editions d'Art Albert Skiva, 1985.

READ, Herbert. Arte e alienação: o papel do artista na sociedade. Rio de Janeiro: Zahar Editores, 1983.

SANDBLOM, Philip. Book review - Vincent van Gogh: Chemicals, Crises and Creativity. The New England Journal of Medicine, Waltham, Outubro de 1993

SWEETMAN, David. Vincent van Gogh: uma biografia. Rio de Janeiro: Jorge Zahar Editor, 1993.

TILBORGH, Louis Van; MEENDENDORP, Teio; VAN MAANEN, Oda. 'Sunset at Montmajour': a newly discovered painting by Vincent van Gogh. The Burlington Magazine, London, p. 697-705, Outubro 2013.

VAN GOGH MUSEUM. Van Gogh Museum discovers new painting by Vincent van Gogh: Sunset at Montmajour. Van Gogh Museum, 2013. Disponivel em: <http://www.vangoghmuseum.nl/vgm/index.jsp?page=330726\&lang=en $>$. Acesso em: 20 Junho 2014.

VAN GOGH, Vincent. The letters. The complete illustrated and annotated edition. Londres: Thames \& Hudson, 2009.

VAN GOGH-BONGER, Johanna. Biografia de Vincent van Gogh por sua cunhada. Porto Alegre: L\&PM, 2008.

WALTHER, Ingo F. Vincent van Gogh, 1853 - 1890: Visão e Realidade. Köln: Taschen, 2012. 